\title{
IMPLEMENTASI PERENCANAAN STRATEGIS \\ DALAM MENINGKATKAN MUTU PENDIDIKAN \\ DI SMK AL-FALAH MOGA KABUPATEN PEMALANG
}

\section{TESIS}

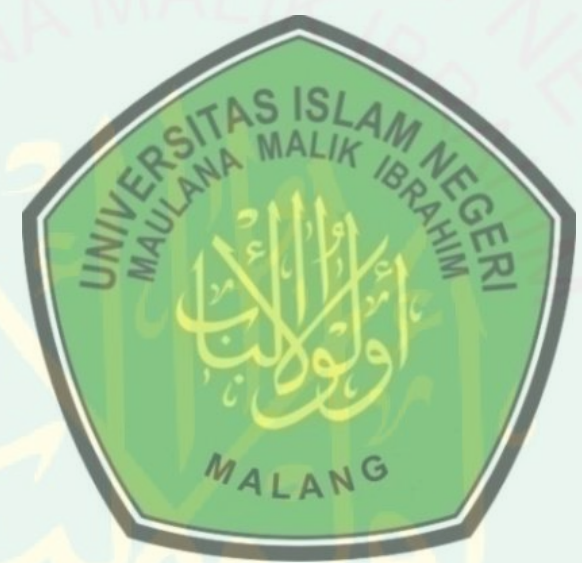

Oleh:

INSIYA AHDA SABILA

15711020

PROGRAMMAGISTER MANAJEMEN PENDIDIKAN ISLAM

PASCASARJANA

UNIVERSITAS ISLAM NEGERI MAULANA MALIK IBRAHIM

MALANG

2019 


\section{IMPLEMENTASI PERENCANAAN STRATEGIS DALAM MENINGKATKAN MUTU PENDIDIKAN \\ DI SMK AL-FALAH MOGA PEMALANG}

\section{TESIS}

\section{DiajukanKepada}

Pascasarjana Universitas Islam Negeri Maulana Malik Ibrahim Malang Untuk Memenuhi Salah Satu Persyaratan Dalam Menyelesaikan Program Magister Manajemen Pendidikan Islam

OLEH:

INSIYA AHDA SABILA

15711020

PROGRAM MAGISTER MANAJEMEN PENDIDIKAN ISLAM PASCASARJANA

UNIVESITAS ISLAM NEGERI MAULANA MALIK IBRAHIM MALANG 
LEMBAR PERSETUJUAN UJIAN TESIS

Nama

NIM

Program Studi

Judul Tesis

: Insiya Ahda Sabila
$: 15711020$

: Magister Manajemen Pendidikan Islam

: Implementasi Perencanaan Strategis dalam Meningkatkan

Mutu Pendidikan Di SMK Al-Falah Moga Pemalang

Setelah diperiksa dan dilakukan perbaikan seperlunya, Tesis dengan judul sebagaimana di atas disetujui untuk diajukan ke Sidang Ujian Tesis.

Pembimbing I

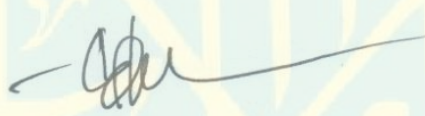

Dr. H. M. In'am Esha, M.Ag

NIP.197503102003121004
Pembimbing II

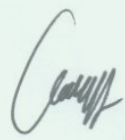

Dr. Muh. Hambali, M.Ag

NIP.19731404201411103

Mengetahui

Ketua Program Studi

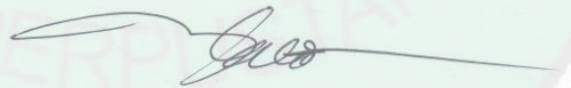

Dr. H. Wahidmurni, M.Pd, Ak

NIP. 196903032000031002 


\section{LEMBAR PENGESAHAN TESIS}

Tesis dengan judul "Implementasi Perencanaan Strategis dalam Meningkatkan Mutu Pendidikan di SMK Al-Falah Moga Kabupaten Pemalang", ini telah diuji dan dipertahankan di depan sidang dewan penguji pada tanggal 10 Juli 2018.

Dewan Penguji,

Dr. H. Ahmad Fatah Yasin, M.Ag. NIP. 196712201998031002

Dr. H. Nur Asnawi, M.Ag. NIP. 197112111999031003

Dr. H. Muhammad In'am Esha, M.A. NIP. 197503102003121004

Dr. Muh. Hambali, M.Ag. NIP. 19731404201411103

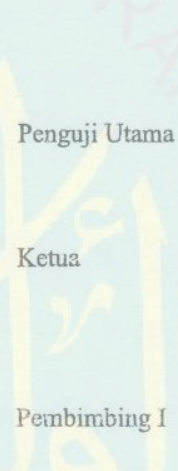

Pembimbing II
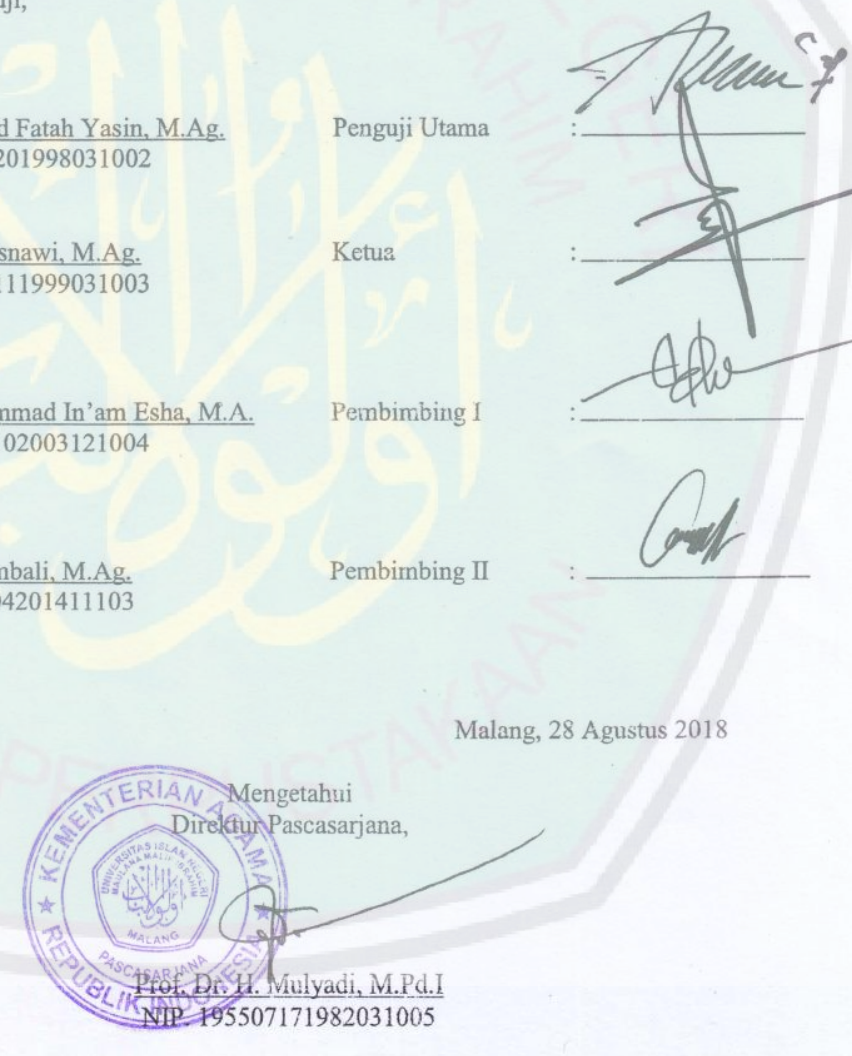


\section{SURAT PERNYATAAN ORISINALITAS PENELITIAN}

Saya yang bertandatangan di bawahini:

Nama

: INSIYA AHDA SABILA

Nim

: 15711020

Program Studi

: Magister Manajemen Pendidikan Islam

JudulPenelitian

: IMPLEMENTASI PERENCANAAN STRATEGIS

DALAM MENINGKATKAN MUTU PENDIDIKAN DI

SMK AL-FALAH MOGA PEMALANG

Menyatakan dengan sebenarnya bahwa dalam hasil penelitian saya ini tidak terdapat unsur-unsur penjiplakan karya penelitian atau karya ilmiah yang pernah dilakukan atau dibuat oleh orang lain, kecuali yang secara tertulis dikutip dalam naskah ini dan disebutkan dalam sumber kutipan dan daftar pustaka.

Apabila di kemudian hari tenyata hasil penelitian ini terbukti terdapat unsur-unsur penjiplakan dan ada klaim dari pihak lain, maka saya bersedia untuk diproses sesuai peraturan perundang-undangan yang berlaku.

Demikian surat pernyataan ini saya buat dengan sebenarnya dan tanpa paksaan dari siapapun.

Malang, Juli 2018

Hormat Saya,

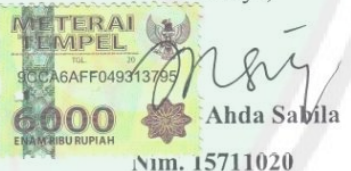

Nim. 15711020 


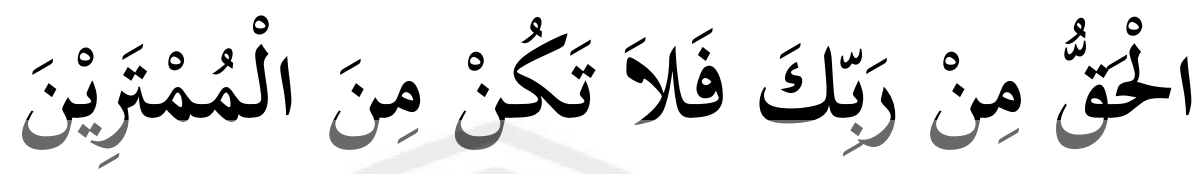

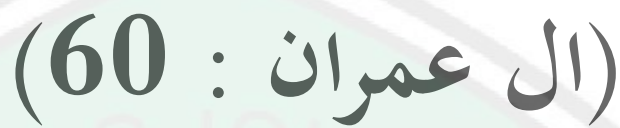

"(Apa yang telah Kami ceritakan itu), itulah yang benar, yang datang dari Tuhanmu, karena itu janganlah kamu termasuk orang-orang

yang ragu-ragu”

(Ali Imron:60) 


\section{PERSEMBAHAN}

Dengan ungkapan rasa syukur Alhamdulillah, Tesis ini dipersembahkan untuk:

1. Kedua orang tua tercinta, yang telah mencurahkan daya dan upayanya demi pendidikan anak-anaknya hingga ke jenjang Perguruan Tinggi.

2. Adikku tercinta, Zhilalul Islam dan Sayyidah Urwatil Wusqo yang selalu memberikan semangatdalam setiap hembusan nafas langkah mencari ilmu.

3. Keluarga Pondok Pesantren Al-Munawwar yang selalu memberikan semangat dan doa dalam menempuh pendidikan.

4. Sahabat MPI-A 2015, terimakasih banyak telah memberikan motivasi dan semangat, sehingga tesis ini bisa terselesaikan. 


\section{KATA PENGANTAR}

\section{Bismillahirrahmanirrahim,}

Syukur Alhamdulillah, penulis ucapkan atas limpahan rahmat dan bimbingan Allah SWT, tesis dengan judul "Implementasi Perencanaan Strategis Dalam Meningkatkan Mutu Pendidikan di SMK Al-Falah Moga Pemalang" dapat terselesaikan dengan baik, semoga ada guna dan manfaatnya. Sholawat serta salam semoga tetap terlimpahkan kepada junjungan kita nabi Muhammad SAW yang telah membimbing manusia ke arah jalan kebenaran dan kebaikan.

Banyak pihak yang membantu dalam menyelesaikan tesis ini. Untuk itu penulis sampaikan terimakasih dan penghargaan sebesar-besarnya dengan ucapan jazakumullah ahsanuljaza, khususnya kepada:

1. Rektor Universitas Islam Negeri Maulana Malik Ibrahim Malang, Bapak Prof. Dr. H. Abdul Haris, M.Ag, beserta para Wakil Rektor atas segala layanan dan fasilitas yang telah diberikan selama menempuh studi.

2. Direktur Pascasarjana Universitas Islam Negeri Maulana Malik Ibrahim Malang, Bapak Prof. Dr. H. Mulyadi, M.Pd. atas segala layanan dan fasilitas yang telah diberikan selama penulis menempuh studi.

3. Ketua jurusan Magister Manajemen Pendidikan Islam, Dr. H. Wahid Murni, M.Pd. dan sekretaris jurusan ibu Dr. Istianah Abu Bakar, M.Pd. atas layanan selama menempuh studi.

4. Dosen pembimbing I, Bapak Dr. H. M.In'am Esha,M.Ag atas bimbingan, saran, kritik, dan koreksinya dalam penulisan tesis. 
5. Dosen pembimbing II, Bapak Dr. Muh. Hambali, M.Ag. atas bimbingan, saran, kritik, dan koreksinya dalam penulisan tesis.

\section{Kepala Sekolah SMK Al-Falah Moga Pemalang, Bapak Drs. Rujito DW} beserta seluruh guru dan staff-staffnya yang telah meluangkan waktunya membantu dalam terlaksananya tesis ini.

7. Semua staff pengajar atau dosen dan semua staff tata usaha Pascasarjana Univesitas Islam Negeri Maulana Malik Ibrahim Malang yang tidak mungkin disebutkan satu persatu, yang telah banyak memberikan wawasan keilmuan dan kemudahan-kemudahan selama menyelesaikan studi.

8. Kedua orang tua, ayahanda Bapak Syaeful Hadi dan Ibunda Wulida Zunaero yang tiada henti-hentinya memberikan motivasi, bantuan materiil, dan do’a sehingga menjadi dorongan dalam menyelesaikan studi, semoga menjadi amal yang diterima di sisi Allah SWT. Amin.

Malang, Mei 2018

Penulis, 


\section{PEDOMAN TRANSLITERASI ARAB LATIN}

Penulisan trensliterasi Arab-Latin dalam Tesis ini menggunakan pedoman transliterasi berdasarkan keputusan bersama Menteri Agama RI dan Menteri Pendidikan dan Kebudayaan RI no. 158 tahun 1987 dan no.0543 b/u/1987 yang secara garis besar dapat diuraikan sebagai berikut :

A. Huruf

\begin{tabular}{|c|c|c|}
\hline $\mathrm{l}=\mathrm{a}$ & $j=z$ & ق $=q$ \\
\hline$=b$ & w s & s $=\mathrm{k}$ \\
\hline$ت=t$ & ش sy & $J=1$ \\
\hline$ث=$ ts & ص sh & $p=m$ \\
\hline$T^{=}=\mathrm{j}$ & $\dot{ض}=$ dl & $\dot{u}=n$ \\
\hline$\tau=h$ & $b=$ th & $g=W$ \\
\hline$\dot{\tau}=\mathrm{kh}$ & $\dot{b}=\mathrm{zh}$ & $\Delta=h$ \\
\hline$د=d$ & $\varepsilon=$, & $s=$, \\
\hline$\dot{j}=\mathrm{dz}$ & $\dot{\varepsilon}=g h$ & ي = y \\
\hline$ر=r$ & $\dot{\omega}=\mathrm{f}$ & \\
\hline
\end{tabular}

B. Vokal Panjang

C. Vokal Diftong

\begin{tabular}{|c|c|c|c|}
\hline Vokal (a) panjang & $=\hat{a}$ & 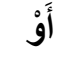 & $=$ \\
\hline Vokal (i) panjang & $=\hat{\imath}$ & أَيْي & $=$ \\
\hline Vokal (u) panjang & $=\hat{\mathrm{u}}$ & أُوْ & $=$ \\
\hline
\end{tabular}




\section{DAFTAR ISI}

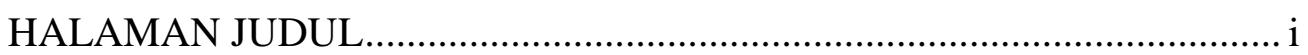

HALAMAN PERSETUJUAN ................................................................ ii

HALAMAN PENGESAHAN ................................................................... iii

HALAMAN PERNYATAAN ...................................................... iv

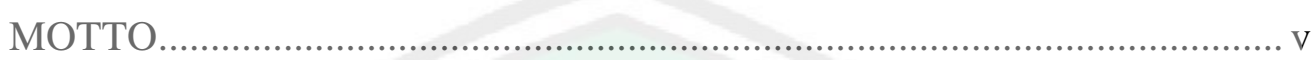

HALAMAN PERSEMBAHAN ..................................................... vi

KATA PENGANTAR ............................................................. vii

PEDOMAN TRANSLITERASI ARAB LATIN .................................. ix

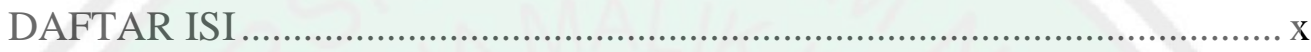

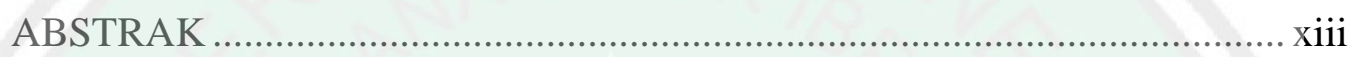

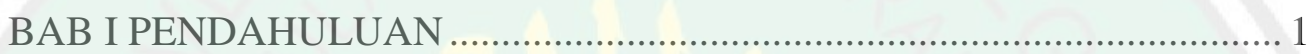

A. Konteks Penelitian ....................................................................... 1

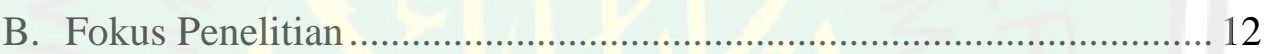

C. Tujuan Penelitian ........................................................................... 12

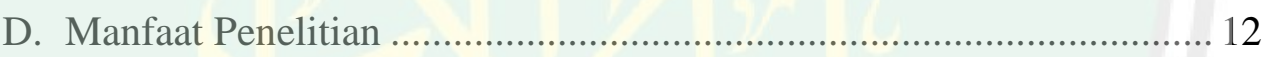

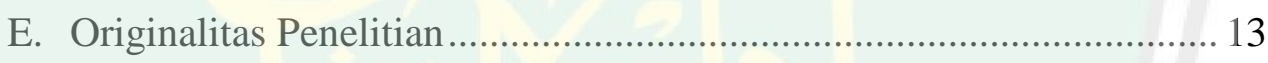

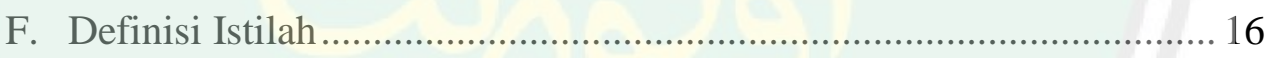

G. Sistematika Penulisan ............................................................. 17

BAB II KAJIAN PUSTAKA _................................................................ 19

A. Perencanaan Strategi .................................................................... 19

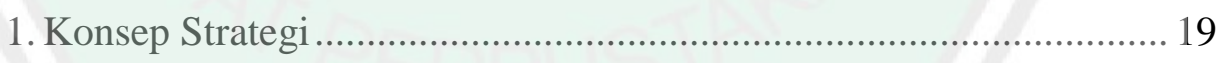

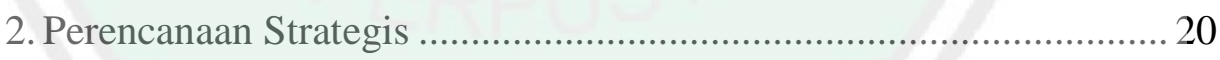

3. Karakteristik Perencanaan Strategis ................................................ 24

4. Manfaat Perencanaan Strategis ......................................................... 26

5. Proses PenyusunanPerencanaanStrategis........................................ 28

6. Pendekatan Perencanaan Strategis .................................................. 36

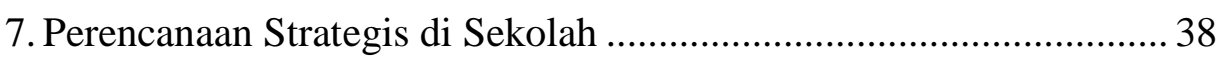

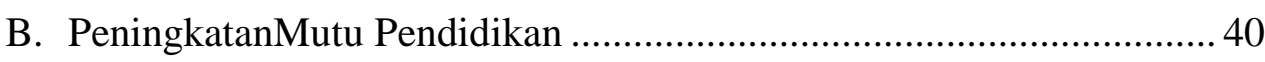

1. Pengertian Mutu Pendidikan ........................................................... 40

2. Kriteria Pencapaian Mutu Pendidikan .............................................. 42 


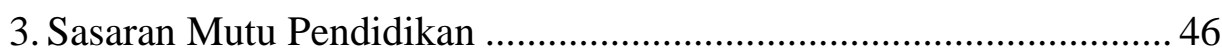

4. Faktor Pendukung dan Penghambat Mutu Pendidikan ........................ 51

5. Standar Mutu Pendidikan................................................................... 54

C. Perencanaan Strategis Peningkatan Mutu ............................................5 59

BAB III METODE PENELITIAN................................................................. 62

A. Pendekatan dan Jenis Penelitian........................................................... 62

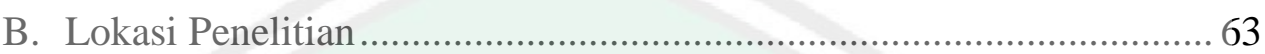

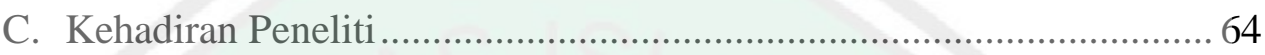

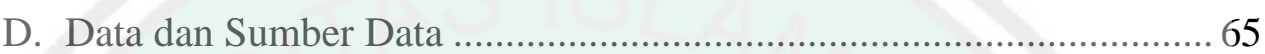

E. Tehnik Pengumpulan Data................................................................... 66

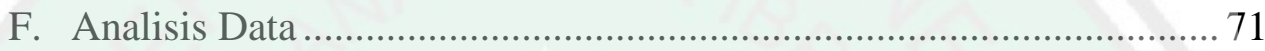

G. Pengecekan Keabsahan Temuan ...................................................... 73

BAB IV PAPARAN DATA DAN TEMUAN PENELITIAN ………………...75

A. Gambaran Umum Lokasi Penelitian .................................................. 75

1. Sejarah SMK Al-Falah Moga Pemalang............................................ 75

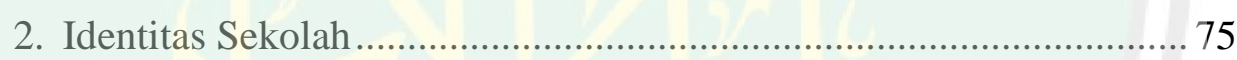

3. Visi, Misi, dan Tujuan SMK Al-Falah Moga pemalang...................... 76

4. Data Guru dan Karyawan SMK Al-Falah Moga Pemalang.................77

5. Data Siswa SMK Al-Falah Moga Pemalang ………………………... 78

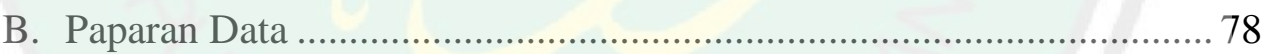

1. Proses Penyusunan Perencanaan Strategis Sekolah Dalam Meningkatkan Mutu Pendidikan di SMK Al-Falah Moga Pemalang......................... 78

2. Strategi Implementasi Perencanaan Strategis Dalam Meningkatkan Mutu Pendidikan di SMK Al-Falah Moga Pemalang …………………….... 86

3. Evaluasi dan Dampak Implementasi Perencanaan Strategis Terhadap

Mutu Pendidikan di SMK Al-Falah Moga Pemalang ......................... 92

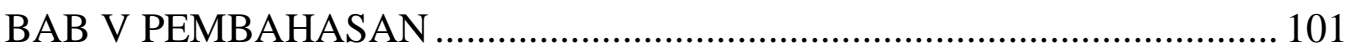

A. Proses Penyusunan Perencanaan Strategis Sekolah Dalam Meningkatkan Mutu Pendidikan di SMK Al-Falah Moga Pemalang......................... 101

B. Strategi Implementasi Perencanaan Strategis Dalam Meningkatkan Mutu

Pendidikan di SMK Al-Falah Moga Pemalang ................................. 107 
C. Evaluasi dan Dampak Implementasi Perencanaan Strategis Terhadap Mutu Pendidikan di SMK Al-Falah Moga Pemalang........................ 108

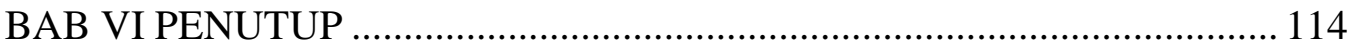

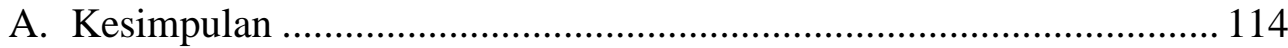

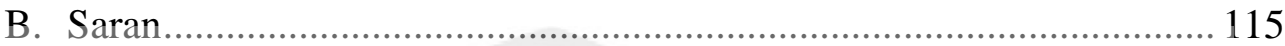

DAFTAR PUSTAKA

LAMPIRAN-LAMPIRAN 


\begin{abstract}
ABSTRAK
Sabila, Insiya Ahda. 2018. Implementasi Perencanaan Strategis Dalam Meningkatkan Mutu Pendidikan di SMK Al-Falah Moga Pemalang. Tesis, Program Pascasarjana Magister Manajemen Pendidikan Islam Universitas Islam Negeri Maulana Malik Ibrahim Malang, Pembimbing: 1) Dr. H. Muhammad In’am Esha, M.Ag; 2) Dr. Muh. Hambali, M.Ag.
\end{abstract}

Kata kunci :PerencanaanStrategisdanMutuPendidikan

Dunia pendidikan Indonesia saat ini memiliki tantangan dalam mengembangkan sekolah yang bermutu dan mencetak lulusan yang berkualitas dan berkepribadian unggul, yang memiliki daya saing baik kancah nasional maupun internasional. Dalam menyelesaikan problem ini, sekolah dapat melakukan beberapa strategi untuk meningkatkan mutu pendidikannya diantaranya yaitu dengan cara implementasi perencanaan strategis. Penelitian ini bertujuan untuk 1) menganalisis proses penyusunan perencanaan strategis, 2) menganalis strategi implementasi perencanaan strategis, 3) menganalisis evaluasi perencanaan strategis terhadap mutu pendidikan di SMK Al-Falah Moga Pemalang.

Penelitian ini adalah penelitian lapangan dengan pendekatan kualitatif jenis deskriptif, selanjutnya disebut penelitian deskriptif kualitatif dan dengan bentuk penelitian studi kasus (case study) tunggal, yaitu menyajikan uji kritis suatu teori yang difokuskan pada sebuah sekolah. Data diperoleh melalui pengamatan, dimana peneliti berfungsi sebagai instrument utama untuk melakukan observasi, wawancara mendalam dengan sumber data utama/primer dan studi dokumentasi. Data di analisis dengan analisis interaktif melalui kegiatan reduksi data, penyajian data dan penarikan kesimpulan. Pengecekan keabsahan data dilakukan dengan triangulasi sumber dan triangulasi metode.

Hasil dari penelitian ini menunjukkan bahwa: 1) proses perencanaan strategis dalam meningkatkan mutu pendidikan di SMK Al-Falah Moga Pemalang menerapkan beberapa langkah yaitu; merumuskan visi, misi, dan tujuan sekolah; membentuk satgas penyusun perencanaan strategis; proses perumusan; dan penetapan perencanaan strategis tersebut. 2) strategi implementasi perencanaan strategis dengan 2 cara yaitu; melibatkan stakeholder; dan memaksimalkan sumberdaya yang dimiliki. 3) evaluasi perencanaan strategis terhadap mutu pendidikan melalui evaluasi internal dan eksternal. Dan evaluasi program menggunakan model CIPP (context, input, process and product). 


\begin{abstract}
Sabila, Insiya Ahda. 2018. The Implementation of strategic Planning to Improve the Education Quality of SMK Al-Falah Moga Pemalang. Thesis, Postgraduate Islamic Education Management Maulana Malik Ibrahim Islamic State Uniersity. Advisors: 1) Dr. H. M. In’am Esha, M.Ag; 2) Dr. Muh Hambali, M.Ag.
\end{abstract}

Keywords: strategic planning and education quality

Indonesia's educational world currently has challenges in developing quality schools and printing quality graduates and superior personality, who have competitiveness both nationally and internationally. In solving this problem, the school can do some strategies to improve the quality of education such as by the implementation of strategic planning. The objectives of this research are 1) to analyze strategic planning process, 2) to analyze strategic plan implementation strategy, 3) to analyze evaluation of strategic planning toward education quality at SMK Al-Falah Moga Pemalang.

This research is a field research with qualitative approach of descriptive type, hereinafter referred to qualitative descriptive research and with case study research case (single case study), that presents critical test of a theory which focused on a school. Data obtained through observation, where researchers serve as the main instrument to make observations, in-depth interviews with primary data sources / documentary studies and. Data were analyzed by interactive analysis through data reduction activity, data presentation and conclusion. Data validity checking is done by source triangulation and method triangulation.

The results of this study indicate that: 1) the process of strategic planning in improving the quality of education in SMK Al-Falah Moga Pemalang apply several steps namely; formulate school vision, mission, and objectives; forming a task force for strategic planning; the process of formulation; and the establishment of such strategic planning. 2) strategic strategy implementation strategy in 2 ways; involving stakeholders; and maximize their resources. 3) evaluation of strategic planning on the quality of education through internal and external evaluation. And program evaluation uses CIPP model (context, input, process and product). 


\section{مستخلص البحث}

سبيلا، إنسيا أهدى. 2018. تنفيذ الخطة الاستراتيجية في تحسين جودة التعليم في المدرسة الثانوية المهنية الفلاح موغا بيمالانج. رسالة الماجستير، قسم أدارة التربية الإسلامية بجامعة مولانا مالك إبراهيم الإسلامية الحكومية مالنق. المشرف الأول: د. الحاج محمد إنعام أص الماجستير. المشرف الثاني: د. محمد حمبالي

الكلمات الرئيسية : الخطة الاستيراتيجية و الجودة التعليمية

يواجه عالم التعليم في إندونيسيا حاليًا تحديات في تطوير مدارس ذات جودة عالية وخريمين بيجودة الطباعة وشخصية فائقة ، تتمتع بالقدرة التنافسية على المستويين الوطني والدولي. في حل هذه المشكلة ، يمكن للمدرسة القيام ببعض الاستراتيجيات لتحسين جودة التعليم مثل تنفيذ التخطيط الاستراتيجي. أهداف هذا البحث هي 1) تحليل عملية التخطيط الاستراتيجي ، 2) لتحليل استراتيجية تنفيذ الاستراتيجية الاستراتيجية ، 3) تحليل تقييم التخطيط الاستراتيجي نغو جودة التعليم في المدرسة الثانوية المهنية الفلاح موغا بيمالانج. هذا البحث عبارة عن بحث ميداني بنهج نوعي من النوع الوصفي ، يشار إليه فيما بعد بالبحث الوصفي النوعي ومع دراسة حالة دراسة الحالة (دراسة حالة واحدة) ، والتي تقدم اختبارًا نقديًا لنظرية ركزت على مدرسة. البيانات التي تم الحصول عليها من خلال الملاحظة ، حيث يعمل الباحثون كأداة رئيسية لإجراء عمليات الرصد ، والمقابلات المتعمقة مع مصادر البيانات الأولية / الدراسات الوثائقية و. تم تحليل البيانات عن طريق التحليل التفاعلي من خلال نشاط الحد من البيانات ، وعرض البيانات والاستنتاج. يتم التحقق من صحة البيانات عن طريق تثليث المصدر وتثليث الطريقة.

تشير نتائج هذه الدراسة إلى ما يلي: 1) عملية التخطيط الاستراتيجي في تحسين جودة التعليم في المدرسة الثانوية المهنية الفلاح موغا بيمالانج. تطبيق بعض الخطوات على سبيل المثال ؛ صياغة رؤية المدرسة ورسالتها وأهدافها ؛ تشكيل فرقة عمل للتخطيط الاستراتيجي ؛ عملية صياغة وإنشاء مثل هذا التخطيط الاستراتيجي. 2) استراتيجية تنفيذ استراتيجية استراتيجية بطريقتين. إشراك أصحاب المصلحة وتعظيم مواردها. 3) تقييم التخطيط الاستراتيجي على جودة التعليم من خلال التقييم الداخلي والخارجي. ويستخدم تقييم البرنامج نموذج CIPP (السياق والمدخلات وعملية والمنتج). 


\section{BAB I}

\section{PENDAHULUAN}

\section{A. Konteks Penelitian}

Sekolah Menengah Kejuruan (SMK) Al-Falah Moga Kabupaten Pemalang merupakan sekolah yang terlahir dengan adanya program pemerintah untuk mendirikan SMK kecil/kelas jauh di pondok pesantren, yakni dibawah naungan Pondok Pesantren Al-Falah. Sesuai dengan SK Bupati Pemalang Nomor 421.5/12/2005 tentang pendirian sekolah menengah kejuruan, SMK Al-Falah Moga resmi menjadi sekolah mandiri, dengan bidang Agrobisnis Tanaman Pangan dan Holtikultura sebagai program unggulannya.Sekolah Menengah Kejuruan (SMK) Al-Falah Moga Kabupaten Pemalang juga merupakan sebuah lembaga pendidikan yang memadukan ilmu-ilmu umum yang berbasis pada kurikulum yang dikeluarkan oleh Departemen Pendidikan Nasional dan ilmu-ilmu yang berbasis pada ajaran Islam Ahlussunah Waljama'ah. Dengan pemaduan ini diharapkan bahwa alumni atau tamatan dari sekolah ini bukan hanya mempunyai keahlian, khususnya untuk memenuhi kebutuhan dunia usaha dan dunia industri (DU/DI) saja, tapi juga diharapkan mereka mempunyai bekal agama yang cukup kuat untuk bersaing di dunia nyata dengan lebih mengedepankan nilainilai agama serta akhlakul karimah. ${ }^{1}$

Salah satu standar yang telah dipenuhi dari delapan standar yang ada, dikatakan oleh Kepala Sekolah SMK Al-Falah Moga Pemalang

\footnotetext{
${ }^{1}$ Dokumentasi Profile SMK Al-Falah Moga Pemalang
} 
adalahpengelolaan sekolah. Pada Peraturan Menteri Pendidikan Nasional nomor 19 tahun 2007 tentang standar pengelolaan pendidikan oleh satuan pendidikan dasar dan menengah, mengatur bahwa setiap satuan pendidikan dasar dan menengah wajib memenuhi standar pengelolaan pendidikan yang berlaku secara nasional. Dalam menjalankan fungsi-fungsi pengelolaan, sekolah tidak boleh dibawah ataupun kurang dari standar yang telah ditetapkan baik pada perencanaan, pelaksanaan, pengawasan dan evaluasi, maupun kepemimpinan sekolah. ${ }^{2}$

Standar pengelolaan pendidikan pada sekolah yang ditetapkan oleh pemerintah, salah satu bagiannya adalah perencanaan. Dalam perencanaan ini meliputi visi, misi, dan tujuan sekolah, dan rencana kerja sekolah. Artinya setiap sekolah wajib merumuskan dan menetapkan serta mengembangkan visi, misi, tujuan, dan rencana kerja di sekolahnya sesuai dengan kriteria dan ketentuan yang telah ditetapkan tersebut. Dalam hal rencana kerja, sekolah dituntut membuat: 1) rencana kerja jangka menengah yang menggambarkan tujuan yang akan dicapai dalam kurun waktu empat tahun yang berkaitan dengan mutu lulusan yang ingin dicapai dan perbaikan komponen yang mendukung peningkatan mutu lulusan; 2) rencana kerja tahunan yang dinyatakan dalam rencana kegiatan dan anggaran sekolah (RKAS) dilaksanakan berdasarkan rencana jangka menengah. ${ }^{3}$ Melihat konteks ketentuan pemerintah yang berupa peraturan menteri pendidikan nasional tentang perencanaan tersebut, maka pada hakekatnya sekolah dituntut untuk

2 Wawancara Kepala Sekolah Bapak Rujito Dw, 16 November 2018

${ }^{3}$ Depdiknas, Permendiknas RI No 19 Th. 2007 Tentang Standar Pengelolaan Oleh Satuan Pendidikan Dasar dan Menengah (Jakarta, 2007), hlm. 3-5. 
merumuskan dan memiliki perencanaan strategis meliputi: pertama, formulasi strategis memuat visi, misi, tujuan dan rumusan program strategis empat tahunan dalam bentuk rencana kerja jangka menengah; kedua, implementasi strategis memuat program strategis tahunan berupa rencana kegiatan dan anggaran berdasarkan rencana jangka menengah.

SMK Al-Falah Moga Pemalang telah memiliki perencanaan strategis yang didalamnya memuat rencana kerja baik jangka menengah maupun tahunan. Dalam rencana induk pengembangan sekolah (RIPS) yang ada di SMK Al-Falah Moga Pemalang menurunkan rencana kebijakan sekolah yang lebih operasional menjadi program kerja sekolah dan rencana anggaran pendapatan dan belanja sekolah (RAPBS) pada tiap tahunnya, yaitu terhitung dari awal tahun ajaran sampai akhir tahun ajaran. Program kerja sekolah dan RAPBS inilah wujud dari implementasi strategis di SMK Al-Falah Moga Pemalang. ${ }^{4}$

Dengan adanya perencanaan strategis yang dimiliki SMK Al-Falah Moga Pemalang tersebut, maka mestinya sekolah mempunyai road map yang jelas untuk dijadikan pedoman bersama bagi seluruh stakeholders untuk kemajuan sekolah di masa depan. Perencanaan strategis yang merupakan hasil pemikiran strategis bersama, program-program strategis yang ada mestinya menjadi tanggung jawab bersama untuk dijalankan untuk mewujudkan visi, misi dan tujuan yang telah diputuskan.Namun demikian, menurut kepala sekolah SMK Al-Falah Moga Pemalang, perencanaan 
strategis yang ada belum dilaksanakan secara menyeluruh.Pada tingkat unitunit kerja maupun pada tiap personil yang ada di sekolah belum sepenuhnya memahami dan menjadikan perencanaan strategis sebagai panduan kerja, dan inilah yang oleh kepala sekolahnya dikatakan sebagai salah satu faktor penghambat implemetasi perencanaan strategis. ${ }^{5} \mathrm{Hal}$ inilah yang menjadi alasan peneliti tertarik untuk mengangkat permasalahan ini, yakni mengenai bagaimanakah implementasi perencanaan strategis di SMK Al-Falah Moga Pemalang ini.

Dalam mengimplementasiperencanaan strategis di sekolah, maka tiap sekolah menjalankan proses yang berupa langkah-langkah atau cara-cara tertentu agar perencanaan strategis dapat disusun secara efektif dan efisien. Tiap sekolah tentu memiliki langkah-langkah yang berbeda-beda disesuaikan dengan situasi dan kondisi yang ada disekolahnya. Sekolah akan menghasilkan sebuah perencanaan strategis yang baik apabila dalam penyusunannya menggunakan metode yang baik pula.

Perencanaan strategis di sekolah dibutuhkan sebagai bentuk usaha antisipasi terhadap perubahan atau masalah di sekolah yang perlu diselesaikan.Antisipasi masalah itu bisa sederhana dan bisa juga kompleks.Apapun masalah itu apakah sederhana atau kompleks, membutuhkan penyelesaian yang tuntas, artinya penyelesaian itu tidak setengah-setengah sehingga masalah itu tidak muncul lagi dalam waktu yang lama atau untuk selamanya. Untuk menyelesaikan antisipasi masalah ini 
membutuhkan pikiran-pikiran, analisis-analisis analisis melalui pendekatan tertentu.Dalam melakukan analisis-analisis tersebut sekolah dapat menggunakan salah satu pendekatan analisis atau beberapa model analisis.Dalam hal ini tiap sekolah juga berbeda dalam menggunakan pendekatan analisisnya.Dalam perencanaan membutuhkan pendekatan rasional kearah tujuan yang telah ditetapkan.Namun demikian, pada prinsipnya dalam perencanaan strategis harus menghasilkan sebuah analisis lingkungan strategis baik ekstenal maupun internal.Dalam perencanaan strategis yang ada di SMK Al-Falah Moga Pemalang analisis yang dilaksanakan dengan pendekatan analisis internal dan eksternal, yaitu dengan melakukan analisis lingkungan strategis secara komprehensif.Artinya analisis yang dilakukan mencakup analisis lingkungan eksternal yang terdiri dari peluang (strengths) dan ancaman (weaknesses), serta analisis lingkungan internal yang terdiri dari kekuatan (opportunities) dan kelemahan (treats).

Analisis dilakukan melalui proses intelektual yang menentukan secara sadar tindakan yang akan dilakukan dan mendasarkan keputusan-keputusan pada tujuan yang hendak dicapai, informasi yang tepat waktu dan dapat dipercaya, serta memperhatikan perkiraan keadaan yang akan datang, sehingga tergambar dengan jelas apa yang menjadi tantangan nyata bagi sekolah ke depan. Dengan adanya tantangan masa depan sekolah, maka dilahirkankan visi, misi, tujuan, dan program-program strategis yang merupakan wujud dari antisipasi dan solusi masalah yang akan datang. Sebagaimana SMK Al-Falah Moga Pemalang memiliki visi "Membangun 
sumber daya manusia beriman, bertaqwa, terampil, mandiri dan professional". Visi inilah yang menjadi wujud impian menghadapi tantangan masa depan SMK Al-Falah Moga Pemalang, yang kemudian diturunkan menjadi misi dan tujuan sekolah. Selain visi, misi, dan tujuan yang harus dijelaskan dalam perencanaan strategis, ia juga diminta memberi alasan yang rasional mengenai program yang dipilih untuk menyongsong perubahan dan menyelesaikan masalah atau mengapa suatu misi harus dipikul. Perencanaan ini dengan misinya harus juga menjelaskan kondisi tempat perencanaan itu akan dilaksanakan yaitu apa yang akan dikerjakan, siapa yang akan dilibatkan dalam pekerjaan itu, bagaimana persyaratan fasilitasnya, dan kriteria hasil yang bagaimana yang diinginkan.

Dalam manajemen strategis perencana sekaligus manajer berusaha memadukan formulasi dengan implementasi atau pikiran dengan tindakan. Perencanaan belum dianggap cukup hanya merupakan dokumentasi hasil pikiran, melainkan bagaimana proses penciptaan dokumen itu, implementasinya, pelaksanaan hasilnya di lapangan dapat diamankan dari gangguan-gangguan baik yang bersumber dari dalam lembaga pendidikan itu sendiri maupun dari luar lembaga. Implementasi perencanaan strategis dapat dilaksanakan secara efektif atau tidak bisa dilihat dengan melihat tingkat capaian dari target dan sasaran program yang telah ditetapkan. Di SMK AlFalah Moga Pemalang wujud implementasinya adalah dengan melahirkan kebijakan-kebijakan operasional dilengkapi dengan indikator pencapaian 
berikut rencana pembiayaannya yang semua itu dipadukan menjadi program kerja sekolah (PKS) dan rencana anggaran dan biaya sekolah (RAPBS).

Selain dari berbagai realitas yang melatarbelakangi lahirnya beberapa rumusan permasalahan di atas, secara umum ketertarikan peneliti adalah pada arti pentingnya implementasi perencanaan strategis bagi sebuah organisasidalam hal ini sekolah.Syarafuddin menjelaskan bahwa untuk saat sekarang ini, setiap lembaga pendidikan memerlukan adanya perencanaan strategis dengan menyusun misi, visi, tujuan, sasaran, metode, program dan kegiatan.Ia menegaskan bahwa sebagai salah satu jenis perencanaan, maka keberadaan perencanaan strategis mencakup spektrum kegiatan yang luas dan memerlukan waktu yang lama dalam mewujudkannya dan harus didukung sumber daya yang baik. Hal itu dimaksudkan sebagai perencanaan jangka panjang untuk menjawab tantangan eksternal sekolah yang semakin dinamis dan kompleks.Di sini diperlukan analisis kekuatan, kelemahan (faktor internal organisasi sekolah), dan peluang serta ancaman/tantangan (faktor ekstenal organisasi sekolah). Akhirnya akan diketahui dimana posisi sekolah, mau ke mana sekolah, dan apa masalah krusial yang dihadapi, lalu dibuatlah perencanaan strategis menjangkau masa depan yang lebih baik. ${ }^{6}$

Ditegaskan juga oleh Bryson bahwa perencanaan strategis telah didefinisikan sebagai upaya yang di disiplinkan untuk membuat keputusan dan tindakan penting yang membentuk dan mengarahkan bagaimana suatu organisasi, apa yang dikerjakan organisasi, dan mengapa melakukan apa yang 
dikerjakannya itu. Menurutnya arti penting perencanaan strategis berasal dari kemampuannya membangun organisasi secara efektif merespon lingkungan yang telah berubah secara dramatis dan kini di depannya.Ditegaskannya pula bahwa perencanaan strategis dapat membantu orgasnisasi dan komunitas untuk merumuskan dan memecahkan masalah terpenting yang mereka hadapi.Perencanaan strategis dapat membantu organisasi membangun kekuatan dan mengambil keuntungan dari peluang penting, sembari organisasi mengatasi kelemahan dan ancaman serius.Perencanaan strategis dapat membantu organisasi menjadi lebih efektif dalam dunia yang sangat bermusuhan. $^{7}$

Dalam Al-qur'an, Allah menyinggung tentang perencanaan seperti yang terdapat dalam surah Al-Hasyr ayat $18:^{8}$

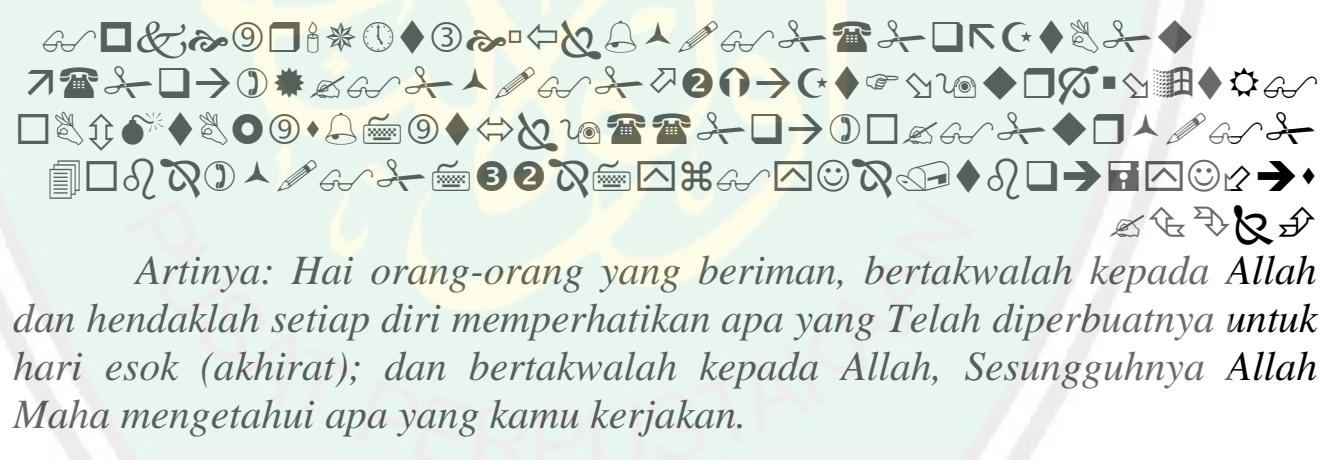

Dalam ayat tersebut Allah sebagai pencipta, Allah sebagai perencana semua makhluk ciptaannya, Allah adalah Maha Merencanakan. "Hendaklah setiap diri memperhatikan apa yang telah diperbuatnya untuk hari esok (akhirat) dalam surat tersebut," kata itu menekankan adanya perencanaan yang baik dalam diri manusia atas segala tindakan selama di dunia sehingga

${ }^{7}$ John M. Bryson, Strategic Planning For Public And Non Profit Organizations, terj. M. Miftahuddin (Yogyakarta: Pustaka Pelajar, 2001), hlm. 23-24

${ }^{8}$ Departemen Agama RI, Al-Qur'an dan Terjemahan (Bandung: Diponegoro, 2005). Hlm. 437 
ia akan mendapatkan keselamatan di akhirat nanti. Dalam setiap langkah gerak, manusia harus instrospeksi memperhatikan apa-apa yang telah diperbuatnya untuk kebaikan masa depan, dengan kata lain berarti manusia harus memiliki rencana, sehingga manusia hidupnya terarah dan tidak terjerumus ke lubang yang sama. ${ }^{9}$

Dari penjelasan tersebut dan implikasinya terhadap manajemen akan memberikan pemahaman bahwa proses perencanaan yang baik berlandaskan pendekatan Agama Islam pada Surat Al-Hasyr Ayat 18 dapat menciptakan proses menajemen yang baik (ideal). Perencanaan adalah landasan utama untuk mencapai sebuah tujuan yang baik, sehingga perencanaan yang baiklah yang akan menghasilkan tujuan yang baik.

Perencanaan sesuai yang diinginkan dalam Surat Al-Hasyr, ayat :18, mengandung enam pokok pikiran yaitu: 1. Perencanaan melibatkan proses penetapan keadaan masa depan yang diinginkan. 2. Keadaan masa depan yang diinginkan dibandingkan dengan kenyataan sekarang, sehingga dapat dilihat kesenjangannya. 3. Untuk menutup kesenjangan perlu dilakukan usaha-usaha. 4. Usaha untuk menutup kesenjangan tersebut dapat dilakukan derngan berbagai ikhtiar. 5. Perlu pemilihan alternatif yang baik, dalam hal ini mencakup efektifitas dan efesiensi. 6. Alternatif yang sudah dipilih hendaknyadiperinci sehingga dapat menjadi petunjuk dan pedoman dalam pengambilan keputusan maupun kebijaksanaan. Dengan implikasi perencanaan yang benar, maka langkah awal dari sebuah tatanan proses

${ }^{9}$ Tafsir al-Quran al-'Azhim (Darul Shidiq, jilid 4), hlm. 450. 
manajemen sudah terumus dan terarah dengan baik. Perumusan dan arah yang benar merupakan bagian yang terbesar jaminan tercapainya tujuan.

Apabila perencanaan strategis diimplementasikan secara benar dan komprehensif, tentu sebuah sekolah akan mudah meraih keberhasilannya. Tidak sedikit contoh keberhasilan dan kesuksesan dari lembaga pendidikan karena visi besar dari organisasi maupun pemimpinnya. Namun visi besar tersebut tetap realistis dengan indikator pencapaian yang jelas. Perencanaan strategis mengarahkan organisasi dan para pemimpin mengembangkan visi dalam menggambarkan masa depan yang dikehendaki. Selain visi, kemudian sekolah memiliki rumusan misi, melakukan analisis lingkungan strategis yang komprehensif, merumuskan isu-isu strategis, memiliki tujuan jangka panjang dan strategi utama, memiliki tujuan tahunan dan strategi jangka pendek sesuai dengan tujuan jangka panjang dan strategi utama yang telah ditentukan, mengimplementasikan strategi yang telah dipilih melalui alokasi sumber daya yang dianggarkan, dan mengevaluasi keberhasilan proses strategi sebagai masukan pengambilan keputusan di masa datang.Kesemuanya merupakan tahapan implementasi perencanaan strategis yang menuntun sekolah akan dapat menjawab tantangan perubahan yang begitu cepat dan kompleks serta akan meraih kemenangan dalam persaingan yang semakin ketat. Atau dengan kata lainmutu sekolah meningkat.

Joseph C. Field dalam Syafaruddin menjelaskan, "mutu diartikan sebagai ukuran dari produk atau kinerja pelayanan terhadap satu spesifikasi 
pada satu titik tertentu". ${ }^{10}$ Mutu pendidikan merupakan "kesesuaian antara kebutuhan pihak-pihak yang berkepentingan (stakeholders) dengan layanan yang diberikan oleh pengelola pendidikan". ${ }^{11}$ Dalam meningkatkan mutu, maka dikenal dengan manajemen strategis yang didalamnya terdapat perencanaan strategis.

Namun kenyataannya, unsur perencanaan pendidikan bagi sebagian sekolah masih lebih banyak dijadikan faktor pelengkap, sehingga sering kali tujuan yang telah ditetapkan tidak tercapai secara maksimal. Penyebabnya adalah karena para perencana pendidikan kurang memahami proses dan mekanisme perencanaan dalam konteks yang lebih komprehensif.Selain itu, posisi bidang perencanaan belum merupakan key factor keberadaan suatu lembaga pendidikan, baik pada tingkat makro maupun mikro.Karena itu, sumbangan perencanaan pendidikan terhadap pencapaian visi, misi, dan tujuan lembaga pendidikan belum dirasakan secara optimal.Oleh karena itu melihat berbagai kesenjangan yang ada antara realitas yang ada dengan yang semestinya terjadi, penelitian ini mengangkat judul "Implementasi Perencanaan Strategis dalam Meningkatkan Mutu Pendidikan di Sekolah Menengah Kejuruan (SMK) Al-Falah Moga Kabupaten Pemalang."

\section{B. Fokus Penelitian}

Fokus utama dalam penelitian ini adalah bagaimana implementasi perencanaan strategis dalam meningkatkan mutu pendidikan di SMK Al-

\footnotetext{
${ }^{10}$ Syafaruddin, Manajemen Mutu Terpadu dalam Pendidikan: Konsep, Strategi, dan Aplikasi.(Jakarta: PT. Gramedia Widiasarana Indonesia, 2002), hlm. 82

11 Ridwan Abdullah Sani, Isda Pramuniati, dan Anies Mucktiany, Penjamin Mutu Sekolah, (Jakarta: Bumi Aksara, 2015), hlm. 1-2
} 
Falah Moga Kabupaten Pemalang. untuk lebih jelasnya masing-masing dari fokus penelitian tersebut peneliti membuaat pertanyaan sebagai berikut:

1. Bagaimana penyusunan perencanaan strategisdalam meningkatkan mutu pendidikan di SMK Al-Falah Moga Kabupaten Pemalang?

2. Bagaimana strategiimplementasi perencanaanstrategis dalam meningkatkan mutu pendidikan diSMK Al-Falah Moga Kabupaten Pemalang?

3. Bagaimanakah evaluasi implementasiperencanaan strategi terhadap mutu pendidikandi SMK Al-Falah Moga Kabupaten Pemalang?

\section{Tujuan Penelitian}

Sesuai dengan fokus masalah tersebut diatas, maka tujuan penelitian ini adalah untuk mengetahui implementasi perencanaan strategis dalam meningkatkan mutu pendidikan di SMK Al-Falah Moga Kabupaten Pemalang. Sedangkan tujuan lebih rinci adalah sebagai berikut:

1. Untuk menganalisis penyusunan perencanaanstrategis dalam meningkatkan mutu pendidikan di SMK Al-Falah Moga Kabupaten Pemalang.

2. Untuk memahami implementasi perencanaan strategis dalam meningkatkan mutu pendidikan di SMK Al-Falah Moga Kabupaten Pemalang.

3. Untuk memahami evaluasi perencanaan strategis dalam meningkatkan mutu pendidikan di SMK Al-Falah Moga Kabupaten Pemalang. 


\section{Manfaat Penelitian}

Dari temuan hasil penelitian ini dapat dimanfaatkan untuk:

\section{Manfaat teoritis}

Manfaat teoritis dari penelitian ini adalah untuk memberikan masukan terhadap perkembangan ilmu pengetahuan dan teknologi, utamanya yang berkaitan dengan manajemen pendidikan di Indonesia.

2. Manfaat praktis

a. Dengan memahami berbagai masalah penerapan perencanaan strategis dimungkinkan bentuk pelayanan yang dilakukan oleh pihak sekolah terhadap stakeholderssemakin lebih baik.

b. Memberikan sumbanganpemikiran pentingnya penerapan perencanaan strategis pada SMK Al-Falah Moga Kabupaten Pemalang sesuai manajemen mutu sekolah dalam upaya peningkatan mutu pelayanan kepada publik.

c. Guna memperolehmasukan untuk memecahkan masalah yangdihadapi SMK Al-Falah Moga Kabupaten Pemalang, khususnya yang menyangkut kemajuan perkembangan sekolah.

\section{E. Originalitas Penelitian}

Bila mencermati beberapa literatur yang telah ada, sesungguhnya penelitian mengenai perencanaan strategis sudah ada yang meneliti. Namun dalam hal ini, peneliti mencoba mengangkat implementasi perencanaan strategis di SMK Al-Falah Moga Kabupaten Pemalang, dan penelitian ini belum pernah dilakukan oleh siapapun. Oleh sebab itu, peneliti mencoba 
memilah dari sekian literatur yang ada dan hasil penelitian mengenai perencanaan strategis untuk disesuaikan dengan tema penelitian ini.

Peneliti pertama,Khairul Umam, Perencanaan Strategis Dalam Upaya Peningkatan Mutu Lulusan di Madrasah Aliyah Negeri 1 Malang, 2007. Penelitian ini dilakukan untuk memahami bagaimana perencanaan strategis dalam upaya peningkatan mutu lulusan dilakukan. Penelitian inimenggunakan pendekatan kualitatif dengan rancangan studi kasus. Penelitian ini menghasilkan temuan tesis yaitu upaya peningkatan mutu lulusan dapat dilakukan dengan baik melalui perencanaan strategis dengan peramalan, pemrograman, pelibatan serta pengambilan keputusan yang bersifat tradisional-partisipatoris.

Kedua,Laela Tri Wahyuni, Perencanaan Strategik Madrasah Dalam Meningkatkan Mutu Pendidikan (Studi Multisitus di MTs Negeri Jabung Blitar dan MTs Negeri Gandusari Blitar), 2015. Penelitian ini bertujuan untuk menganalisis langkah-langkah perencanaan strategik dalam meningkatkan mutu pendidikan di MTsN Jabung Blitar dan MTsN Gandusari Blitar, menganalisis sasaran mutu pendidikan dalam perencanaan strategik, dan menganalisis evaluasi program peningkatan mutu pendidikan dalam perencanaan strategik di MTsN Jabung Blitar dan MTsN Gandusari. Penelitian ini menggunakan pendekatan kualitatif jenis studi kasus dengan rancangan multisitus. Hasil penelitian menunjukan bahwa konsep strategi yang lebih menekankan pada peningkatan mutululusan dan kualitas pendidik dan tenaga kependidikan. 
Ketiga, Agung Nugroho, Implementasi Perencanaan Strategis di SMK Negeri 1 Slawi Kabupaten Tegal, 2010. Penelitian ini bertujuan untuk menemukan dan mengkaji lebih mendalam tentang proses penyusunan, analisis-analisis yang digunakan, efektivitas implementasi, faktor yang mempengaruhi efektivitas implementasi dan sumbangan implementasi perencanaan strategis di SMK Negeri 1 Slawi Kabupaten Tegal. Penelitian ini menggunakan penelitian lapangan dengan pendekatan kualitatif deskriptif dengan bentuk studi kasus. Hasil penelitian ini menunjukan bahwa (1) Proses perencanaan strategis di SMK Negeri 1 Slawi Kabupaten Tegal adalah dengan: pertama, merumuskan visi, misi dan tujuan sekolah; kedua, kemudian membentuk satgas penyusun perencanaan strategis; ketiga, proses perumusan; dan keempat, penetapan perencanaan strategis tersebut.Analisis yang digunakan dalam menyusun perencanaan strategis adalah dengan menggunakan analisis SWOT (Strength, Weaknesses, Opportunities, Treats).

(3) Implementasi perencanaan strategis berjalan efektif. (4) Faktor-faktor yang memengaruhi efektivitas implementasi perencanaan strategis yaitu; kepemimpinan, pemahaman guru dan staf terhadap renstra, dukungan pemerintah, monitoring dan evaluasi, kerja sama dan tanggung jawab, dana, dan kerjasama yang baik secara internal (tim) dan eksternal. (5) Sumbangan implementasi perencanaan strategis bagi kemajuan SMK Negeri 1 Slawi yaitu: Sekolah memiliki pedoman dalam menjalankan segala aktifitasnya; Sekolah memiliki dasar kebijakan sehingga kebijakan-kebijakannya terarah; 
Memudahkan membuat program tahunan dan menentukan target-tergetnya; Sekolah menjadi berkembang secara efektif.

Tabel 1.3 Orisinilitas Penelitian

\begin{tabular}{|c|c|c|c|}
\hline Peneliti & Persamaan & Perbedaan & Orisinilitas Penelitian \\
\hline Khairul Umam & $\begin{array}{l}\text { Meneliti tentang } \\
\text { perencanaan } \\
\text { strategis }\end{array}$ & $\begin{array}{l}\text { Kajian difokuskan } \\
\text { pada implementasi } \\
\text { perencanaan strategis } \\
\text { terhadap mutu lulusan }\end{array}$ & $\begin{array}{l}\text { a. Lokasi di SMK Al-Falah } \\
\text { Moga Pemalang } \\
\text { b. Fokus proses } \\
\text { penyusunan perencanaan }\end{array}$ \\
\hline $\begin{array}{l}\text { Laela Tri } \\
\text { Wahyuni } \\
\text { (2015) }\end{array}$ & $\begin{array}{l}\text { Meneliti tentang } \\
\text { perencanaan } \\
\text { strategis }\end{array}$ & $\begin{array}{l}\text { Kajian difokuskan } \\
\text { kepada langkah- } \\
\text { langkah dan sasaran } \\
\text { mutu perencanaan } \\
\text { strategis }\end{array}$ & $\begin{array}{l}\text { strategis } \\
\text { c. Fokus pada } \\
\text { implementasi } \\
\text { perencanaan strategis } \\
\text { d. Fokus pada evaluasi }\end{array}$ \\
\hline $\begin{array}{l}\text { Agung Nugroho } \\
\qquad \text { (2008) }\end{array}$ & $\begin{array}{l}\text { Penelitian tentang } \\
\text { perencanaan } \\
\text { strategis }\end{array}$ & $\begin{array}{c}\text { Kajian difokuskan } \\
\text { pada proses } \\
\text { pelaksanaan } \\
\text { perencanaan strategis } \\
\text { sekolah }\end{array}$ & perencanaan strategis \\
\hline
\end{tabular}

\section{F. Definisi Istilah}

Dalam penelitian ini, sesuai dengan judulnya, ada beberapa istilah yang perlu didefinisikan oleh peneliti sebagai penjelasan konsep sesuai dengan yang dimaksudkan. Hal ini penting agar tidak terjadi perbedaan dan bias pemahaman konsep istilah dalam penelitian ini sehingga terjadi kesamaan persepsi. Adapun istilah yang didefinisikan adalah sebagai berikut: 
1. Perencanaan strategis merupakan proses pengambilan keputusan yang dirancang secara sistematik untuk menentukan strategi-strategi, program/arahan untuk mencapai tujuan sekolah.

2. Mutu pendidikan merupakan tingkat pencapaian pendidikan sesuai dengan kriteria dan standar yang telah ditetapkan yang mencakup input, proses dan output.

3. Implementasi perencanaan strategis dalam meningkatkan mutu pendidikan maksudnya adalah proses pengimplementasian perencanaan strategis tentang mutu pendidikan. Dalam hal ini mutu di lembaga pendidikan yang mencakup input, proses, dan outputpendidikan. Dengan demikian dapat pula diartikan bahwa perencanaan peningkatan mutu guru, karyawan, kurikulum, sarana dan prasarana, visi, misi maupun tujuan (input), serta perencanaan peningkatan mutu pengambilan keputusan dan pengelolaan kelembagaan (proses), pada akhirnya adalah demi peningkatan mutu lulusan (output).

\section{G. Sistematika Penulisan}

Untuk memberikan gambaran mengenai isi laporan penelitian ini, maka sistematika pembahasan disusun sebagai berikut:

Bab I Pendahuluan. Dalam bab ini terdapat sub pembahasan antara lain kontek penelitian, fokus penelitian, tujuan penelitian, manfaat penelitian, definisi istilah, originalitas penelitian, sistematika pembahasan. 
Bab II Pembahasan. Dalam bab ini berisikan tentang kajian teori yang didalamnya membahas tinjauan tentang konsep perencanaan strategis, mutu pendidikan menurut para ahli dan kerangka berpikir.

Bab III Metode penelitian. Dalam bab ini khusus membahas tentang metode penelitian mencakup pembahasan tentang pendekatan dan jenis penelitian, kehadiran penelitian, latar penelitian, data dan sumber data penelitian, teknik pengumpulan data, teknik analisis data dan pengecekan keabsahan data.

Bab IV Paparan Data dan Temuan Penelitian.Pada bagian ini mengemukakan hasil penelitian yang telah dilakukan dan memaparkan data yang telah ditemukan.

Bab V Pembahasan Temuan Penelitian.Pada bagian ini, hasil penelitian dianalisis untuk menjawab fokus penelitian dan tujuan penelitian.

Bab VI Penutup. Pada bagian ini memuat simpulan yang merupakan jawaban akhir dari permasalahan penelitian, dan saran yang berkaitan dengan permasalahan. 


\section{BAB II}

\section{KAJIAN PUSTAKA}

\section{A. Perencanaan Strategi}

\section{Konsep Strategi}

Kata strategi berasal dari bahasa Yunani kuno strategeia, yang berarti seni atau ilmu menjadi seorang jenderal. ${ }^{12} \mathrm{O}$ 'Toole menyebutkan strategi berasal dari kata strategi dalam bahasa Yunani yang merupakan gabungan dari stratos atau tentara dan ego atau pemimpin. Maka tidak heran bila pada awalnya istilahstrategi popular didalam kemiliteran dan selanjutnya berkembang pada ilmuekonomi perusahaan. Sejak zaman Yunani kuno, konsep strategi sudahmempunyai komponen perencanaan dan pembuatan keputusan atau komponentindakan.

David mengartikan strategi adalah alat untuk mencapai tujuan jangka panjang, merupakan tindakan potensial yang membutuhkan keputusan manajemen tingkat atas dan sumber daya perusahaan/organisasi dalam jumlah yang besar. Selain itu ditegaskannya bahwa strategi memengaruhi kemakmuran perusahaan/organisasi dalam jangka panjang dan berorientasi masa depan. ${ }^{13}$ Sedangkan Pearce dan Robin mengartikan strategi adalah rencana berskala besar, dengan orientasi masa depan, guna berinteraksi dengan kondisi persaingan untuk mencapai tujuan perusahaan/organisasi. ${ }^{14}$ Hal senada diungkapkan oleh

\footnotetext{
${ }^{12}$ James A.F. Stoner et.all, Manajemen (Jakarta: Buana Ilmu Populer, 1996), hlm. 216.

${ }^{13}$ Fred R, David, Manajemen Strategis, Edisi Sepuluh (Jakarta: Salemba Empat, 2006),hlm. 16-17 ${ }^{14}$ John A. Pearce II dan Richard B. Robinson, Jr., Manajemen Strategis-Formulasi, Implementasi dan Pengendalian (jakarta: Salemba Empat, 2008), hlm. 6.
} 
Glueck dan Jauch bahwa strategi adalah rencana yang disatukan, luas dan terintegrasi yang menghubungkan keunggulan strategis perusahaan dengan tantangan lingkungan dan yang dirancang untuk memastikan bahwa tujuan utama dari perusahaan itu dapat dicapai melalui pelaksanaan yang tepat oleh organisasi. ${ }^{15}$

Dari beberapa pengertian strategi tersebut dapat disimpulkan bahwa strategi pada dasarnya adalah sebuah perencanaan yang bersifat besar, luas, dan terintegrasi serta berorientasi masa depan sehingga sangat berpengaruh bagi kemajuan organisasidengan mempertimbangkan faktorfaktor eksternal dan internal untuk meraih tujuan organisasi.

\section{Perencanaan Strategis}

Perencanaan strategis merupakan bagian dari manajemen strategis. Manajemen strategis adalah seni dan ilmu untuk pembuatan (formulating), penerapan (implementing), dan evaluasi (evaluating) keputusan-keputusan strategis antar fungsi yang memungkinkan sebuah organisasi mencapai tujuan di masa datang. Jadi, perencanaan strategis lebih terfokus pada bagaimana manajemen puncak menentukan visi, misi, falsafah, dan strategi perusahaan untuk mencapai tujuan perusahaan dalam jangka panjang. ${ }^{16}$

Mengenai perencanaan strategis ditemukan banyak definisi, namun semuanya menurut Salusu menjawab satu pertanyaan pokok, “apa

\footnotetext{
${ }^{15}$ William F. Glueck dan Lawrence R. Jauch, Manajemen Strategis dan Kebijakan Perusahaan (Jakarta: Penerbit Erlangga, 1994), hlm. 9.

${ }^{16}$ Husein Umar, Strategic Management in Action (Jakarta: Gramedia Pustaka Utama, 2001), hlm. 17.
} 
yang akan diperbuat". Perencanaan strategis adalah instrumen kepemimpinan dan suatu proses, ia menentukan apa yang dikehendaki suatu organisasi dimasa depan dan bagaimana usaha mencapainya, "suatu proses yang menjelaskan sasaran-sasaran”. Seperti juga ditegaskan oleh Salusu bahwa perencanaan strategis sebagai komponen dari manajemen strategis bertugas untuk menjelaskan tujuan dan sasaran, memilih berbagai kebijaksanaan, terutama dalam memperoleh dan mengalokasikan sumber daya serta menciptakan suatu pedoman dalam menerjemahkan kebijaksanaan organisasi. ${ }^{17}$

Bahkan ditegaskan oleh Salusu, ada yang mengatakan bahwa perencanaan strategis adalah suatu proses dalam membuat keputusan strategis, atau yang menawarkan metode untuk memformulasikan dan menerapkan keputusan strategis serta mengalokasikan sumberdaya untuk mendukungnya di seantero unit kerja dan tingkatan dalam organisasi. Ia adalah suatu cara untuk mengembangkan konsensus diantara para pejabat organisasi, suatu cara untuk membuat rencana tertulis. Perencanaan strategis dapat juga diartikan sebagai suatu metode dalam mengarahkan para pemimpin unit kerja sehinggakeputusan-keputusan dan tindakanmereka mempunyai dampak terhadap masa depan organisasi dengan cara yang konsisten dan rasional. ${ }^{18}$

\footnotetext{
${ }^{17}$ J. Salusu, Pengambilan Keputusan Strategik Untuk Organisasi Publik dan Organisasi Non Profit (Jakarta: Grasindo, 2006), hlm. 500.

${ }^{18}$ J. Salusu, Pengambilan Keputusan Strategik Untuk Organisasi Publik dan Organisasi Non Profit (Jakarta: Grasindo, 2006), hlm. 500
} 
Lebih jauh Taylor dalam Salusu mengatakan bahwa perencanaan strategis dipandang sebagai metode untuk mengelola perubahan yang tidak dapat dihindari sehingga dapat juga disebut sebai metode untuk berurusan dengan kompleksitas lingkungan yang seringkali erat hubungannya dengan kepentingan organisasi. Tetapi, ia juga suatu metode untuk mengambil kompleksitas lingkungan internal yang ditimbulkan oleh bermacam-macam kebutuhan oleh setiap unit kerja dalam organisasi. Sedemikian besar peranan dari perencanaan strategis itu sehingga ia tidak dapat didelegasikan. Apabila terjadi pendegelasian dari eselon atas kepada eselon bawah dan sekaligus menghilangkan partisipasi aktif mereka, maka tekanannya berubah dari planning process menjadi plans book.

Steiner dalam Salusu menjelaskan perencanaan strategis adalah suatu kerangka berpikir logis yang menetapkan dimana anda berada, kemana anda akan pergi, dan bagaimana anda bisa ada disana. Ia juga merupakan proses yang mengarahkan para pemimpin mengembangkan visi dalam menggambarkan masa depan yang dikehendaki. Ia mengubah cara manajemen berpikir, mengalokasikan, dan merealokasikan berbagai sumber daya, sementara pelaksanaan program berlangsung. Dengan kata lain, perencanaan berhubungan dengan dampak masa depan dari keputusan yang dibuat sekarang, atau disebut sebagai futurity of current decisions. Ia mencakup pilihan-pilihan yang berkaitan dengan tujuan organisasi secara keseluruhan. Ia juga merangkul kekuatan-kekuatan 
eksternal yang tidak dapat dikendalikan. Bahkan perencanaan strategis adalah falsafah, yaitusuatu sikapa way of life, suatu proses berpikir, suatu aktivitas intelektual.

Dari pengertian strategi, dan perencanaan strategis diatas, menunjukan bahwa terdapat banyak versi dalam mendefinisikannya, namun tidak dapat perbedaan yang signifikan antara perencanaan strategis dan manajemen strategis, walaupun ada yang membedakannya. Oleh karena itu, penulis lebih cenderung pada arti perencanaan strategis yang sama dengan manajemen strategis yaitu metode untuk mengelola organisasi menghadapi perubahan lingkungan yang cepat dan kompleks dengan memformulasikan dan mengimplementasikan keputusan strategis untuk meraih tujuan dan masa depan organisasi. Hal ini seperti dijelaskan David bahwa istilah perencanaan strategis lebih umum digunakan dalam dunia bisnis, sementara manajemen strategis sering digunakan dalam bidang akademik. ${ }^{19}$ Walaupun demikian istilah perencanaan strategis di Indonesia akhir-akhir ini banyak dipakai dalam lembaga pendidikan baik di sekolah maupun perguruan tinggi.

Hal ini ditegaskan pula oleh Salusu bahwa apabila kita mencoba masuk ke berbagai literatur tentang manajemen strategis, kita akan menjumpai analisis yang sering ditemukan dalam pengambilan keputusan strategis dan perencanaan strategis. Demikian halnya, apabila kita menulusuri kepustakaan keputusan strategis maka kita akan menjumpai

${ }^{19}$ Fred R, David, Manajemen Strategis, Edisi Sepuluh (Jakarta: Salemba Empat, 2006),hlm. 6. 
ulasan-ulasan yang merupakan inti dari manajemen strategis dan perencanaan strategis. Dan, apabila kita bergumul dengan bahan pustaka mengenai perencanaan strategis, pada akhirnya yang kita temui adalah dimensi-dimensi yang banyak dibahas dalam manajemen strategis. ${ }^{20}$

Ilustrasi tersebut bagi Salusu memberikan keyakinan bahwa ketiganya merupakan kesatuanyang utuh, memiliki keterpautan pada derajat yang sangat tinggi, dan ketiganya memainkan peranan yang sangat vital dalam mengendalikan organisasi manapun, termasuk juga dalam organisasi pendidikan dalam hal ini sekolah.

\section{Karakteristik Perencanaan Strategis}

Dalam perkembangan wawasan manajemen, perencanaan strategis seringdiartikan sebagai perencanaan jangka panjang, yang meliputi ramalan-ramalan internal organisasi beserta kebijakan-kebijakan jangka panjang yang menjadi pedoman untuk mencapai tujuan. Istilah yang sering digunakan untuk menggantikan istilah "perencanaan strategis" juga berupa "perencanaan komprehensif".

Menurut John M. Bryson ${ }^{21}$, pada dasarnya istilah-istilah tersebut di atasmemiliki karakteristik yang berbeda. Perencanaan jangka panjang berbeda dengan perencanaan strategis, setidaknya hal itu dapat dilihat pada:Pertama, fokus perencanaan strategis berada pada pengidentifikasian dan pemecahan isu-isu, sedangkan perencanaan

20J. Salusu, Pengambilan Keputusan Strategik Untuk Organisasi Publik dan Organisasi Non Profit (Jakarta: Grasindo, 2006), hlm. 517

${ }^{21}$ John M. Bryson, Perencanaan Strategis bagi Organisasi Sosial (Yogyakarta: Pustaka Pelajar, 2001), hlm. 7. 
jangka panjang lebih fokus pada pengkhususan sasaran (goals) dan tujuan (objectives) serta menerjemahkannya ke dalam anggaran dan program kerja.

Kedua, perencanaan strategis lebih menekankan penilaian terhadap lingkungan di luar dan di dalam organisasi daripada yang dilakukan perencanaan jangka panjang. Perencanaan jangka panjang cenderung menganggap bahwa kecendrungan masa kini akan berlanjut hingga masa depan, sedangkan perencanaan strategis memperkirakan kecendrungan baru, diskontinuitas, dan berbagai kejutan. Oleh karena itu perencanaan strategis lebih mungkin mewujudkan perubahan yang bersifat kualitatif dan memasukkkan kemungkinan tentang rencana yang lebih luas.

Ketiga, perencanaan strategis dapat lebih mampu merumuskan versi idealisme organisasi dan mengusahakan bagaimana hal itu dapat tercapai karena perencanaan strategis bersifat kualitatif, sedangkan perencanaan jangka panjang biasanya merupakan garis ekplorasi garis lurus mengenai keadaan sekarang yang kerapkali diwujudkan dalam pernyataan tujuan yang mewakili projeksi mengenai kecendrungan yang terjadi.

Keempat, perencanaan stratategi lebih banyak berorientasi tindakan (action oriented) ketimbang perencanaan jangka panjang. Perencanaan strategis biasanya mempertimbangkan suatu rentang masa depan yang mungkin dan memfokuskan pada implikasi keputusan dan 
tindakan masa sekarang sehubungan denganrentang tersebut. Konsekuensi logisnya perencanaan strategis dapat mampumempertimbangkan berbagai keputusan dan tindakan serta menangkap sebanyakmungkin peluang yang terbuka bagi organisasi agar organisasi dapat menanggapikemungkinan yang tak terduga dengan tepat dan efektif. Sementara perencanaanjangka panjang cenderung mengasumsikan masa depan yang paling mungkin,dan kemudian mundur guna merencanakan urutan keputusan dan tindakan yangdiperlukan untuk menjangkau masa depan yang diasumsikan. Oleh karenanyaperencanaan jangka panjang terpaku pada arus tunggal dalam keputusan dantindakan yang tak mungkin dapat diharapkan jika masa depan tidak terjadi sepertiyang mereka asumsikan akan terjadi.

\section{Manfaat Perencanaan Strategis}

Stoner menjelaskan bahwa perencanaan strategis mampu memberikan pedoman yang sesuai untuk kegiatan organisasi karena dengan mengunakan perencanaan strategis, manajer dapat menjabarkan tujuan organisasinya yang ditentukan secara jelas lengkap dengan metode untuk mencapainya. ${ }^{22}$ Lebih jauh manfaat penting ainnya dari perencanaan strategis adalah bahwa ia membantu personalia organisasi mengenali peluang positif maupun negatif, tantangantantanganorganisasi, dan informasi yang luas karena perencanaan strategis itu sendiri mencakup bidang yang cukup luas, sehingga manajer 
organisasi dapat mampu memutuskan apa yang terbaik bagi organisasinya.

Beberapa penulis berkeyakinan bahwa perencanaan startegisdapat membantu suatu organisasi dalam beberapa point berikut: ${ }^{23}$

a. Berpikir secara strategis dan mengembangkan strategi-strategi yang efektif

b. Memperjelas arah masa depan

c. Menciptakan prioritas

d. Membuat keputusan sekarang dengan mengingat konsekuensi masa depan

e. Mengembangkan landasan yang kokoh bagi pembuatan keputusdan

f. Menggunakan keleluasaan yang maksimum dalam bidang-bidang yang berada di bawah control organisasi

g. Membuat keputusan yang melintasi tingkat dan fungsi

h. Memecahkan masalah utama organisasi

i. Menangani keadaanyang berubah dengan cepat secara efektif

j. Membangun kerja kelompok dan keahlian

\section{Proses Penyusunan Perencanaan Strategis}

Langkah-langkah dalam proses menyusun perencanaan strategis tidak ada standar baku, dan prosesnya mempunyai variasi yang tidak terbatas. Tiap penerapan perlu merancang variasinya sendiri sesuai kebutuhan, situasi dan kondisi setempat. Meskipun demikian, secara

${ }^{23}$ John M. Bryson, Perencanaan Strategis bagi Organisasi Sosial (Yogyakarta: Pustaka Pelajar, 2001), hlm. 12 
umum proses perencanaan strategis memuat unsur-unsur: (1) perumusan visi dan misi, (2) pengkajian lingkungan eksternal, (3) pengkajian lingkungan internal, (4) perumusan isu-isu strategis, dan (5) penyusunan strategis pengembangan (yang dapat ditambah dengan tujuan dan sasaran). Proses perencanaan strategis tidak bersifat sekuensial penuh, tapi dapat dimulai dari salah satu dari langkah ke (1), (2), dan (3). Ketiga langkah tersebut sangat saling mengisi. Setelah ketiga langkah pertama ini selesai, barulah dilakukan langkah ke (4), yang disusul dengan langkah ke (5). Setelah rencana strategis selesai disusun, maka diimplementasikan dengan terlebih dahulu menyusun rencana-rencana kerja (aksi/tindakan). ${ }^{24}$

Namun demikian, sebagaimana dikatakan oleh Umar, bahwa untuk membahas suatu perencanaan strategis hendaknya kita mengacu pada model manajemen strategis agar pembahasannya terfokus. Ia mengibaratkan ketika kita akan mendiskusikan rumah, paling tidak kita sudah tahu gambaran tentang rumah berfungsi untuk tempat tinggal, yang terdiri paling tidak atas ruang tamu, kamar tidur, dapur, kamar mandi. Kemudian ia mengambil tiga contoh model perencanaan strategis yang diambil dari pendapat pakar manajemen strategis yaitu: pertama, modeldari Wheelen Hunger; kedua, model dari Fred R. David; ketiga, model dari Glenn Baseman dan Arvind Piatak. Dari ketiga model tersebut, Umar menyebutkan beberapa elemen utama dalam perencanaan

${ }^{24}$ Achmad Junaedi, "Keragaman Pilihan Corak Perencanaan (Planning Styles) untuk Mendukung Kebijakan Otonomi Daerah”, dalam Seminar \& Temu Alumni MPKD 2000, Agustus 2000. 
strategis, yaitu: pertama, visi, misi dan falsafah (kredo/nilai-nilai); kedua,analisis lingkungan eksternal dan internal; ketiga, analisis pilihan strategis; keempat, sasaran jangka panjang; kelima, strategi fungsional; keenam,program, pelaksanaan, pengendalian, dan evaluasi. ${ }^{25}$

Dalam penelitian ini, Peneliti hanya mengambil dua model dari ketiga model yang dicontohkan Umar tersebut yaitu model yang ditawarkan Fred R. David, Wheelen-Hunger, dan ditambah dua model lain yang berbeda, yaitu modelnya perencanaan strategis oleh PearceRobinson dan Rohiat.

\section{a. Konsep Perencanaan Strategis Model Fred R. David}

Berikut ini adalah model komprehensif proses manajemen strategis yang diterima secara luas, walaupun dikatakan oleh David bahwa model ini tidak menjamin keberhasilan, tetapi model tersebut menunjukkan pendekatan dengan jelas dan praktis untuk memformulasi, mengimplementasi, dan mengevaluasi strategi.

David menyebutkan proses manajemen strategis, terdiri atas tiga langkah: formulasi strategi, implementasi strategi, dan evaluasi strategi. Dijelaskannya bahwa formulasi strategi termasuk mengembangkan visi dan misi, mengidentifikasi peluang dan ancaman eksternal perusahaan, menentukan kelemahan dan kekuatan

\footnotetext{
${ }^{25}$ Husein Umar, Strategic Managemen in Action, Konsep, Teori, dan Teknik Menganalisis Manajemen Strategis Strategic Business Unit Berdasarkan Konsep Michael R. Porter, Fred R. David, dan Wheelen Hunger, (jakarta: Gramedia Pustaka Utama, 2001), hlm. 19-27
} 
internal, menetapkan tujuan jangka panjang, merumuskan alternative strategi, dan memilih strategi tertentu yang akan dilaksanakan. ${ }^{26}$

Dalam implementasi strategi diisyaratkan perusahaan untuk menetapkan tujuan tahunan, membuat kebijakan, memotivasi karyawan, dan mengalokasikan sumber daya sehingga strategi yang telah diformulasikan dapat dijalankan.Implementasi strategi termasuk mengembangkan budaya yang mendukung strategi, menciptakan struktur organisasi yang efektif dan mengarahkan usaha pemasaran, menyiapkan anggaran, mengembangkan dan memberdayakan sistem informasi, dan menghubungkan kinerja karyawan dengan kinerja organisasi.

b. Konsep Perencanaan Strategis Model J.A. Pearce II dan Richard B Robinson, Jr

Kemudian Pearce dan Robinson juga menawarkan model manajemen strategi, meskipun terdapat pebedaan dalam rincian dan tingkat formulasi, komponen-komponen dasar dari model yang digunakan untuk menganalisis operasi manajemen strategis padaumumnya sangat serupa. Model yang ditawarkan ini menggambarkan urutan dan hubungan antara komponen utama dari proses manajemen strategis.

${ }^{26}$ Fred R. David, Manajemen Strategis, Edisi Sepuluh (Jakarta: Salemba Empat, 2006),hlm. 6-8 


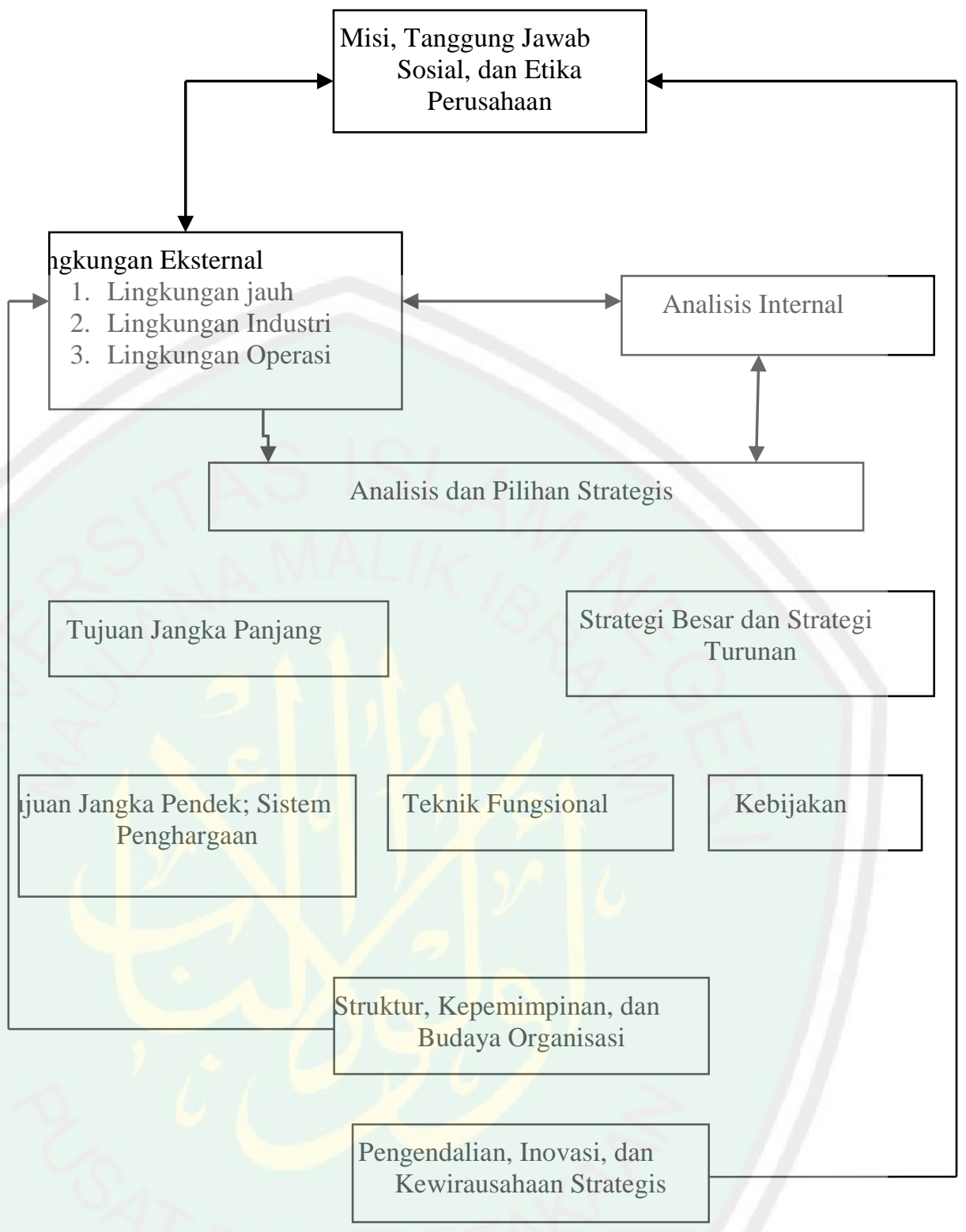

PearcedanRobinsonmenyebutkanbahwa

manajemenstrategisterdiri atas sembilan langkah atau tugas penting,yaitu: ${ }^{27}$

1) Merumuskan misi perusahaan, termasuk pernyataan luas mengenai maksud, filosofis, dan sasaran perusahaan

${ }^{27}$ John A. Pearce II dan Richard B. Robinson, Jr., Manajemen..., hlm. 4 
2) Melakukan suatu analisis yang mencerminkan kondisi dan kapabilitas internal perusahaan

3) Menilai lingkungan eksternal perusahaan, termasuk faktor persaingan dan faktor kontekstual umum lainnya

4) Menganalisis pilihan-pilihan yang dimiliki oleh perusahaanperusahaan dengan cara menyesuaikan sumber dayanya dengan lingkungan eksternal

5) Mengidentifikasi pilihan paling menguntungkan dengan cara mengevaluasi setiap pilihan berdasarkan misi perusahaan

6) Memilih satu set tujuan jangka panjang dan strategi utama yang akan menghasilkan pilihan paling menguntungkan tersebut

7) Mengembangkan tujuan tahunan dan strategi jangka pendek yang sesuai dengan tujuan jangka panjang dan strategi utama yang telah ditentukan

8) Mengimplementasikan strategi yang telah dipilih melalui alokasi sumber daya yang dianggarkan, dimana penyesuaian antara tugas kerja, manusia, struktur, teknologi, dan system penghargaan ditekankan.

9) Mengevaluasi keberhasilan proses strategi sebagai masukan pengambilan keputusan di masa dating.

Dari sembilan langkah atau tugas penting manajemen strategis tersebut, mengindikasikan bahwa manajemen strategis mencakup perencanaan, pengarahan, pengorganisasian, dan 
pengendalian atas keputusan dan tindakan terkait strategi perusahaan.

\section{c. Konsep Perencanaan Strategis Model J. David Hunger dan}

\section{Thomas L. Wheelen}

Manajemen strategis menurut Wheelen-Hunger adalah serangkaian keputusan dan tindakan manjerial yang menentukan kinerja organisasi dalam jangka panjang. ${ }^{28}$ Menurutnya dalam perencanaan strategis memiliki beberapa elemen dasar, yaitu seperti dijelaskan dalam gambar 2.3 berikut ini:

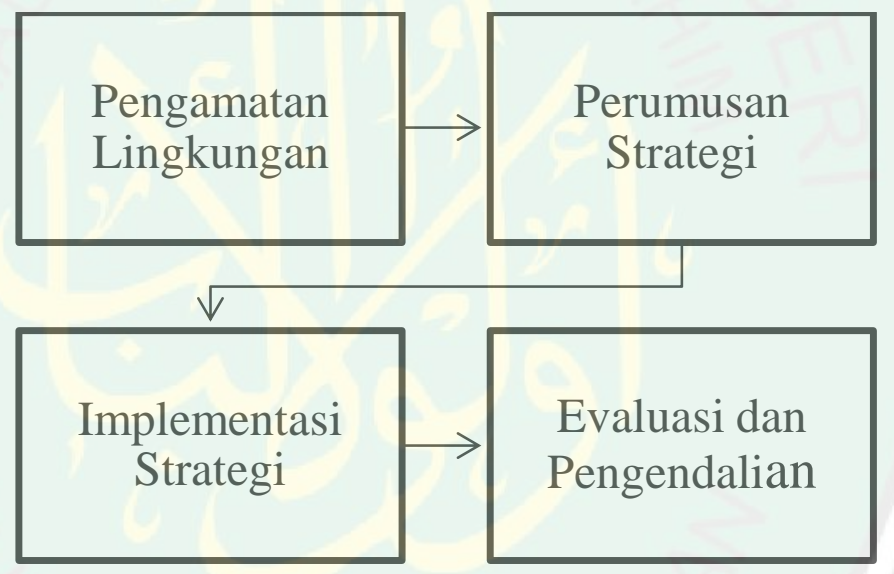

Gambar 2.3 Elemen-elemen Dasar dari Proses Manajemen Strategis ${ }^{29}$

1) Pengamatan lingkungan. Pengamatan lingkungan ini terdiri dari dua bagian yaitu, lingkungan eksternal dan lingkungan internal.

2) Perumusan strategi adalah pengembangan rencana jangka panjang untuk manajemen efektif dari kesempatan dan

${ }^{28}$ J. David Hunger \& Thomas L. Wheelen, Manajemen Strategis (Yogyakarta: Penerbit Andi, 2012), hlm. 4.

${ }^{29}$ J. David Hunger \& Thomas L. Wheelen, Manajemen Strategis (Yogyakarta: Penerbit Andi, 2012), hlm. 12. 
ancaman lingkungan, dilihat dari kekuatan dan kelemahan lembaga. Perumusan strategi meliputi menentukan misi perusahaan/organisasi, menentukan tujuan-tujuan yang dapat dicapai, mengembangkan strategi, dan menetapkan pedoman kebijakan.

3) Implementasi strategi

Proses mewujudkan strategi dan kebijakan dalam tindakan melalui pengembangan program, anggaran, dan prosedur.

a) Program adalah penyataan aktivitas-aktivitas atau langkah-langkah yang diperlukan untuk menyelesaikan perencanaan sekali pakai

b) Anggaran merupakan program yang dinyatakan dalam bentuk satuan uang, setiap program akan dinyatakan secara rinci dalam biaya, yang dapat digunakan oleh manajemen untuk merencanakan dan mengendalikan

c) Prosedur adalah suatu sistem langkah-langkah yang berurutan yang menggambarkan secara rinci bagaimana suatu tugas atau pekerjaan diselesaikan.

4) Evaluasi dan pengendalian. 
Proses yang melalui aktivitas-aktivitas organisasi dan hasil kinerja yang dimonitor dan kinerja sesungguhnya dibandingkan dengan kinerja yang diinginkan. ${ }^{30}$

\section{d. Konsep Perencanaan Strategis Model Rohiat}

Dalam lembaga pendidikan seperti sekolah, rencana strategis biasanya disebut atau dituangkan dalam dokumen "Rencana Pengembangan Sekolah" (RPS). Rencana pengembangan sekolah (RPS) adalah sebuah dokumen perencanaan yang dibuat oleh sekolah untuk mengadakan perubahan fisik dan nonfisik sekolah dalam rangka meningkatkan mutu pelayanan sekolah. RPS menggambarkan peta perjalanan perubahan sekolah dari satu kondisi menuju yang lebih baik dan lebih menjanjikan dalam kurun lima tahun kedepan. ${ }^{31}$

Adapun langkah dalam menyusun rencana strategis menurut Rohiyat sebagai berikut:

1) Melakukan analisis lingkungan strategis sekolah

2) Melakukan analisis situasi pendidikan sekolah saat ini

3) Melakukan analisis situasi pendidikan sekolah yang diharapkan pada lima tahun kedepan

4) Menentukan kesenjangan antara situasi pendidikan sekolah saat ini dan yang diharapkan lima tahun kedepan

${ }^{30}$ J. David Hunger \& Thomas L. Wheelen, Manajemen Strategis (Yogyakarta: Penerbit Andi, 2012), hlm. 11-19. 
5) Merumuskan visi sekolah

6) Merumuskan misi sekolah

7) Menentukan strategi pelaksanaan pada sekolah

8) Menentukan tonggak-tonggak kunci keberhasilan

9) Menentukan rencana biaya

10) Membuat rencana pemantauan dan evaluasi

\section{Pendekatan dalam Perencanaan Strategis}

Perencanaan strategis pada dasarnya memiliki sejarah yang cukup panjang. Selama perjalanan waktu yang cukup panjang tersebut, telah dihasilkan banyak pendekatan perencanaan strategis yang diterapkan oleh organisasi profit maupun non profit di berbagai belahan dunia dan menunjukkan bahwa pendekatan perencanaan strategis yang dikembangkan dapat membantu mengatasi lingkungan yang sedang berubah secara dramatis, dan dengan demikian dapat membantu organisasi tersebut menjadi lebih efektif.

Secara mendasar terdapat empat pendekatan dasar terhadap perencanaan strategis, yaitu: ${ }^{32}$

a. Pendekatan dari bawah ke atas (bottom-up approach)

Perumusan strategis dalam pendekatan ini diambil dari berbagai unitatau divisi organisasi lalu kemudian disampaikan ke atas untuk disatukanpada tingkat organisasi. Dalam hal ini personalia organisasi diberikepercayaan penuh untuk menyumbangkan

\footnotetext{
${ }^{32}$ Husein Umar, Strategic Management in Action (Jakarta: Gramedia Pustaka Utama, 2001), hlm.
} 14. 
aspirasinya mengenai strategiorganisasi dalam rangka pencapaian tujuan organisasi secara lebihefektif dan efisien.

Pendekatan semacam ini meniscayakan adanya kelemahan bahwa strategi organisasi dapat terwujud menjadi perencanaan yang tidak koheren, tidak terpadu dan tidak bersinergi.

b. Pendekatan dari atas ke bawah (top-down approach)

Perencanaan strategis dirumuskan oleh pimpinan puncak organisasisecara terpadu dan terkoordinasi, yang biasanya juga dibantu olehmasukan-masukan dari para manajer dibawahnya. Strategi yangmenyeluruh ini lalu digunakan untuk menetapkan sasaran danmengevaluasi kinerja dari setiap unit usaha;

c. Pendekatan interaktif

Perencanaan dalam pendekatan ini menekankan pada pentingnya peran komunikasi secara interaktif dalam perumusan perencanaan strategis antara pimpinan puncak dan manajer-manajer dibawahnya. Pengembangan strategi pada tingkat yang lebih lanjut kemudian dikonsultasikan bersama dengan membuat mata rantai antara sasaran organisasi yang lebih luas dan pengetahuan terinci para manajer mengenai situasi khusus.

d. Pendekatan dua tingkat

Dalam pendekatan ini strategi dirumuskan secara independen padatingkat organisasi dan tingkat unit usaha. Semua unit membuat rencanaagar sesuai dengan situasi khusus mereka, dan rencana ini 
secara teraturdinilai oleh manajemen organisasi. Pada tingkat organisasi, perencanaanstrategi dilanjutkan dan difokuskan pada tujuan-tujuan yang lebih besardari organisasi: kapan memperoleh dan kapan menarik diri dari suatukegiatan usaha; bagaimana bereaksi terhadap kompetisi dan lingkunganeksternal; prioritas apa yang harus dilekatkan pada masing-masing unitusaha.

\section{Perencanaan Strategis di Sekolah}

Setelah mengetahui langkah-langkah dalam perencanaan strategis, perlu diketahui juga bahwa dalam perencanaan srategis terdapat istilah renstra atau rencana strategis. Sekolah atau madrasah diwajibkan membuat: ${ }^{33}$

a. Rencana kerja jangka menengah yang menggambarkan tujuan yang akan dicapai dalam kurun waktu empat tahun yang berkaitan dengan mutu lulusan yang ingin dicapai

b. Rencana kerja tahunan yang dinyatakan dalam rencana kegiatan dan anggaran sekolah yang dilaksanakan berdasarkan rencana jangka menengah.

Renstra sekolah berisi tentang cara pencapaian tujuan sekolah yang dilakukan melalui berbagai perencanaan dan program sekolah yang dituangkan dalam rencana kerja sekolah (RKS). ${ }^{34}$

\footnotetext{
${ }^{33}$ Permendiknas 19 Tahun 2007 Tentang Standar Pengelolaan Pendidikan oleh Satuan Pendidikan Dasar dan Menengah

${ }^{34}$ Muhaimin, Sutiah dan Sugeng Listyo, Manajemen Pendidikan (Jakarta: Prenadamedia Group, 2012), hlm. 199.
} 
Rencana kerja sekolah (RKS) merupakan rencana yang komprehensif untuk mengoptimalkan pemanfaatan segala sumber daya yang ada dan yang mungkin diperoleh guna mencapai tujuan yang diinginkan di masa datang. RKS harus berorientasi ke depan dan secara jelas bagaimana menjembatani antara kondisi saat ini dan harapan yang ingin dicapai di masa depan. ${ }^{35}$

Pelaksanaan program sekolah yang sudah ditetapkan namun tidak sesuai dengan rencana perlu mendapat persetujuan melalui rapat dewan pendidik dan komite sekolah. Kepala sekolah mempertanggung jawabkan pelaksanaan pengelolaan bidang akademik pada rapat dewan pendidik dan bidang non akademik dengan komite sekolah dalam bentuk laporan pada akhir tahun ajaran yang disampaikan sebelum penyusunan rencana kerja tahunan berikutnya.

Perancanaan dilakukan bukan hanya untuk mengatasi masalah yang sedang dihadapi,tetapi juga untuk meningkatkan mutu sekolah. Rencana kerja sekolah yang telah dikembangkan oleh tim sekolah seharusnya dapat dibaca oleh semua stakeholderssekolah. Hal tersebut dilakukan untuk mengantisipasi adanya perubahan dan usaha yang mungkin dapat memperkaya program yang telah disusun.

${ }^{35}$ Muhaimin, Sutiah dan Sugeng Listyo, Manajemen Pendidikan (Jakarta: Prenadamedia Group, 2012), hlm. 200-201. 


\section{B. Peningkatan Mutu Pendidikan}

\section{Pengertian Mutu Pendidikan}

Secara umum, mutu adalah derajat (tingkat) keunggulan suatu produk (hasil kerja/upaya) bak berupa barang maupun jasa, baik tangible maupun intangible. ${ }^{36}$

Gaspersz menjelaskan bahwa mutu memiliki banyak definisi yang berbeda dan bervariasi dari konvensional sampai modern. Definisi konvensional mendefinisikan mutu adalah karakteristik langsung dari suatu produk, sedangkan secara modern mutu adalah segala sesuatu yang mampu memenuhi keinginan atau kebutuhan pelanggan. ${ }^{37}$

Menurut Arcaci dalam buku Nur Zazin menjelaskan bahwa mutu adalah sebuah derajat variasi yang sesuai dengan standar yang rendah. Menurut Daming dalam Nur Zazin, mutuberarti pemecah untuk mencapai penyempurnaan terus menurus. Dalam dunia pendidikan, menurut Daming, yang dapat diterapkan adalah (1) anggota dewan sekolah dan administrasi harus menetapkan tujuan pendidikan, (2) menekankan pada upaya kegagalan pada siswa, (3) menggunakan metode kontrol statistik untuk membantu memperbaiki outcome siswa dan administrasi. Menurut Syaiful Sagala, mutu merupakan penilaian suatu produk yang memenuhi kriteria, standar atau rujukan tertentu. ${ }^{38}$

\footnotetext{
${ }^{36}$ Nur Zazin, Gerakan Menata Mutu: Teori \& Aplikasinya, (Jogjakarta: Ar-Ruzz media, 2011), hlm. 54.

${ }^{37}$ Gasperz, Jurnal "Penerapan Total Management in Education (TQME) pada Pergruan Tinggi di Indonesia", jilid 6 (2002), hlm. 16.

${ }^{38}$ Nur Zazin, Gerakan Menata Mutu: Teori \& Aplikasinya, (Jogjakarta: Ar-Ruzz media, 2011), hlm. 54
} 
Sedangkan menurut Croby dalam bukunya Rusman berpendapat bahwa mutu adalah kesesuaian dengan kebutuhan yang meliputi availability, delivery, realibility, maintainbility,dan cost effectiveness. ${ }^{39}$ Mutu memiliki pengertian yang beragam dan memiliki implikasi yang berbeda jika diterapkan pada sesuatu, semua tergantungpada barang apa yang dihasilkan, dipakai, dan anggapan seseorang. Berdasarkan pengertian mutu diatas penulis menyimpulkan bahwa mutu adalah tingkat pencapaian sesuatu sesuai dengan standar dan kriteria yang telah ditentukan, baik tangible maupun intangible.

Mutu dalam dunia pendidikan dapat dirumuskan melalui hasil belajar mata pelajaran skolastik yang dapat diukur secara kuantitatif, dan pengamatan yang bersifat kualitatif, khususnya untuk bidang-bidang pendidikan sosial. Rumusan mutu pendidikan bersifat dinamis dan dapat ditelaah dari berbagai sudut pandang. Kesepakatan tentang konsep mutu dikembalikan pada rumusan acuan atau rujukan yang ada seperti kebijakan pendidikan, proses belajar mengajar, kurikulum, sarana prasarana, fasilitas pembelajaran dan tenaga kependidikan sesuai dengan kesepakatan pihak-pihak yang berkepentingan.

Peningkatan mutu pendidikan diperoleh melalui dua strategi, yaitu peningkatan mutu pendidikan yang berorientasi akademis untukmemberidasar minimal dalam perjalanan yang harus ditempuh mencapai mutu pendidikan yang dipersyaratkan oleh tuntutan zaman, dan

${ }^{39}$ Rusman, Manejemen Kurikulum (Jakarta:PT Raja Grafindo Persada, 2009), hlm. 154 
peningkatan mutu pendidikan yang berorientasi pada keterampilan hidup yang essesial yang dicakupi oleh pendidikan yang berlandaskan luas, nyata dan bermakna. ${ }^{40}$

Sekolah dikatakan bermutu apabila prestasi sekolah khusunya prestasi peserta didik menunjukkan pencapaian yang tinggi dalam: ${ }^{41}$

a. Prestasi akademik yaitu nilai rapor dan nilai kelulusan memenuhi standar yang ditentukan.

b. Memiliki nilai-nilai kejujuran, ketaqwaan, kesopanan, dan mampu mengapresiasi nilai-nilai budaya.

c. Memiliki tanggung jawab yang tinggi dan kemampuan yang diwujudkan dalam bentuk keterampilan sesuai dengan dasar ilmu yang diterimanya di sekolah.

Jadi dapat disimpulkan bahwa mutu pendidikan adalah tingkat pencapaian pendidikan yang sesuai dengan kriteria dan standar pendidikan baik secara internal maupun eksternal yang menunjukkan kemampuan memuaskan kebutuhan yang diharapkan dan berkaitan dengan input, process, dan outputpendidikan.

\section{Kriteria Pencapain Mutu Pendidikan}

Menurut Tobroni adaempat kategori sekolah dilihat dari mutu dan proses pendidikannya, yaitu bad school (sekolah yang buruk), good school (sekolah yang baik), effective school (sekolah yang efektif), dan excellence school (sekolah yang unggul). Bad school adalah sekolah yang memiliki input yang baik atau sangat baik tetapi proses pendidikannya tidak baik dan menghasilkan outputyang tidak bermutu.

\footnotetext{
${ }^{40}$ Syaiful Sgala, Manajemen StrategikDalam Peningkatan Mutu Pendidikan (Bandung: Alfabeta,2009), hlm. 170

${ }^{41}$ Syaiful Sgala, Manajemen Strategik Dalam Peningkatan Mutu Pendidikan (Bandung: Alfabeta,2009), hlm. 170-171
} 
Good school adalah sekolah yang memiliki input yang baik, proses yang baik, dan hasilnya (output-nya) baik. Effective school adalah sekolah yang memiliki input baik/kurang baik, proses pendidikannya sangat baik dan menghasilkan output baik/sangat baik. Sedangkan excellence school adalah sekolah yang inputnya sangat baik, prosesnya sangat baik dan menghasilkan lulusan (output) yang sangat baik. ${ }^{42}$

Menurut Departemen Pendidikan dan Kebudayaan, sekolah mempunyai pendidikan yang bermutu jika mempunyai kriteria sebagai berikut: ${ }^{43}$

a. Input terseleksi secara ketat dengan kriteria tertentu dan melali prosedur yang dapat dipertanggung jawabkan. Kriteria yang dimaksudkan adalah; (1) prestasi belajar superior dengan indikator angka raport, nilai hasil tes prestasi akademik; (2) skor psikotes yang meliputi intelegensi dan kreativitas; (3) tes fisik, jika diperlukan.

b. Sarana dan prasarana yang menunjang untuk memenuhi kebutuhan belajar siswa serta menyalurkan minat dan bakatnya, baik dalam kegiatan kurikuler maupun ekstrakurikuler.

c. Lingkungan belajar yang kondusif untuk berkembangnya potensi keunggulan menjadi keunggulan yang nyata baik lingkungan fisik maupun sosial psikologis.

d. Guru dan tenaga kependidikan yang menangani harus unggul baik dari segi penguasaan materi pelajaran, metode mengajar, maupun

\footnotetext{
${ }^{42}$ http://subagio-subagio.blogspot.co.id/2011/01/mengukur-mutu-sekolah-1.html, diakses pada tanggal 5 september 2017 pukul 21.45

${ }^{43}$ Depdikbud, Pengembangan Sekolah Unggul, Jakarta, Dirjen Disdasmen, 1994.
} 
komitmen dalam melaksanakan tugas. Untuk itu perlu disediakan intensif tambahan bagi guru berupa uang maupun fasilitas lainnya seperti perumahan dan transportasi.

e. Kurikulumnya diperkaya dengan pengembangan dan improvisasi secara maksimal sesuai dengan tuntutan belajar peserta didik yang memiliki kecepatan belajar serta motivasi belajar yang lebih tinggi dibanding dengan siswa seusianya.

f. Kurun waktu belajar lebih lama dibanding sekolah lain. Karena itu perlu ada asrama untuk memaksimalkan pembinaan dan menampung siswa dalam berbagai lokasi. Di kompleks asrama perlu ada sarana yang bisa menyalurkan minat dan bakat siswa seperti perpustakaan, alat-alat olahraga, kesenian dan lain-lain yang diperlukan.

g. Proses belajar harus berkualitas dan hasilnya dapat dipertanggung jawabkan, baik kepada siswa, lembaga ataupun masyarakat.

h. Sekolah unggul tidak hanya memberikan manfaat kepada peserta didik di sekolah tersebut, tetapi harus memiliki resonansi sosial terhadap lingkungan sekitar.

i. Nilai lebih sekolah unggul terletak pada perlakuan tambahan di luar kurikulum nasional melalui pengembangan kurikulum, program pengayaan dan peluasan, pengajaran remidial. Pelayanan, bimbingan dan konseling yang berkualitas, pembinaan kreativitas dan disiplin.

Mewujudkan sekolah yang mempunyai pendidikan bermutu diawali dengan mengadopsi dedikasi bersama terhadap mutu oleh dewan 
madrasah, administrator, staff, siswa, guru dan komunitas. Proses diawali dengan mengembangkan visi dan misi mutu untuk wilayah dan setiap sekolah serta departemen dalam wilayah tersebut. visi mutu difokuskan pada lima hal yaitu: ${ }^{44}$

a. Pemenuhan kebutuhan konsumen

Dalam sebuah sekolah yang bermutu, setiap orang menjadi kostumer dan sebagai pemasok sekaligus. Secara khusus kustomer sekolah adalah siswa dan keluarganya, merekalah yang akan memetik manfaat dari hasil proses sebuah lembaga pendidikan. Sedangkan dalam kajian umum kustomer sekolah itu ada dua yaitu internal meliputi orang tua, siswa, guru, administrator, staff, dan dewan sekolah yang berada dalam system pendidikan. Dan kustomer eksternal yaitu, masyarakat, perusahaan, keluarga, militer, dan perguruan tinggi yang berada diluar organisasi namun memanfaatkan outputdari proses pendidikan.

b. Keterlibatan total komunitas dalam program

Setiap orang juga harus terlibat dan berpartisipasi dalam rangka menuju kearah transformasi mutu. Mutu bukan hanya tanggung jwab dewan sekolah atau pengawas, akan tetapi merupakan tanggung jawab semua pihak.

${ }^{44}$ Gunawan Imam, http://duniainformatikaindonesia.blogspot.com/2013/03/ciri-ciri-mutupendidikan.html. 
c. Pengukuran nilai tambahan pendidikan

Pengukuran ini justru yang seringkali gagal dilakukan di sekolah. Secara tradisional ukuran mutu atas sekolah adalah prestasi siswa, dan ukuran dasarnya adalah ujian. Bilamana hasil ujian bertambah baik, maka mutu pendidikan pun membaik.

d. Memandang pendidikan sebagai suatu sistem Pendidikan mesti dipangan sebagai suatu sistem, ini merupakan konsep yang amat sulit dipahami oleh para professional pendidikan. Hanya dengan memandang pendidikan dapat mengeliminasi pemborosan dari pendidikan dan dapat memperbaiki mutu setiap proses pendidikan.

e. Perbaikan berkelanjutan dengan selalu berupaya keras membuat output pendidikan menjadi lebih baik.

\section{Sasaran Mutu Pendidikan}

Menurut Mohammad Syaifuddin, sasaran pendidikan adalah tujuan yang dirumuskan dengan memperhitungkan tantangan yang dihadapi sekolah. Sasaran dapat disebut juga tujuan jangka pendek (1 tahun). ${ }^{45}$

Menurut Depdiknas tahun 2002, sasaran ialah penjabaran tujuan.

Sasaran harus mengandung peningkatan baik mutu, produktivitas,

${ }^{45}$ Syaifuddin, Muhammad. Manajemen Berbasis Sekolah, (Jakarta: Dirjen Dikti Depdiknas, 2007), hlm.3. 
efektivitas, maupun efisiensi. Sasaran sebaiknya dibuat satu tahun ajaran. $^{46}$

Dari pengertian diatas dapat disimpulkan bahwa sasaran mutu pendidikan merupakan suatu yang akan dihasilkan/dicapai oleh lembaga dalam jangka waktu lebih singkat dibanding dengan tujuan sekolah. Agar sasaran dapat dicapai dengan efektif, maka sasaran harus dibuat spesifik, terukur, jelas kriterianya, dan disertai indikator-indikator yang rinci dan mengacu pada visi, misi dan tujuan sekolah. Adapun karakteristik sasaran mutu sebagai berikut:

a. Sasaran merupakan tujuan jangka pendek (1 tahun)

b. Sasaran mengandung peningkatan baik peningkatan kualitas, efektivitas, produktivitas, maupun efisiensi.

c. Prioritas harus dipertimbangkan sungguh-sungguh

d. Sasaran harus dibuat secara spesifik

e. Kriteria sasaran harus jelas dan disertai indikator-indikator yang rinci

f. Sasaran didasarkan pada tantangan, visi, mis, dan tujuan

Mengacu pada klausul 5.3 standar ISO 9001:2008 dan IWA 2:2007, terdapat hal berkenaan dengan sasaran mutu sebagai berikut: ${ }^{47}$

a. Sasaran mutu harus sesuai dengan maksud organisasi, dalam hal ini visi, misi, dan tujuan.

\footnotetext{
${ }^{46}$ Departemen Pendidikan Nasional. Manajemen Peningkatan Mutu Berbasis Sekolah (Jakarta: Direktorat Jenderal Pendidikan Dasar dan Menengah Direktorat Sekolah Lanjutan Tingkat Pertama, 2002)

${ }^{47}$ http://erfiilyas.blogspot.com/2013/11/kebijakan-mutu-persyaratan-dan.html., diakses pada tanggal 6 September 2017 pukul 22.00
} 
b. Sasaran mutu harus mencakup komitmen untuk memenuhi persyaratan. Baik persyaratan pelanggan maupun peraturan perundang-undangan. Untuk institusi pendidikan termasuk persyaratan akreditasi dan kebijakan organisasi pendidikan lainnya.

c. Sasaran mutu juga harus memuat komitmen untuk senantiasa memperbaiki efektifitas sistem manajemen mutu

d. Sasaran mutu juga harus menyediakan kerangka kerja untuk menetapkan dan meninjau tujuan

e. Sasaran mutu harus didokumentasikan, dikomunikasikan dan dipahami serta diimplementasikan oleh seluruh anggota organisasi

f. Sasaran mutu harus selalu ditinjau untuk memastikan kesesuainnya dengan kondisi organisasi.

Dari karakteristik sasaran mutu pendidikan diatas dapat disimpulkan bahwa dalam menyusun sasaran mutu pendidikan perlu melibatkan berbagai pihak yang berkepentingan (stakeholders) seperti guru, siswa, tata usaha/karyawan, orang tua siswa, komite sekolah dan tokoh masyarakat yang memiliki perhatian kepala sekolah, sehingga akan menjadi milik semua warga sekolah dengan kemampuan masing-masing artinya setiap orang dilibatkan sesuai dengan kemampuan dan kepentingan. Yang perlu dijagaadalah rasa terwakili dalam proses penyusunan dan rasa memiliki terhadap hasil. Seluruh warga sekolah harus merasa ikut menentukan dalam proses penyusunan sasaran mutu 
sehingga merasa ikut memiliki dan akhirnya wajib untuk melaksanakannya.

Rencana pengembangan sekolah merupakan rencana pengembangan sekolah yang disusun bersama oleh sekolah dan komite. Kebutuhan sekolah dan aspirasi masyarakat menjadi dasar utama penyusunan rencana pengembangan sekolah (RPS). Dengan kata lain, RPS bertujuan untuk mengemukakan apa yang diperlukan madrasah serta harapan sekolah serta harapan masyarakat terhadap sekolah. Dengan demikian rencana sekolah berdasarkan duajenis masukan, yaitu: 1) keterangan lengkap mengenai keadaan sekolah, 2) pandangan atau aspirasi masyarakat danpengguna jasa atau pandangan dan harapan dan harapan pihak-pihak yang berkepentingan (stakeholders) ${ }^{48}$

Mencermati pernyataan Muhaimin tersebut dapat dipahami bahwa dengan adanya rencana yang jelas, semua pihak yang berkepentingan (orang tua, guru, pegawai, komite, warga sekitar). Sekolah itu sendiri akan mengetahui apa yang akan dibutuhkan oleh sekolah, apa yang perlu dilakukan selama beberapa tahun yang akan datang. Dalam perencanaan harus jelas serial kegiatan seperti identifikasi, pembatasan, seleksi, dan prioritas kebutuhan atau analisis kebutuhan.

Perencanaan sekolah merupakan gambaran masa depan dari sosok institusi sekolah yang dikehendaki oleh warganya. Setiap sekolah

\footnotetext{
${ }^{48}$ Muhaimin, Manajemen Pendidikan: Aplikasi dan Penyusunan Rencana Pengembangan
} Madrasah (Jakarta: Prenada Media Group, 2009), hlm. 200. 
harus mempunyai rencana yang komprehensif untuk mengoptimalkan pemanfaatan sumber daya yang ada yang mungkin diperoleh guna mencapai tujuan yang ingin dicapai di masa yang akan datang. Dalam perencanaan strategis peningkatan mutu sekolah harus mengfokuskan dan memandu prestasi siswa dan etos pembelajaran dari staff pada tingkat unitnya. ${ }^{49}$

Lembaga pendidikan yang melaksanakan manajemen peningkatan mutu berbasis sekolah harus membuat rencana pengembangan sekolah. Rencana pengembangan sekolah pada umumnya mencakup rumusan visi, misi, tujuan sekolah dan strategi pelaksanaanya. Sedangkan rencana kerja sekolah pada umumnya meliputi pengidentifikasian sasaran yag telah diidentifikasi, dianalisisSWOT, langkah-langkah pemecahan persoalan dan penyusunan rencana dan program kerja madrasah. ${ }^{50}$

Indikasi permasalahan sekolah secara tidaklangsung akan memikirkan tantangan masa depan dengan merumuskan target-target atau sasaran kelembagaan yang operasional dan dijangkau pelaksanaannya oleh para pengelola dan pelaksana lembaga, dengan demikian visi merupakan gambaran masa depan yang diinginkan sekolah agar sekolah menjamin kelangsungan hidup dan perkembangannya. Misi adalah tindakan untuk mewujudkan/merealisasikan visi tersebut. tujuan merupakan "apa" yang akan dicapai/dihasilkan oleh lembaga dan

\footnotetext{
${ }^{49}$ Sudarwan Danim, Visi Baru Manajemen Sekolah (Jakarta: Bumi Aksara, 2006), hlm. 109. ${ }^{50}$ Depdiknas, Manajemen Peningkatan Mutu Berbasis Madrasah: Konsep Dasar (Jakarta: Ditjen Dikdanmen, 2002), hlm. 32.
} 
"kapan” tujuan akan dicapai jika visi, misi terkait dengan jangka waktu yang panjang, maka tujuan dikaitkan dengan jangka waktu 3-5 tahun. ${ }^{51}$

\section{Faktor-faktor Pendukung dan Penghambat Dalam Peningkatan}

\section{Mutu Pendidikan}

Keberhasilan program peningkatan mutu pendidikan tidak dapat terlepas dari dukungan faktor-faktor yang mempengaruhi. Faktor-faktor pendukung peningkatan mutu pendidikan sebagai berikut: ${ }^{52}$

a. Kurikulum dan Pembelajaran

Kurikulum dan pembelajaran ini memiliki peranan yang sangat penting dalam keberhasilan program peningkatan mutu pendidikan.

Hal ini tidak hanya dengan dokumen tertulis yang memuat sejumlah mata pelajaran yang diajarkan ke siswa, tetapi juga memuat rumusan tujuan-tujuan yang hendak dicapai dalam rangka mewujudkan visi dan misi sekolah. Selain itu kurikulum juga dirumuskan strategi/metode dan teknik-teknik pembelajaran, sumber-sumber, alat-alat, dan media yang dibutuhkan bahkan pendekatan penilain terhadap keberhasilan pembelajaran.

b. Administrasi atau Manajemen

Administrasi ini jugamerupakan faktor penting dalam peningkatan mutu pendidikan. Administrasi dilihat dari sasaran pelayanannya dapat dibedakan menjadi:

\footnotetext{
${ }^{51}$ Depdiknas, Manajemen Peningkatan Mutu Berbasis Madrasah: Konsep Dasar (Jakarta: Ditjen Dikdanmen, 2002), hlm. 33

${ }^{52}$ Minnah El Widdah, dkk, Kepemimpinan Berbasis Nilai dan Pengembangan Mutu Madrasah (Bandung: Alfabeta, 2012), hlm. 104-108
} 
- Pelayanan administrasi siswa

- Pelayanan administrasi personil

- Pelayanan administrasi sarana dan prasarana

- Pelayanan administrasi kurikulum

Kegiatan pelayanan ini pada dasarnya merupakan suatu sistem, dimana antara pelayanan satu dengan yang lain saling berhubungan dan saling mempengaruhi. Oleh sebab itu, pelayanan administrasi sangat mempengaruhi dalam peningkatan mutu pendidikan.

c. Organisasi kelembagaan

Organisasi kelembagaan merupakan faktor pendukung keberhasilan peningkatan mutu pendidikan. Faktor-faktor tersebut meliputi mulai dari kepemilikan akte pendirian/kelembagaan, memiliki hubungan sejenis, struktur organisasi yang lengkap, struktur organisasi sekolah disusun sesuai dengan beban kerja dan kebutuhan.

d. Sarana prasarana

Kelayakan fasilitas sekolah baik kualitas maupun kuantitas merupakan faktor yang mempengaruhi keberhasilan peningkatan mutu pendidikan. Fasilitas disini meliputi bangunan fisik sekolah, ruang kelas, perpustakaan, laboratorium d1l. Kelayakan fasilitas sekolah tidak dapat terlepas dari pertimbangan peningkatan mutu sekolah. 
e. Ketenagaan (guru dan staff TU)

Kemampuan guru dan personil sekolah juga sangat mempengaruhi dalam pencapaian peningkatan mutu pendidikan. Sebagai guru yang profesional harus mampu melakukan tugas-tugasnya terutama merencanakan, melaksanakan, dan menilai keberhasilanpembelajaran. Selainitu guru juga dituntut harus memiliki kompetensi personil dan sosial yang relevan dengan profesinya sebagai tenaga edukatif.

f. Pembiayaan

Operasional kegiatan peningkatan mutu pendidikan tidak lepas dari dukungan biaya, karena sekolah sebagai suatu organisasi kependidikan harus mencari dana tambahan untuk mengembangkan program-program dalam rangka peningkatan mutu pendidikan.

g. Siswa

Sebagai salah satu input pada sistem sekolah, maka keadaan siswa harus dipertimbangkan sedemikian rupa sehingga dapat diproses untuk meningkatkan kompetensinya, karena siswa juga merupakan faktor yang sangat berpengaruh dalam peningkatan mutu pendidikan.

h. Partisipasi Masyarakat

Keberhasilan program peningkatan mutu pendidikan tentu didukung dengan partisipasi dari masyarakat. Dengan kata lain, peran serta dan partisipasi dari masyarakat ini meliputi dari keterlibatan orang tua siswa dalam menyusun program, keterlibatan dalam pelaksanaan 
peningkatan mutu pendidikan, keterlibatan komite sekolah dalam meningkatkan efektivitas pembelajaran, pelaporan pelaksanaan program pada pihak orang tua dan komite sekolah.

i. Lingkungan budaya sekolah

Lingkungan dan budaya sekolah terhadap pencapaian tujuan bagi peningkatan mutu pendidikan, dalam hal ini ditandai dengan adanya program keamanan dengan prosedur dan jadwal tertentu, adanya program keindahan lingkungan, ketertiban, disiplin dalam berpakaian, penyelenggaraan kelompok belajar, penerapan budaya sekolah yang menjadi ciri khas sekolah yang bersangkutan.

Selain faktor pendukung yang sudah dijelaskan diatas, ada juga faktor yang cenderung menghambat keberhasilan program peningkatan mutu pendidikan, antara lain: (a) rendahnya dukungan masyarakat terhadap lembaga pendidikan sekolah, (b) lemahnya kepemimpinan sekolah, (c) rendahnya profesionalitas guru, (d) kurang optimalnya sarana dan prasarana sekolah, (e) kurang berdayanya komite sekolah.

\section{Standar Mutu Pendidikan}

Secara nasional standar mutu pendidikan merujuk pada Peraturan Pemerintah nomor 19 tahun 2005 yang menyatakan bahwa standar nasional pendidikan (SNP) meliputi: ${ }^{53}$ 
a. Standar Isi

Standar isi adalah ruang lingkup materi dan tingkat kompetensi yang dituangkan dalam kriteria tentang kompetensi tamatan, kompetensi bahan kajian, kompetensi mata pelajaran, dan silabus pembelajaran yang harus dipenuhi oleh peserta didik pada jenjang dan jenis pendidikan tertentu.

b. Standar Proses

Standar proses adalah standar nasional pendidikan yang berkaitan dengan pelaksanaan pembelajaran pada satu satuan pendidikan untuk mencapai standar kompetensi lulusan. Ruang lingkup standar proses untuk satuan pendidikan dasar dan menengah menurut Permendiknas RI nomor 41 tahun 2007 mencakup perencanaan proses pembelajaran, pelaksanaan proses pembelajaran, penilaian hasil belajar, dan pengawasan proses pembelajaran.

Dari segi proses, suatu pendidikan disebut bermutu apabila peserta didik mengalami proses pembelajaran yang riil dan bermakna, yang ditunjang oleh proses belajar mengajar yang efektif. Proses pembelajaran pada satuan pendidikan diselenggarakan secara interaktif, inspiratif, menyenangkan, menantang, memotivasi peserta didik untuk berpartisisfasi aktif, serta memberikan ruang yang cukup bagi prakarsa, kreativitas, dan kemandirian sesuai dengan bakat, minat dan perkembangan fisik serta psikologis peserta didik. Selain itu dalam proses pembelajaran pendidik memberikan keteladanan. 
c. Standar Kompetensi Lulusan

Standar kompetensi lulusan (SKL) sebagaimana yang dimaksud oleh PP nomor 19 tahun 2005, Pasal 1 ayat (4) adalah kualifikasi kemampuan lulusan yang mencakup sikap, pengetahuan dan keterampilan. Standar kompetensi lulusan pada satuan pendidikan menengah umum bertujuan untuk meningkatkan kecerdasan, pengetahuan, kepribadian, akhlak mulia, serta keterampilan untuk hidup mandiri dan mengikuti pendidikan lebih lanjut.

d. Standar Pendidikan dan Tenaga kependidikan

Pendidik harus memiliki kualifikasi akademik dan kompetensi sebagai agen pembelajaran, sehat jasmani dan rohani, serta memiliki kemampuan untuk mewujudkan tujuan pendidikan nasional. Pendidik pada SMA/MA dan SMK harus memiliki : (a) kualifikasi akademik pendidikan minimum diploma empat (DIV) atau sarjana (S1), (b) latar belakang pendidikan tinggi dengan program pendidikan yang sesuai dengan mata pelajaran yang diajarkan; dan (c) sertifikat profesi guru. Sedangkan tenaga kependidikan untuk SMA/MA dan SMK sekurang-kurangnya terdiri atas kepala sekolah, tenaga administrasi, tenaga perpustakaan, tenaga laboratarium, dan tenaga kebersihan sekolah. 
e. Standar Sarana dan Prasarana

Standar sarana dan prasarana adalah standar nasional pendidikan yang berkaitan dengan kriteria minimal tentang ruang belajar, tempat berolah raga, tempat beribadah, perpustakaan, laboratarium, bengkel kerja, tempat bermain, tempat berkreasiserta sumber belajar lain, yang diperlukan untuk menunjang proses pembelajaran, termasuk menggunakan teknologi informasi dan komunikasi. Standar ini disusun dan dikembangkan oleh Badan Standar Nasional Pendidikan dan ditetapkan oleh Keputusan Menteri Pendidikan Nasional. Hal ini selanjutnya diatur dalam Permendiknas nomor 24 Tahun 2007 tentang standar sarana dan prasarana untuk sekolah dasar/madrasah ibtidaiyah (SD/MI), sekolah menengah pertama/madrasah tsanawiyah (SMP/MTs), dan sekolah menengah Aaas/madrasah aliyah (SMA/MA).

f. Standar Pengelolaan

Didalam Peraturan Pemerintah nomor 19 tahun 2005 Bab VIII Pasal 49-61 menjelaskan bahwa pengelolaan satuan pendidikan pada jenjang pendidikan dasar dan menengah menerapkan manajemen berbasis sekolah yang ditunjukan dengan kemandirian,kemitraan, partisipasi, keterbukaan, dan akuntabilitas. Setiap satuan pendidikan harus memiliki pedoman yang mengatur tentang : (a) kurikulum tingkat satuan pendidikan dan silabus; (b) kalender pendidikan dan akademik; (c) struktur organisasi satuan 
pendidikan; (d) pembagian tugas diantara pendidik; (e) pembagian tugas diantara tenaga kependidikan; (f) peraturan akademik; (g) tata tertib satuan pendidikan, yang minimal meliputi tata tertib pendidik, tenaga kependidikan dan peserta didik, serta penggunaan dan pemeliharaan sarana dan prasarana.; (h) kode etik hubungan antara sesama warga didalam lingkungan satuan pendidikan dan hubungan antara wargasatuan pendidikan dengan masyarakat.; (i) biaya operasional satuan pendidikan. Selain itu setiap satuan pendidikan dikelola atas dasar rencana kerja tahunan yang merupakan penjabaran rinci dari rencanakerja jangka menengah satuan pendidikan yang meliputi masa 4 (empat) tahun.

g. Standar Pembiayaan

Standar pembiayaan adalah standar yang mengatur komponen dan besarnya biaya operasi satuan pendidikan yang berlaku dalam satu tahun. Standar pembiayaan pendidikan terdiri atas biaya investasi, biaya operasional, dan biaya personal. Biaya investasi meliputi biaya penyediaan sarana prasarana, pengembangan sumberdaya manusia, dan modal kerja tetap. Biaya operasional meliputi biaya pendidikan yang harus dikeluarkan oleh peserta didik untuk bisa mengikuti proses pembelajaran secara teratur dan berkelanjutan. Biaya operasional satuan pendidikan meliputi gaji pendidik dan tenaga kependidikan serta tunjangan yang melekat pada gaji, bahan atau peralatan pendidikan habis pakai dan biaya 
operasi pendidikan langsung berupa daya, air, jasa telekomunikasi, pemeliharaan sarana dan prasarana, uang lembur, transportasi, konsumsi, pajak, asuransi, dan lain sebagainya.

h. Standar Penilaian

Standar penilaian pendidikan adalah standar nasional pendidikan yang berkaitan dengan mekanisme, prosedur dan instrumen penilaian hasil belajar peserta didik. Penilaian hasil belajar oleh pendidik dilakukan secara berkesinambungan untuk memonitor proses, kemajuan, dan perbaikan hasil dalam bentuk ulangan harian, ulangan tengah semester, ulangan semester, dan ulangan kenaikan kelas.

\section{Perencanaan Strategis Peningkatan Mutu}

Mutu menjadi bagian penting dari strategi institusi dan harus didekati secara sistematis dengan menggunakan proses perencanaan strategis. Perencanaan strategis merupakan salah satu bagian dari total quality management. Tanpa arahan jangka panjang yang jelas, sebuah institusi tidak dapat merencanakan peningkatan mutu. ${ }^{54}$

Peningkatan mutu di lembaga pendidikan adalah suatu proses yang sistematis yang secara terus menerus meningkatkan kualitas proses belajar mengajar dan faktor-faktor yang berkaitan dengan tujuan agar target sekolah dapat dicapai secara efektif dan efisien. ${ }^{55}$

\footnotetext{
${ }^{54}$ Edward Sallis, Total Quality Management in Education: Manajemen Mutu Pendidikan, (Jogjakarta: IRCiSoD, 2012), 211-212.

${ }^{55}$ Zamroni, Meningkatkan Mutu Sekolah (Jakarta: PSAP Muhammadiyah, 2007), hlm. 7.
} 
Oleh karena itu, perencanaan strategik dalam meningkatkan mutu pendidikan di lembaga pendidikan adalah suatu rencana yang komprehensif dengan melibatkan segala sumber dan kemampuan untuk meningkatkan kualitas proses belajar mengajar, mencapai tujuan lembaga memenangkan kompetisi dan adaptif terhadap pengaruh eksternal dan internal.

Perencanaan strategis peningkatan mutu pada sekolah didasarkan pada kelompok-kelompok pelanggan dan harapan-harapan mereka yang bervariasi, kemudian mengembangkan kebijakan-kebijakan serta pencapaian misi danvisi. Rencana strategis sekolah merinci pada tolak ukur yang kelak dapat digunakan untuk mencapai misinya. ${ }^{56}$

Perencanaan strategis peningkatan mutu dalam implementasinya tidak bisa lepas dari manajemen peningkatan mutu pendidikan. Berkaitan dengan ini, Usman mengatakan bahwa manajemen peningkatan mutu memiliki prinsip yaitu: a) peningkatan mutu harus dilaksanakan di sekolah, b) peningkatan mutu hanya dapat dilaksanakan dengan adanya kepemimpinan yang baik, c) peningkatan mutu harus didasarkan pada data dan fakta baik bersifat kualitatif maupun kuantitatif, d) peningkatan mutu harus memberdayakan dan melibatkan semua unsur yang ada di sekolah, e) peningkatan mutu memiliki tujuan bahwa sekolah dapat memberikan kepuasan kepada siswa, orang tua dan masyarakat. ${ }^{57}$

\footnotetext{
${ }^{56}$ Edward Sallis, Total Quality Management in Education: Manajemen Mutu Pendidikan, (Jogjakarta: IRCiSoD, 2012), 226.

${ }^{57}$ Husaini Usman, Manajemen: Teori, Praktik \& Riset Pendidikan, (Jakarta: Bumi Aksara, 2008), hlm. 18 .
} 
Perencanaan strategis disusun dengan tujuan untuk memberikan sebuah pedoman dan arahan kepada institusi. Akan tetapi, rencana tersebut bukan merupakan instrumen yang kaku, tetapi harus dimodifikasi jika peristiwa membutuhkannya baik internal maupun eksternal. Analisis misi, nilai-nilai, SWOT dan faktor penting kesuksesan yang telah dilakukan, maka rencana strategis harus segera mengarahkan sejumlah isu-isu kunci yang muncul.

Dari penjelasan diatas disimpulkan bahwa perencanaan strategis yang terarah dan dilaksanakan secara utuh oleh semua pihak sekolah akan mampu meningkatkan mutu pendidikan sesuai dengan yang diharapkan dan dengan perencanaan strategis sekolah akan mampu mengetahui strategi-strategi dan metode apa saja yang dilakukan untuk memenuhi kebutuhan stakeholders kedepannya dan juga mampu menghadapi faktor-faktor yang dapat menghambat peningkatan mutu pendidikan. 


\section{BAB III}

\section{METODE PENELITIAN}

\section{A. Pendekatan dan Jenis Penelitian}

Fokus penelitian ini adalah implementasi perencanaan strategis dalam meningkatkan mutu pendidikan di SMK Al-Falah Moga Pemalang. Untuk menjawab fokus penelitian tersebut dibutuhkan sub-fokus yang mempertanyakan mengenai proses penyusunan perencanaan strategis, strategi implementasi perencanaan strategis dan evaluasi perencanaan strategis dalam meningkatkan mutu pendidikan.

Penelitian ini menggunakan pendekatan penelitian kualitatif.Penelitian ini bertujuan untuk meneliti secara mendalam dan menganalisis data secara menyeluruh mengenai implementasi perencanaan strategis dalam meningkatkan mutu pendidikan di SMK Al-Falah Moga Pemalang.

Penelitian kualitatif ini menurut Schatzman dan Strauss yang dikutip oleh Sugiyono (2006) adalah metode penelitian yang bertujuan untuk memperoleh pemahaman tentang kenyataan social melalui proses berpikir induktif dimana ada keterlibatan peneliti dalam situasi dan fenomena yang diteliti. ${ }^{58}$ Penelitian kualitatif memiliki enam ciri yaitu: (1) memperhatikan konteks dan situasi, (2) berlatar alamiah, (3) manusia sebagai instrument

\footnotetext{
${ }^{58}$ Sugiyono, Metode Penelitian Kualitatif R dan D, (Bandunf: Alfabeta, 2006), hlm. 17
} 
utama, (4) data bersifat deskriptif, (5) rancanagan penelitian muncul bersamaan dengan pengamatan, (6) analisis data secara induktif. ${ }^{59}$

Sedangkan jenis penelitian ini adalah studi kasus. Menurut Bogdan dan Biklen studi kasus adalah suatu strategi penelitian yang mengkaji secara rinci suatu latar atau satu objek atau satu tempat penyimpanan dokumen atau suatu peristiwa tertentu. Studi kasus memiliki tujuan untuk memberikan gambaran secara mendetail tentang latar belakang, sifat-sifat serta karakterkarakter yang khas dari kasusyang kemudian dijadikan suatu hal yang bersifat umum. Dalam penelitian ini peneliti menggunakanstudi kasus dengan satu latar penelitian di SMK Al-Falah Moga Kabupaten Pemalang terkait dengan implementasi perencanaan strategis terhadap peningkatan mutu pendidikan.

\section{B. Lokasi Penelitian}

Sesuai dengan judul yang ada, penelitian ini dilakukan di SMK AlFalah Moga Kabupaten Pemalang yang beralokasikan di Jalan Raya Moga Guci Km 0.5 Banyumudal Moga Pemalang Jawa Tengah.

SMK Al-Falah Moga Kabupaten Pemalang adalah salah satu sekolah yang didirikan karena adanya program dari pemerintah untuk mendirikan SMK kelas jauh di pondok pesantren. Namun sejak tahun 2005, SMK AlFalahMoga Kabupaten Pemalang telah menjadi SMK mandiri yang berbasis Ahlussunnah waljamaah.Sengaja peneliti meneliti di SMK Al-Falah Moga Pemalang, sebab dari beberapa informasi dan dari hasil survey, sekolah yang sudah berdiri pada tahun 2005sudah mengalami kemajuan yang signifikan

${ }^{59}$ Donal Ary, An Invitation To Research In School Education (Bacerly Hills: Sage Publication, 2002), hlm. 424 
dan mendapat kepercayaan dari masyarakat, terbukti dari semakin meningkatnya jumlah peserta didik dan mitra kerja dari dunia usaha dan dunia industri baik lokal, nasional, ataupun internasional.

\section{Kehadiran Peneliti}

Penelitian kualitatif merupakan penelitian yang menekankan pada hasil pengamatan peneliti, sehingga peneliti menyatu dengan situasi dan fenomena yang diteliti. ${ }^{60}$ Kehadiran peneliti adalah salah satu unsur penting dalam penelitian kualitatif. Peneliti merupakan perencana, pelaksana, pengumpul data, dan pada akhirnya menjadi pelopor penelitiannya. ${ }^{61}$ Bahkan dalam penelitian kualitatif ini posisi peneliti menjadi instrumen kunci (the key instrument). ${ }^{62}$

Oleh karena itu, sebagai instrumen kunci, peneliti hadir secara intensif sesuai dengan rencana penelitian, untuk memahami fokus penelitian secara holistik. Hal ini menciptakan akurasi data mengenai perencanaan strategis yang menjadi fokus penelitian. Untuk memperoleh data yang diinginkan dengan mudah dan lengkap, peneliti harus membangun kepercayaan yang tinggi dan menghindarkan kesan-kesan yang merugikan informan. Kehadiran peneliti di lapangan harus diketahui secara terbuka oleh subyek penelitian.

${ }^{60}$ Nana Syaudih Sukmadinata, Metode Penelitian Pendidikan (Bandung: Remaja Rosdakarya, 2009), hlm. 95.

${ }^{61}$ Lexi J. Moeloeng, Metodologi Penelitian Kualitatif (Bandung: Remaja Rosdakarya, 2006), hlm. 162.

${ }^{62}$ Sugiono, Metode Penelitian Kuantitatif, Kualitatif, dan R\&D (Bandung: Alfabeta, 2008), hlm. 233. 


\section{Data dan Sumber Data}

Data merupakan keterangan-keterangan tentang suatu hal, dapat berupa sesuatu yang diketahui, yang dianggap atau anggapan.Atau suatufakta yang digambarkan lewat angka, simbol, kode dan sebagainya.Sumber data utama dalam penelitian kualitatif ialah kata-kata dan tindakan, selebihnya adalah data tambahan seperti dokumen dan lain-lain. ${ }^{63}$

Selain itu menurut cara memperolehnya, data dikategorikan menjadi dua jenis yaitu, data primer dan data sekunder. Data primer adalah data yang diperoleh, diolah dan disajikan peneliti dari sumber utama. Sedangkan data sekunder adalah data yang diperoleh, diolah dan disajikan oleh pihak lain atau biasanya dalam bentuk publikasi atau jurnal. ${ }^{64}$

Data primer yang akan digunakan dalam penelitian ini yaitu berupa data verbal dari hasil wawancara dengan para informan yang kemudian peneliti catat dalam bentuk catatan tertulis, rekaman dengan menggunakan recorder, serta pengambilan foto. Sedangkan data dari pengamatan langsung akan peneliti catat dalam bentuk catatan lapangan.

Data-data primer akan peneliti peroleh dari para informan dengan teknik pemilihan informan yang bersifat purposive, artinya informan yang dipilih adalah orang-orang yang berkompeten (dianggap tahu) atau berkaitan baik secara langsung maupun tidak langsung dengan fokus penelitian. Adapun informan tersebut meliputi:

${ }^{63}$ Lexi J. Moeloeng, Metodologi Penelitian Kualitatif (Bandung: Remaja Rosdakarya, 2006), hlm. 6

${ }^{64}$ Hadari Nawawi dan Mimi Martiwi, Penelitian Terapan(Jakarta: Rieneka Cipta, 2002), hlm: 107 
1. Kepala Sekolah SMK Al-Falah Moga Kabupaten Pemalang yang paling berpengaruh dalam perkembangan pendidikan lembaga yang dipimpinnya.

2. Waka kurikulum, kesiswaan, dan Humas SMK Al-Falah Moga Kabupaten Pemalang.

3. Guru SMK Al-Falah Moga Kabupaten Pemalang.

Selain itu, data primer yang berupa dokumen adalah dokumen-dokumen SMK Al-Falah Moga Kabupaten Pemalang yang berkaitan dengan fokus penelitian, misalnya dokumen sejarah sekolah, data guru, data siswa, data sarana dan prasarana, program kerja sekolah, Rencana Anggaran dan Belanja Sekolah dan lain sebagainya.

Adapun data sekunder yang akan digunakan dalam penelitian ini yaitu jurnal-jurnal maupun tulisan yang dipublikasikan melalui internet yang ditulis oleh orang lain yang berkaitan dengan implementasi perencanaan strategis.

\section{E. Teknik Pengumpulan Data}

Ada beberapa teknik pengumpulan data, teteapi dalam penelitian ini yang digunakan ialah teknik wawancara, observasi, dan dokumentasi.

1. Wawancara

Wawancara dilakukan secara mendalam (in depth interview wing), guna memperoleh informasi secara mendalam. ${ }^{65}$ Dilakukan untuk mendapatkan informasi dengan cara bertanya langsung pada responden. ${ }^{66}$

\footnotetext{
${ }^{65}$ Sutopo, HB,Metode Penelitian Kualitatif, Metode Penelitian Untuk Ilmu-ilmu Sosial dan Budaya (surakarta: UNS, 1996), hlm. 50.

${ }^{66}$ Masri Singarimbun dan Sofyan Effendi, Metode Penelitian Survey, (Jakarta: LP3ES, 1994), hlm. 192
} 
Selain itu dilakukan tidak secara formal, dengan maksud untuk menggali pandangan, motivasi, perasaan dan sikap dari informan. ${ }^{67}$

Dalam penelitian ini peneliti memperoleh informasi dari kepala sekolah yang berperan secara langsung dalam implementasi perencanaan strategis di SMK Al-Falah Moga Kabupaten Pemalang dan beberapa waka, guruuntuk memperoleh informasi yang berkaitan dengan implementasi perencanaan strategis di SMK Al-Falah Moga Kabupaten Pemalang.

Wawancara dari segi pelaksanaannya dibedakan menjadi tiga, yaitu: ${ }^{68}$

1) Wawancara bebas, dimana pewawancara bebas menanyakan apa saja yang berhubungan dengan penelitian yang dilakukan

2) Wawancara terpimpin, wawancara yang dilakukan dimana pewawancara membawa sederetan pertanyaan lengkap dan terperinci

3) Wawancara bebas terpimpin, kombinasi antara wawancara bebas dan terpimpin.

Mengacu pada penjelasan di atas, dalam penelitian ini peneliti menggunakan teknik wawancara bebas terpimpin, dimana peneliti membawa sederetan pertanyaan dan juga menanyakan hal-hal lain yang terkait dengan penjelasan yang telah dipaparkan oleh subyek penelitian.

Wawancara ini digunakan untuk mewawancarai misalnya kepala sekolah, waka, dan guru.

\footnotetext{
${ }^{67}$ Lukas, Masalah Wawancara dengan Informan Pelaku Sejarah di Jawa. Aspek Manusia dalam Penelitian Masyarakat, (Jakarta: Gramedia, 1992), hlm 211-214.

${ }^{68}$ Suharsimi Arikunto, Prosedur Penelitian, Suatu Pendekatan Praktek, (Jakarta: Rineka Cipta, 2002), hlm. 132.
} 
Namun disini peneliti juga menggunakan metode wawancara bebas, yang peneliti tidak menggunakan pedoman wawancara yang tersusun rapi. Wawancara bebas ini dilakukan dengan maksud agar responden tidak merasa canggung dalam menyampaikan pendapatnya. Misalnya melakukan wawancara terhadap petugas perpustakaan, satpam, penjaga sekolah, dan lain-lain. Dan pedoman wawancara yang digunakan hanya berupa garis besar permasalahan yang dinyatakan.

Cara pengambilan sampel yang digunakan adalah purposive sampling, atau sering disebut dengan internal sampling, yaitu sampel atau informan yang dipilih bukan untuk mewakili populasi tapi mewakili informasinya dan masalahnya secara mendalam sehingga dapat dipercaya untuk menjadi sumber data yang mantap. ${ }^{69}$ Metode pengumpulan data ini peneliti gunakan untuk memperoleh data tentang proses penyusunan, strategi implementasi, dan evaluasi perencanaan strategis di sekolah,dengan menggunakan model implementasi perencanaan strategis organisasi pendidikan secara teoritik sebagai acuan. Dalam hal ini peneliti melakukan wawancara secara mendalam dengan pihak-pihak penyelenggara pendidikan di sekolah, yaitu: kepala sekolah (sebagai informasi kunci), beberapa waka, dan guru sekolah mengenai implementasi perencanaan strategis pada lembaga yang dikelolanya.

Dipilihnya cara ini karena didasarkan atas pertimbangan bahwa penelitian ini adalah merupakan studi kasus, sehingga bukan hanya 
sekedar menetapkan siapa yang diobservasi, diwawancarai, tetapi juga menetapkan konteksnya, kejadiannya dan prosesnya. ${ }^{70}$ Oleh karena itu pemilihan informan dapat berkembang sesuai dengan kebutuhan dan kemantapan peneliti dalam memperoleh data.

2. Observasi

Observasi dilakukan secara langsung terfokus dan selektif. ${ }^{71}$ Sebagai metode ilmiah, observasi diartikan sebagai pengamatan dan pencatatan terhadap fenomena yang diselidiki. ${ }^{72}$ Sedangkan Kartini Kartono mengatakan bahwa observasi adalah studi yang disengaja dan sistematis tentang fenomena sosial dan gejala-gejala alam dengan jalan pengamatan dan pencatatan. ${ }^{73}$ Dalam metode ini peneliti menggunakan teknik observasi non partisipan, artinya peneliti tidak ikut dalam proses kegiatan yang dilakukan hanya mengamati dan mempelajari kegiatan dalam rangka memahami, mencari jawaban dan mencari bukti terhadap aktivitas dan efektivitas implementasi manajemen sumber daya manusia.

Di samping itu, metode observasi digunakan peneliti dalam kaitannya dengan mengumpulkan data tentang gambaran umum sekolah, seperti gedung sekolah, masjid, perpustakaan, kantor dan sebagainya. Selain itu, informasi-informasi lainnya sebagai pelengkap penelitian. Dalam hal ini peneliti mendatangi sekolah guna memperoleh data yang

\footnotetext{
${ }^{70}$ Noeng Muhadjir, Metodologi Penelitian Kualitatif, (Yogyakarta: Raka Sarasin, 1989), hlm. 40 ${ }^{71}$ Nasution, Metodologi Penelitian Naturalistik Kualitatif (Bandung: Tarsito, 1996), hlm. 63.

${ }^{72}$ Sutrisno Hadi, Metodologi Research II, (Yogyakarta : Andi Offset, 1994), hlm. 136

${ }^{73}$ Kartini Kartono, Pengantar Metodologi Research Sosial, (Bandung : CV. Mandar Maju, 1990), hlm. 157
} 
konkrit tentang hal-hal yang menjadi obyek penelitian, selain untuk melihat dan mengamati langsung dari dekat kegiatan Sekolah.

Observasi ini untuk mengawasi peristiwa yang terjadi pada situs penelitian. Program strategis yang sudah ditetapkan apakah benar sudah dilaksanakan dilihat kenyataannya secara langusung. Pencatatan dokumen dilakukan untuk mengidentifikasi dan menganalisis secara kritis rencana strategis yang ada baik dokumen dari proses penyusunannya, analisis yang digunakan sampai pada implementasinya dan sumbangannya terhadap kemajuan sekolah.

3. Dokumentasi

Dokumentasi adalah suatu teknik di mana data diperoleh dari dokumen-dokumen yang ada pada benda-benda tertulis seperti bukubuku notulensi, makalah, peraturan-peraturan, buletin-buletin, catatan harian dan sebagainya. ${ }^{74}$ Sedangkan pengumpulan data yang dilakukan dalam penelitian ini yaitu untuk memperoleh data yang terkait dengan implementasi perencanaan strategis di SMK Al-Falah Moga Kabupaten Pemalang dan data lainnya yang mendukung atau dibutuhkan dalam penelitian ini.

${ }^{74}$ Suharsimi Arikunto, Prosedur Penelitian: Suatu Pendekatan Praktek(Edisi Revisi IV) (Jakarta: PT. Rineka Cipta, 2006), hlm. 135. 


\section{F. Analisis Data}

Data yang berhasil dikumpulkan, dianalisis dengan menggunakan model analisis interaktif. ${ }^{75}$ Dalam model analisis ini, terdapat tiga komponen analisisnya, yaitu reduksi data, sajian data, dan penarikankesimpulan/verifikasi dilaksanakan bersamaan dengan proses pengumpulan data dalam bentuk interaktif melalui proses siklus.

Data yang diperoleh dari lapangan jumlahnya cukup banyak, untuk itu maka data perlu dicatat secara teliti dan rinci. Kemudian data dirangkum, dipilih hal-hal yang pokok, difokuskan pada hal-hal yang penting dan dicari tema serta polanya. Data yang telah direduksi akan memberikan gambaran yang lebih jelas dan mempermudah peneliti untuk melakukan pengumpulan data selanjutnya, dan mencari data berikutnya jika diperlukan. Data-data yang tidak terpakai dibuang, sehingga peneliti lebih fokus pada data yang telah tereduksi. $^{76}$

Reduksi data didasarkan pada relevansi dan kecukupan informasi untuk menjelaskan implementasi perencanaan strategis yang ada di sekolah, selanjutnya dianalisis dan dihubungkan dengan metode dalam proses penyusunan, strategi implementasi, dan evaluasi perencanaan strategis di sekolah. Oleh karena itu, peneliti memilih data yang relevan dan bermakna yang akan peneliti sajikan. Peneliti melakukan seleksi dan memfokuskan data

\footnotetext{
${ }^{75}$ Mattew B. Miles dan A. Michele Haberman, An Expanded Sourcebook Qualitative Data Analysis, Second Edition, terj. Tjetjep R. Rohidi,, Analisis Data Kualitatif(Jakarta : UI-Press, 1992), hlm. 23

${ }^{76}$ Mattew B. Miles dan A. Michele Haberman, An Expanded Sourcebook Qualitative Data Analysis, Second Edition, terj. Tjetjep R. Rohidi,, Analisis Data Kualitatif (Jakarta : UI-Press, 1992), hlm. 96.
} 
yang mengarah untuk menjawab pertanyaan penelitian, kemudian menyederhanakan dan menyusun secara sistematis dengan menonjolkan halhal yang dianggap penting dari hasil temuan yang berkaitan dengan implementasi perencanaan strategis di SMK Al-Falah Moga Kabupaten Pemalang, dengan melihat konsep perencanaan strategis secara teoritik.

Reduksi data dalam penelitian ini hakikatnya adalah menyederhanakan dan menyusun secara sistematis data dari lapangan dalam dimensi perencanaan strategis di sekolah.

Adapun yang dijadikan pedoman dalam proses analisis data, dapat dikemukakan sebagai berikut:

a. Hasil wawancara, observasi, pencatatan dokumen, dibuat catatan lapangan secara lengkap, catatan ini terdiri dari deskriptif dan refleksi mengenai implementasi perencanaan strategis di sekolah.

b. Berdasarkan catatan lapangan, selanjutnya dibuat reduksi data. Reduksi data ini berupa pokok-pokok temuan yang penting tentang implementasi perencanaan strategis di sekolah.

c. Reduksi data kemudian diikuti penyusunan sajian data berupa cerita sistematis dengan suntingan peneliti supaya maknanya lebih jelas dipahami. Sajian data ini, dilengkapi dengan faktor pendukung antara lain metode, skema, bagan tabel dan sebagainya.

d. Berdasarkan sajian data tersebut, kemudian dirumuskan kesimpulan sementara atau sering disebut temuan penelitian. 
e. Kesimpulan sementara tersebut senantiasa akan terus berkembang sejalan dengan penemuan data baru, sehingga akan didapat suatu kesimpulan yang mantap dan benar-benar sesuai dengan keadaan yang sebenarnya.

Demikian seterusnya, aktivitas penelitian ini berlangsung, yaitu terjadi interaksi yang terus menerus antara ketiga komponen analisisnya bersamaan dengan pengumpulan data baru yang dirasakan bisa menghasilkan data yang lengkap sehingga dapat dirumuskan kesimpulan akhir.

\section{G. Pengecekan Keabsahan Data}

Pengecekan keabsahan temuan dilakukan agar memperoleh hasil yang valid dan dapat dipertanggungjawabkan serta dipercaya oleh semua pihak. Dalam penelitian ini, peneliti menggunakan pengecekan keabsahan temuan dengan triangulasi sumber dan triangulasi teknik.

Triangulasi sumber adalah membandingkan dan mengecek balik derajat kepercayaan suatu informasi yang diperoleh melalui waktu dan alat yang berbeda dalam metode kualitatif. Dalam hal ini, peneliti berusaha membandingkan data dari hasil wawancara, hasil pengamatan dan data dokumentasi.

Triangulasi teknik adalah untuk menguji kredibilitas data yang dilakukan dengan cara mengecek data dengan sumber yang sama. Dalam 
penelitian ini, peneliti berusaha membuktikan data hasil wawancara denganobservasi dan dokumentasi. ${ }^{77}$

Dengan demikian, peneliti disini selalu hati-hati dalam penggalian data dan selalu fokus dalam melakukan penelitian. Disamping itu, peneliti selalu membandingkan atau menindaklanjuti temuan (data) yang diperoleh dari sumber yang satu terhadap sumber yang lain.

${ }^{77}$ Lexi J. Moeloeng, Metodologi Penelitian Kualitatif (Bandung: Remaja Rosdakarya, 2006), hlm. 178. 


\section{BAB IV}

\section{PAPARAN DATA DAN TEMUAN PENELITIAN}

Pada bab ini peneliti memaparkan data dan temuan penelitian di lapangan mengenai implementasi perencanaan strategis di SMK Al-Falah dalam meningkatkan mutu pendidikan. Dengan fokus penelitian pada proses penyusunan perencanaan strategis dalam meningkatkan mutu pendidikan di SMK Al-Falah, strategi implementasi perencanaan strategis dan evaluasi implementasi perencanaan strategis terhadap mutu pendidikan di SMK Al-Falah Moga Kabupaten Pemalang.

\section{A. GAMBARAN UMUM LOKASI PENELITIAN}

\section{Sejarah Singkat SMK Al-Falah Moga Pemalang}

SMK Al-Falah merupakan sekolah yang terlahir dengan adanya program pemerintah untuk mendirikan SMK Kecil/Kelas Jauh di Pondok Pesantren, yakni dibawah naungan pondok pesantren Al-Falah. Sesuai dengan SK Bupati Pemalang Nomor 421.5/12/2005 tentang pendirian Sekolah Menengah Kejuruan, sejak saat itu, SMK Al-Falah resmi menjadi sekolah mandiri. Kepemimpinan SMK AL-Falah Moga terhitung dari tahun 2005 sampai sekarang masih dipegang oleh Drs. Rujito Dw.

\section{Identitas Sekolah}

Nama Sekolah

: SMK Al-Falah Moga Kabupaten Pemalang

Kepala Sekolah : Drs. Rujito Dw.

Alamat Sekolah $\quad$ : Jl. Raya Moga Karangsari Km 0.5 Banyumudal 
Email :smk_alfalahmoga@yahoo.com

$\mathrm{B} \log$ : www.smkalfalahmoga.sch.id

\section{Visi, Misi Dan Tujuan SMK Al-Falah Moga Pemalang}

a. Visi

"Membangun sumber daya manusia beriman, bertaqwa, terampil, mandiri dan profesional".

b. Misi

1) Meningkatnya keimanan dan ketaqwaan kepada Allah SWT bagi civitas akademika SMK Al-Falah Moga

2) Terjalin hubungan yang harmonis, seimbang, dan berkesinambungan dalam hubungan manusia dengan manusia, manusia dengan Tuhannya, dan manusia dengan alam sekitarnya.

3) Membekali pengetahuan, sikap dan ketrampilan pada siswa untuk hidup mandiri dan profesional.

4) Menumbuhkembangkan sikap dan perilaku kompetetif dikalangan siswa agar hidup sehat dan berkualitas.

c. Tujuan

1) Mewujudkan SMK Al-Falah Moga sebagai lembaga pendidikan dan kepelatihan yang mampu mengoptimalkan sumber daya manusia dan sumber daya alam.

2) Membekali peserta didik yang mempunyai etos kerja dengan standar nasional. 
3) Memanfaatkan sumber daya modal yang ada untuk mengoptimalkan penyelenggaraan pendidikan.

4) Terwujudnya penyelenggaraan pendidikan pondok pesantren dengan pendidikan formal sebagai model dalam mempersiapkan peserta didik menjadi sumberdaya manusia yang berkualitas.

\section{Data Guru Dan Karyawan SMK Al-Falah Moga Pemalang}

Guru merupakan orang yang bertanggung jawab dalam pelaksanaan, proses belajar mengajar di kelas, guru berkewajiban menyajikan dan menjelaskan materi pelajaran, membimbing dan mengarahkan siswa kearah pencapaian tujuan pengajaran yang telah dicanangkan. Dalam hal ini dibutuhkan kemampuan dan profesionalisme guru dalam melaksanakan tugas-tugasnya.

Tenaga pengajar dan pegawai yang dimiliki SMK Al-Falah telah mampu memenuhi kebutuhan dalam pelaksanaan pendidikan sesuai dengan kebutuhan lembaga. keadaan guru di SMK Al-Falah sebanyak 70 orang terdiri dari 54 orang guru, dan pegawai sebanyak 16 orang.

\section{Data Siswa SMK Al-Falah Moga Pemalang}

Dalam proses belajar mengajar, siswa menduduki peranan yang sangat penting. Karena siswa menjadi tolak ukur berhasil tidaknya proses belajar mengajar. Oleh karena itu keberadaan dan peran aktif siswa mutlak diperlukan dalam proses belajar mengajar. Keaadan siswa SMK Al-Falah Moga memiliki 5 bidang keahlian, yaitu bidang keahlian ahribisnis dan agroteknologi, bidang keahlian tehnik kendaraan ringan, bidang keahlian 
tata busana, bidang keahlian tehnik dan bisnis sepeda motor, dan bidang keahlian akuntansi. Dalam hal jumlah penerimaan siswa pada tahun pelajaran 2017/2018 SMK Al-Falah Moga menerima 625 siswa baru.

\section{B. PAPARAN DATA PENELITIAN}

1. Proses Penyusunan Perencanaan Strategis Sekolah Dalam Meningkatkan Mutu Pendidikan di SMK Al-Falah Moga

Proses penyusunan perencanaan strategis SMK Al-Falah Moga Pemalang adalah dengan melakukan beberapa langkah diantaranya adalah: pertama, merumuskan visi, misi, dan tujuan sekolah; kedua,kemudian membentuk satgas penyusun perencanaan strategis; ketiga,proses perumusan; dan keempat,penetapan perencanaan strategis tersebut.

Visi, misi dan tujuan sekolah merupakan landasan konseptual lembaga dan merupakan cita-cita, arah dan mimpi yang merupakan idealisme bersama.Oleh karena itu dalam perumusannya tidak boleh terlepas dari prinsip kebersamaan atau demokrasi dan didasarkan pada hasil pemikiran yang rasional serta tidak menyimpang dari peraturan dan visi, misi dan tujuan pendidikan nasional.

Dalam penyusunan visi, misi, dan tujuan sekolah dilakukan dengan menyelenggarakan rapat atau musyawarah bersama seluruh komponen sekolah yang terdiri dari yayasan, dewan guru, dan komite. Sebagaimana dikatakan oleh Kepala Sekolah dalam wawancara:

"Mengenai penyusunan visi, misi, dan tujuan di SMK Al-Falah Moga Pemalang ditentukan dan ditetapkan dalam rapat koordinasi yang 
melibatkan yayasan, dewan guru, komite. Jadi visi, misi dan tujuan yang ada, merupakan hasil dari konstribusi mereka semua. Berhubung SMK ini berdiri di naungan pondok pesantren, beberapa pengasuh pondok pesantren Al-Falah pun ikut andil." 78

Visi dan misi SMK Al-Falah Moga Pemalang di susun dengan memperhatikan kebutuhan dan harapan stakeholders, karena dikatakan oleh kepala sekolah telah menghadirkan komite sekolah sebagai keterwakilan stakeholder stersebut.

"Adanya komite sekolah hadir, tentunya untuk memberikan kesempatan untuk menyampaikan apa yang menjadi harapan, kebutuhan dari stakeholders yang mana komite merupakan wakil dari orang tua siswa, tokoh masyarakat, dan tokoh pendidikan. "79

Diperkuat dengan data dokumentasi dari sejarah SMK Al-Falah Moga Pemalang mengenai penyusunan visi, misi dan tujuan sekolah diselenggarakan dengan rapat dan musyawarah, didasarkan pada hasil pemikiran dari kepala sekolah, komite sekolah, yaysan, dan pengasuh pondok pesantren Al-Falah Moga Pemalang. ${ }^{80}$

Berikut ini visi, misi dan tujuan yang telah dihasilkan SMK AlFalah Moga Pemalang ${ }^{81}$

\footnotetext{
${ }^{78}$ Wawancara Kepala Sekolah Bapak Rjito Dw, 16-11-2017

${ }^{79}$ Wawancara Kepala Sekolah Bapak Rjito Dw, 16-11-2017

${ }^{80}$ Dokumentasi Sejarah SMK Al-Falah Moga Pemalang

${ }^{81}$ Dokumentasi Visi, Misi, dan Tujuan Sekolah SMK Al-Falah Moga Pemalang
} 


\section{a. Visi SMK Al-Falah Moga Pemalang}

Terwujudnya sumber daya manusia yang beriman, bertaqwa, terampil, mandiri dan professional.

\section{b. Misi SMK Al-Falah Moga Pemalang}

1) Meningkatkan keimanan, ketaqwaan kepada Allah SWT civitas SMK Al-Falah Moga Pemalang.

2) Terjalin hubungan yang haronis, seimbang, dan kesinambungan dalam hubungan manusia dengan Tuhannya, manusia dengan manusia, dan manusia dengan alam sekitarnya.

3) Membekali pengetahuan, sikap dan keterampilan pada siswa untuk hidup mandiri dan professional.

4) Menumbuhkembangkan sikap dan perilaku kompetitif dikalangan siswa agar hidup sehat dan berkualitas.

c. Tujuan

1) Mewujudkan SMK Al-Falah Moga sebagai lembaga pendidikan dan pelatihan yang mampu mengoptimalkan sumber daya manusia dan sumber daya alam.

2) Membekali peserta didik yang mempunyai etos kerja dengan standar nasional.

3) Memanfaatkan sumber daya modal yang ada untuk mengoptimalkan penyelenggaraan pendidikan. 
4) Terwujudnya penyelenggaraan pendidikan pondok pesantren dengan pendidikan formal sebagai model dalam mempersiapkan pesrta didik menjadi sumber daya manusia yang berkualitas.

Visi dan misi yang ada ini merupakan gambaran dari kepercayaan sekolah untuk sebuah pencapaian dimasa mendatang, artinya visi misi itu menjadi impian bersama, merupakan sesuatu yang akan dicapai bersama di kemudian hari. Agar dapat dipahami dan dilaksanakan oleh seluruh komponen sekolah, dilakukan sosialisasi sekaligus internalisasi visi, misi dan tujuan sekolah dengan berbagai cara, diantaranya dibacakan pada saat upacara, kemudian dipasang di tempat-tempat strategis, Selain itu, di depan pintu masuk ditulis pada papan yang besar semacam baliho agar semua orang yang masuk SMK ini bisa membacanya dengan mudah. Sebagaimana dikatakan Kepala Sekolah;

"kita melakukan upaya sosialisasi visi, misi, dan tujuan sekolah dengan berbagai cara, daintaranya kita bacakan pada waktu masa orientasi siswa baru, upacara, dipasang di tempat-tempat strategis. Contoh saja, di depan pintu masuk dipasang baliho bertuliskan visi, misi, dan tujuan sekolah, dengan tujuan agar orang yang masuk SMK ini bisa membacanya dengan mudah." 82

Berdasarkan hasil observasi peneliti di lapangan memang benar bahwa di beberapa tempat strategis dan pintu gerbang sekolah terpampang cukup besar visi dan misi SMK Al-Falah Moga Pemalang. ${ }^{83}$

Setelah merumuskan visi, misi dan tujuan sekolah, langkah selanjutnya dalam menyusun perencanaan strategis adalah kepala sekolah 
membentuk satgas penyusun renstra. Satgas yang berjumlah Sembilan orang inilah yang ditugaskan untuk merumuskan rencana strategis. Sebagaimana dikatakan oleh kepala sekolah Drs. Rujito DW;

"Langkah-langkah penyusunan perencanaan strategik yang pertama dilakukan adalah membentuk satgas/tim atau mengumpulkan tim untuk mengagendakan mana strategi-strategi yang akan direncanakan kemudian rencana dari tahun yang sebelumnya yang terlaksana dan yang tidak terlaksana, serta dari yang terlaksana sudah cukupkan untuk kegiatan itu dilaksanakan lagi ditahun yang akan dating. Jadi semua waka dan kaprog saya libatkan dalam tim tersebut." 84

Satgas penyusun restra ditetapkan oleh Kepala Sekolah dengan susunan sebagai berikut:

$\begin{array}{lll}\text { Ketua } & \text { : Abdul Ghofar, S.Pd. } & \text { (Waka. Kurikulum) } \\ \text { Sekretaris } & \text { : Drs. Untung } & \text { (Waka Sarpras) } \\ \text { Anggota } & \text { : Gunaidi Priyono, S.Pd } & \text { (Waka Humas) } \\ & \text { Agus Pujiyanto, S.Pd } & \text { (Waka Kesiswaaan) } \\ & \text { Hafid Amaludin, S.Pd.T } & \text { (Kaprog. TKR) } \\ & \text { Imron, S.T } & \text { (Kaprog. TSM) } \\ & \text { Rahmi Yuliaeni, S.Pd } & \text { (Kaprog.Tata Busana) } \\ & \text { H. Imam Solikhul, S.P } & \text { (Kaprog. Agrobisnis) } \\ & \text { Okta Setiawan, S.Pd. } & \text { (Kaprog. Akuntansi) }\end{array}$

Tim perumus tersebut terdiri dari para wakil kepala sekolah dan para ketua program studi. Satgas yang sudah dibentuk tersebut kemudian melaksanakan tugasnya dengan menggali masukan dan aspirasi dari masing-masing bagian sesuai dengan tugasnya. Setelah mendapatkan 
masukan kemudian dikaji dan dirumuskan. Setelah semua masukan sudah terkumpul dan semua aspirasi terakomodir, maka satgas ini kemudian mengkaji dan merumuskan. Kemudian setelah rumusannya jadi, lalu diserahkan kepada kepala sekolah untuk disahkan bersama komite sekolah.

"Tim penyusunan perencanaan strategis yang biasanya dilakukan oleh sekolah kami adalah waka dan kaprog, mereka semua akan mencari masukan ataupun kebutuhan apa yang sesuai dengan bagiannya masingmasing.Nah setelah itu mereka akan merumuskan, setelah itu hasil akan saya tinjau kembali dan untuk pengesahan, saya bersama komite sekolah akan mengesahkan". 85

Selanjutnya Gunaidi Priyono, selaku Waka Humas menjelaskan bahwa:

"Jadi memang penyusunan renstra, atau dengan kata lain program kerja di SMK Al-Falah ini menggunakan metode demokrasi, jadi semua diberikan wewenang untuk memberikan masukan, bahkan kritik pun kita tampung. Saya diberikan wewenang oleh kepala sekolah khusunya dalam bidang humas. Setelah semua program kerja sudah saya susun, saya akan berikan ke kepala sekolah untuk dikaji ulang. Ada yang disetujui dan adapula yang tidak, tergantung kebutuhan sekolah pastinya. "86

Pada tahap proses perumusan ini sepenuhnya menjadi tugas tim perumus atau yang disebut dengan satgas penyusun perencanaan strategis. Sebagaimana telah disebutkan sebelumnya, satgas ini bekerja dalam kurun waktu satu bulan untuk menyelesaikan perencanaan srategis

SMK Al-Falah Moga Pemalang. Oleh ketua satgas yang juga wakil kepala sekolah bidang kurikulum Bapak Abdul Ghofar dikatakan bahwa dalam melaksanakan tugasnya dibagi menjadi dua minggu untuk proses

${ }^{85}$ Wawancara Kepala Sekolah Bapak Rjito Dw, 22-11-2017

${ }^{86}$ Wawancara Waka humas Bapak gunaidi Priyono, 12-01-2018 
pengumpulan masukan atau menggali aspirasi, dan dua minggunya lagi untuk proses pengkajian dan perumusan.

"Tim perumus yang berjumlah sembilan orang, oleh kepala sekolah diberi waktu satu bulan untuk menyelesaikan sampai menjadi rumusan yang sudah jadi, artinya sudah siap untuk ditetapkan. Sekitar bulan Mei-Juli.Sesuai dengan arahan bapak kepala sekolah, kita diminta untuk menggali masukan atau aspirasi dari bawah. Kita membuat semacam draf atau formulir untuk dibagikan pada masing-masing anggota satgas ini atau dengan cara wawancara, kemudian anggota satgas membagikan lagi kepada bagian-bagian dibawahnya. Untuk waktunya sendiri, dua minggu untuk mengumpulkan masukan-masukan itu, dan dua minggunya lagi untuk tahap pengkajian dan perumusan berdasarkan masukan-masukan yang ada. "87

Dalam mengumpulkan masukan-masukan atau menggali aspirasi semua unsur yang ada di sekolah diberikan kesempatan untuk mengusulkan program-program jangka pendek disesuaikan dengan visi, misi, dan tujuan SMK Al-Falah Moga Pemalang. Seperti yang diakatan oleh Abdul Ghofar;

"Contohnya saja saya dalam bidang kurikulum, saya akan menanyakan kepada masing-masing guru bidang studi kritik dan saran untuk program apa yang ingin dilaksanakan untuk satu tahun kedepan terkait dengan pengembangan kurikulum atau kegiatan belajar mengajar. " 88

Selanjutnya Agus Pujianto, S.Pd selaku Waka Kesiswaan, beliau mengatakan:

"Penyusunan perencanaan strategis menurut saya sangat penting sekali, apalagi untuk bidang kesiswaan sendiri. Contohnya saja, pertama tentang penerimaan siswa baru, program kegiatan di sekolah untuk siswa, dan masih banyak lagi hal-hal untuk pengembangan program kerja bidang kesiswaan. Khususnya dalam bidang kesiswaan saya akan menanyakan kepada beberapa guru kira-kira program apa yang akan

${ }^{87}$ Wawancara Waka Kurikulum Bapak Abdul Ghofur, 22-11-2017

${ }^{88}$ Wawancara Waka Kurikulum Bapak Abdul Ghofar, 22-11-2017 
dibuat untuk pengembangan siswa atau untuk beberapa event yang dilaksanakan oleh SMK Al-Falah." 89

Diperkuat dengan dokumentasi program kegiatan siswa, bahwa program kegiatan siswa yang dilakukan untuk tahun ajaran 2016/2017, antara lain: masa orientasi siswa baru, peringatan 17 Agustus 1945, peringatan hari raya idul adha, dan lain-lain..$^{90}$

Setelah proses pengumpulan atau proses menggali masukan dan aspirasi dianggap cukup, maka selanjutnya satgas penyusun rencana strategis SMK Al-Falah Moga Pemalang berkumpul untuk mengkaji program-program strategis yang diusulkan dari bawah, kemudia memilah dan memilih program yang sesuai dengan visi, misi sekolah dan disesuaikan juga dengan kondisi lingkungan sekolah baik internal maupun eksternal.

Setelah satgas penyusun perencanaan strategis menyelesaikan tugasnya, hasil dari rumusan perencanaan strategis menyelesaikan tugasnya, hasil dari rumusan perencanaan strategis tersebut selanjutnya diserahkan kepada kepala sekolah untuk disahkan bersama komite sekolah. Kepala sekolah setelah mendapatkan laporan hasil kerja dari satgas penyusun rencana strategis mempelajari rumusan tersebut. Kemudian apabila rumusan perencanaan strategis tersebut sudah dianggap bagus sesuai yang diharapkan maka dilanjutkan pada tahap pengesahan. 
Pada tahap ini kepala sekolah mengesahkan perencanaan strategis yang berbentuk Program Kerja Sekolah SMK Al-Falah Moga Pemalang periode 2016/2017 s.d 2017/2018 pada tanggal 07 Juli 2016. Kemudian perencanaan strategis yang telah secara resmi ditetepkan oleh kepala sekolah tersebut disosialisasikan baik secara formal pada saat rapat maupun informal. Sebagaimana dikatakan oleh Abdul Ghofar.

"Ketika program kerja sekolah sudah selesai dan dinyatakan fix maka selanjutnya dari pihak tim menyerahkan ke kepala sekolah guna untuk disetujui dan di koreksi, jika ada yang kurang maka dilakukan penambahan. Jika sudah dibenahi, setelah itu kepala sekolah mensosialisasikan kepada semua komponen sekolah baik secara formal maupun informal, contohnya saja pada rapat-rapat." 91

Selanjutnya Agus Pujianto selaku Waka Kesiswaan menambahkan, bahwa:

"Hasil dari rumusan program kerja bidang kesiswaan sudah tersusun, maka setelah itu saya serahkan kepala sekolah, untuk dikaji ulang, apakah program yang diajukan cocok dengan visi, misi dan tujuan sekolah, apakah program tersebut mendukung atas kemajuan mutu sekolah, apakah dibutuhkan sekolah atau tidak. Setelah itu kepala sekolah akan memilah dan memilih mana saja program yang sesuai. "92

Diperkuat dengan data dokumentasi program kerja sekolah yang sudah disahkan oleh Kepala Sekolah pada tanggal 07 Juli $2016 .{ }^{93}$

2. Strategi Implementasi Perencanaan Strategis Dalam Meningkatkan Mutu Pendidikan di SMK Al-Falah Moga Kabupaten Pemalang

Setelah terwujudnya perencanaan strategis SMK Al-Falah Moga, maka tidak kemudian berhenti disitu saja. Langkah selanjutnya adalah bagaimana mengimplementasikan perencanaan strategis tersebut.

\footnotetext{
${ }^{91}$ Wawancara Waka Kurikulum Bapak Abdul Ghofur, 22-11-2017

${ }^{92}$ Wawancara Waka kesiswaan Bapak Agus Pujianto, 11-01-2018

${ }^{93}$ Dokumentasi Program Kerja Sekolah SMK Al-Falah Moga Pemalang
} 
Implementasi perencanaan strategis di sini diartikan menerapkan program-program strategis yang ada pada rencana strategis dengan diwujudkan dalam bentuk Program Kerja Sekolah (PKS) dan Rencana Anggaran Pendapatan dan Belanja Sekolah (RAPBS). PKS dan RAPBS SMK Al-Falah ini dibuat tiap tahun, yaitu pada awal tahun ajaran dan mengacu atau berpedoman pada perencanaan strategis yang ada/sebelumnya.

Implementasi rencana strategis di SMK Al-Falah Moga menjadi tanggung jawab kepala sekolah secara umum. Secara khusus kepala sekolah memberikan tugas atau wewenang kepada bagian-bagian yang dapat melaksanakan program yang telah direncanakan sebagai koordinator, seperti wakil kepala sekolah sesuai bidangnya dan guru-guru yang terkait dengan program yang akan dilaksanakan. Selain itu, semua anggota sekolah memaksimalkan dalam menggunakan berbagai sumberdaya yang tersedia semaksimal mungkin, menggunakan pengalaman-pengalaman masa lalu yang dianggap efektif. Kepala Sekolah Bapak Rujito DW mengatakan bahwa:

"Saya memberikan kebebasan kepada semua anggota atau yang bersangkutan, tapi tetap dalam pengawasan saya karena semua itu tanggung jawab saya. Contoh saja dalam bidang sarana prasarana saya tugasi untuk menghendel seluruhnya terkait sarana". ${ }^{94}$

Beliau juga menjelaskan lebih lanjut:

"Sekolah swasta sebenarnya bebannya lebih berat, karena kita mandiri selain ada dana bos yang terbatas, kita harus mencari dana sendiri. Dari situ kami tetap menggunakan sumberdaya yang ada, 
tentang biaya kita anggarkan untuk setiap programnya sesuai dengan kemampuan sekolah tentunya". ${ }^{95}$

Dari paparan diatas dapat diketahui bahwa sekolah memanfaatkan semaksimal mungkin sumberdaya yang dimiliki dalam melaksanakan program strategis. Bapak Agus Pujianto selaku Waka Kesiswaan juga memberikan tanggapan serupa bahwa:

"Untuk mencapai mutu sekolah sangat terbuka, contohnya saja kepala sekolah memberikan wewenang kepada guru,terkait dengan pengembangan atau pembelajaran siswa. Contoh hal kecil saja, jika ada siswa yang melanggar beliau serahkan kepada kami. Tapi tetap saja semua masih dalam pengawasan bapak kepala sekolah. Contoh lain terkait dengan kegiatan siswa, siswa diberikan kebebasan untuk melakukan kegiatan apapun, bisa menggunakan fasilitas sekolah, asalkan izin terlebih dahulu.". ${ }^{96}$

Kebijakan atasan kepada bawahan memiliki efek yang sangat baik bilamana antar pimpinan dan bawahan saling percaya dan melaksanakan sesuai dengan tugas dan fungsinya.Peneliti melihat bahwa ungkapan tersebut sesuai dengan hasil observasi dan wawancara peneliti.

Hasil observasi menunjukkan bahwa di SMK Al-Falah ini mengaplikasikan sikap professional, seperti yang tertulis dalam visi sekolah dan seluruh komponen sekolah di SMK Al-Falah sudah berhasil menanamkan sikap-sikap lain seperti friendly, caring, dan integrity. Di bawah ini adalah salah satu cara sosialisasi sikap yang harus dimiliki semua komponen sekolah.

Tujuan disusunnya perencanaan strategis sekolah yakni untuk meningkatkan mutu pendidikan. Dalam meningkatkan mutu pendidikan

${ }^{95}$ Wawancara Kepala Sekolah Bapak Rjito Dw, 16-11-2017

${ }^{96}$ Wawancara Waka Kesiswaan Bapak Agus Pujianto, 11-01-2018 
sekolah, sekolah akan menentukan sasaran mutu pendidikan yang terdapat di perencanaan strategis, SMK Al-Falah Moga melibatkan 5 bidang, seperti:1) peningkatan manajemen sekolah, 2) pengembangan kurikulum, 3) pembinaan kesiswaan, 4) pengembangan fasilitas/sarana prasarana, 5) pengembangan ketenagaan/personalia. ${ }^{97}$ Seperti yang dikatakan oleh Kepala Sekolah BapakRujito Dw:

"Untuk peningkatan mutu sekolah, perencanaan strategis melibatkan 5 bidang yang mempunyai tujuan dan sasaran masingmasing, ada peningkatan manajemen sekolah, pengembangan kurikulum, pembinaan kesiswaan, pengembangan fasilitas/sarana prasarana, dan yang terakhir pengembangan ketenagaan/personalia. Dan masingmasing setiap akhir semester mengevaluasi bagaimana program yang sudah direncanakan dan pada awal semester akan melakukan pengembangan dari hasil evaluasi program tersebut". 98

Dalam dokumen program kerja sekolah, pencapaian mutu sekolah dalam bidang peningkatan manajemen sekolah yang tertulis di rencana strategis sekolah mencakup beberapa hal, antara lain: a) pembagian tugas dan fungsi guru dan tenaga kerja, b) menyusun program kerja tahunan, c) akreditasi jurusan tata busana dan budidaya tanaman, d) rapat rutin untuk pembinaan guru dan tenaga kepegawaian, e) monitoring kegiatan KBM, f) evaluasi secara berkala kegiatan KBM, g) menjalin kerja sama dengan DU/DI. ${ }^{99}$

Peneliti juga mewawancarai waka kurikulum SMK Al-Falah Moga Bapak Abdul Ghofar menyatakan bahwa:

"Dalam bidang pengembangan kurikulum, sasaran mutu yang tertulis di rencana strategis mencakup beberapa hal, antara lain: a)

\footnotetext{
${ }^{97}$ Dokumentasi Program Kerja Sekolah SMK Al-Falah Moga Pemalang

${ }^{98}$ Wawancara Kepala Sekolah Bapak Rujito Dw, 16-11-2017

${ }^{99}$ Dokumen Program Kerja Sekolah SMK Al-Falah Moga Pemalang
} 
penyusunan kurikulum KTSP Spektrum, b) rencana pembelajaran, c) penyusunan RPP bagi guru mapel, d) penjadwalan KBM, e) pelaksanaan ulangan bersama, tengah semester, dan akhir semester, f) analisis hasil evaluasi pelaksanaan KBM". 100

Diperkuat dengan data dokumentasi dari program kerja sekolah SMK Al-Falah Moga, bahwa kurikulum menentukan sasaran untuk meningkatkan mutu pendidikan, antara lain: a) penyusunan KTSP Spektrum, b) penyusunan RPP, c) ujian tengah semester, d) PSG/PKL, e) pengayaan kelas XII, f) ujian praktek, ujian nasional, ujian sekolah, g) pencetakan raport, h) persiapan akreditasi, i) pelaksanaan akreditasi, j) MGMP mata pelajaran. ${ }^{101}$

SMK Al-Falah juga merupakan sekolah kejuruan yang bercirikan Islam dan peduli terhadap lingkungan maka dengan mengarah pada visi danmisi, inilah yang ditekankan oleh sekolah untuk mencapai mutu pendidikan, hal ini dapat dipahami bahwa waka kesiswaan perlu menentukan sasaran, kebijakan, dan kegiatannya, seperti yang disampaikan oleh Waka Kesiswaan Bapak Agus Pujianto sebagai berikut:

"Untuk meningkatkan mutu pendidikan, salah satuyang berpengaruh yaitu bagaimana kondisi siswa, oleh sebab itu perlu adanya penerimaan calon siswa baru yang selektif dengan menerapkan sistem penyaringan antara penelusuran minat dan motivasi, potensi kecerdasan, akademik dan non akademik, dan terutama untuk di SMK Al-Falah adalah siswa yang memiliki minat untuk mendalami agama, berakhlak mulia, dan disiplin". 102

\footnotetext{
${ }^{100}$ Wawancara Waka Kurikulum Bapak Abdul Ghofar, 22-11-2017

${ }^{101}$ Dokumen Program Kerja Sekolah SMK Al-Falah Moga Pemalang

${ }^{102}$ Wawancara Waka Kesiswaan Bapak Agus Pujianto,11-01-2018
} 
Selain dengan menyeleksi siswa dan kurikulum untuk meningkatkan mutu pendidikan di SMK Al-Falah Moga yang paling berpengaruh adalah sumber daya manusia. Parapersonel sekolah harus bersikap profesional dalam bertugas dan mengembangkan dirinya. Berikut hasil wawancara dari waka humas dan SDM Bapak Gunawan Priyono:

"Sasaran pencapaian mutu bidang humas dan SDM sebagai berikut: 1) penambahan guru produktif dan normatif, 2) penambahan tenaga kependidikan, 3) pengiriman guru dalam kegiatan MGMP, 4) pengiriman diklat peningkatan kompetensi bagi guru dan tenaga kependidikan."103

Terkait dengan hal itu, sekolah mencoba menfasilitasi dan mendukung dengan sikap pedulisekolah yang selalu mengadakan program-program untuk meningkatkan kompetensi tenaga pendidikan dan siswa. Seperti paparan dari Bapak Kepala sekolah:

"Program untuk meningkatkan kualitas guru disini saya selalu mengikutkan guru-guru untuk diklat, workshop, dan seminar. Serta biasanya setelah saya ada workshop atau seminar yang saya ikuti, saya akan share kepada semua warga sekolah terutama guru-guru dan tenaga kependidikan yang lainnya." 104

Paparan data diatas dapat dipahami bahwa setiap pihak yang terlibat menyusun program dan strategi sesuai dengan bidangnya masingmasing dan untuk sasaran mutu pendidikan sekolah diharapkan dapat mengelola fasilitas, mulai dari pengadaan, pemeliharaan dan perbaikan, hingga pengembangan yang dapat menciptakan sekolah yang bersih, rapi,

\footnotetext{
${ }^{103}$ Wawancara Waka Humas Bapak Gunawan Priyono,, 12-01-2018

${ }^{104}$ Wawancara Kepala Sekolah Bapak Rujito Dw,16-11-2017
} 
indah sehinggadapat menciptakan kondisi yang menyenangkan baik guru maupun siswa untuk berada di sekolah dalam rangka menunjang proses pendidikan khususnya proses belajar mengajar.

Dan dari hasil wawancara diatas, peneliti menemukan temuan bahwa dalam melaksanakan program srategis di SMK Al-Falah dalam meningkatkan mutu pendidikan dengan: 1) melibatkan stakeholdersdengan memberikan kebebasan terhadap staff-staffnya, dan memberikan tugas sesuai dengan bidangnya; 2) memaksimalkan sumberdaya yang ada dengan menganggarkan biaya pelaksanaan program, dan menggunakan sarana dan prasarana yang ada.

3. Evaluasi Peningkatan Mutu Pendidikan dalam Perencanaan Strategis di SMK Al-Falah Moga

Perencanaan strategis dalam meningkatkan mutu pendidikan yang telah disetujui dan dilaksanakan, perlu adanya evaluasi. Evaluasi ini bertujuan untuk mengetahui program mana yang telah terlaksana, dan program mana yang terlaksana akan tetapi belum menimbulkan dampak positif terhadap mutu sekolah. Pelaksanaan evaluasi di SMK Al-Falah Moga, Kepala Sekolah mengikutsertakan setiap unsur yang terlibat dalam program, khususnya guru dan tenaga lainnya agar mereka dapat menjiwai setiap penilaian yang dilakukan dan memberikan alternatif pemecahan. Demikian pulaorang tua peserta didik dan masyarakat sebagai pihak eksternal harus dilibatkan untuk menilai keberhasilan program yang telah dilaksanakan. 
Berkaitan dengan evaluasi Kepala Sekolah secara berkala akan melakukan rapat koordinasi sebagai bentuk pengawasan terhadap kegiatan sekolah baik menyangkut kebijakan, penyelenggarakan kegiatan pendidikan termasuk pengelolaan biaya pendidikan. Pengawasan dan evaluasi pada hakekatnya juga merupakan bentuk pengendalian terhadap manajemen sekolah menuju efisiensi kegiatan sekolah sebagai upaya meningkatkan mutu pendidikan di SMK Al-Falah Moga.

Informasi yang diperoleh peniliti dalam wawancara, Kepala Sekolah Bapak Rujito Dw mengatakan:

"Evaluasi rencana pengembagan sekolah ini melibatkan seluruh stakeholders, seperti komite sebagai wadah perwakilan dari orang tua memiliki fungsi sebagai mitra sekolah dalam hal melakukan evaluasi dan pengawasan terhadap kebijakan program penyelenggaraan pendidikan di SMK Al-Falah, karena hampir 75\% siswa siswi SMK disini tinggal dipondok, jadi diwakili oleh komite, dan walimurid biasanya hanya diberikan pengumuman setelahnya terkait program sekolah". ${ }^{105}$

Untuk mendukung peryataan ini, maka wakil bidang kesiswaan menyatakan bahwa:

"Evaluasi program kerja di sekolah ini dilakukan satu tahun diakhir tahun, biasanya seperti itu, dan bisa saja tiba-tiba diadakan rapat terkait program sekolah, seperti rapat koordinasi". ${ }^{106}$

Wakil bidang humas pun menambahkan bahwa:

"untuk teguran dan masukan dari kepala sekolah ataupun dari sesama guru, disini juga ada, itu kita anggap evaluasi”. 107

Wakil bidang kurikulum menambahkan bahwa:

"untuk evaluasi program kerja kurikulum sendiri, lebih kepada penilaian hasil belajar siswa, evaluasi kegiatan belajar mengajar. "108

\footnotetext{
${ }^{105}$ Wawancara Kepala Sekolah Bapak Rujito Dw,16-11-2017

${ }^{106}$ Wawancara Waka Kesiswaan Bapak Agus Pujianto,22-11-2017

${ }^{107}$ Wawancara Waka Humas Bapak Gunawan Priyono, 22-11-2017
} 
Diperkuat dengan data dokumentasi kurikulum SMK Al-Falah Moga Pemalang, terkait dengan evaluasi kegiatan belajar mengajar, mekanisme penilaian dan jadwal penilaian. ${ }^{109}$

Dari penjelasan di atas dapat dipahami bahwa evaluasi sebagai upaya meminimalisisr persoalan yang dihadapi sekolah sebagai hambatan sekaligus mencari pemecahannya. Pengawasan dan evaluasi pada hakekatnya juga merupakan bentuk pengendalian terhadap manajemen sekolah menuju efisiensi kegiatan sekolah sebagai upaya meningkatkan mutu pendidikan di SMK Al-Falah Moga.

Evaluasi sangat penting dilakukan oleh sebuah organisasi atau lembaga, guna mengetahui seberapa besar kesusksesan yang diraih, untuk mengetahui apa yang menjadi kendala dan hambatan sehingga program tersebut tidak berjalan dengan rencana yang diharapkan. Begitu pulayang terjadi di SMK Al-Falah Moga,sebelum melaksanakan program atau segala sesuatu yang berkaitan dengan pendidikan atau lembaganya, selalu diadakan evaluasi, guna mencari feedback-nya.

Selanjutnya diadakan perbaikan yang terus menerus disertai dengan analisa dari berbagai unsur, khusunya para pengelola, berikut penuturan hasil wawancara peneliti dengan Kepala Sekolah, sebagai berikut:

"Melalui monitoring dan evaluasi, kita mendapatkan banyak feedback untuk perbaikan program kedepannya. Siklus ini dilakukan terus menerus". ${ }^{110}$

\footnotetext{
${ }^{108}$ Wawancara Waka Kurikulum Bapak Abdul Ghofar, 22-11-2017

${ }^{109}$ Dokumentasi Kurikulum SMK Al-Falah terlampir

${ }^{110}$ Wawancara Kepala Sekolah Bapak Rujito Dw, 16-11-2017
} 
Lebih lanjut lagi Bapak Rujito menuturkan bahwa evaluasi internal yang dilakukan di sekolah adalah lebih dikhususkan kepada:

"Proses pembelajaran di kelas, kepala sekolah sebagai penanggungjawab, melakukan monitoring sebulan sekali di tiap-tiap kelas, dan kadang kepala sekolah bersama-sama dengan guru senior yang memiliki kompeten di bidang mata pelajaran tertentu. Hal ini dilakukan untuk mengetahui apakah maksimal atau tidak dalam pelaksanaannya". 111

Salah satu pendekatan dalam membina guru SMK Al-Falah Moga yaitu melakukan supervisi, bentuk supervisi yang dilakukan oleh sekolah yakni pembinaan. Dapat dipahami dalam suatu wawancara dengan Bapak Gunaidi Priyono, selaku Waka Humas sebagai berikut:

"Supervisi yang dilakukan oleh kepala sekolah lebih pada pembinaan atau membimbing, jadi ketika ada kesalahan yang dilakukan oleh guru atau kurang tepat dalam menerapkan metode pembelajaran, maka kepala sekolah memanggil ke dalam ruangannya untuk diberikan arahan atau nasehat". ${ }^{112}$

Dari paparan diatas dapat dipahami bahwa Kepala Sekolah melakukan berbagai pendekatan dalam meningkatkan kualitas guru. Adapun upaya yang dilakukan adalah untuk meningkatkan mutu guru di SMK Al-Falah yaitu supervisi yang dilakukan oleh kepala sekolah bersifat bimbingan, sehingga guru merasa nyaman dan dihargai.Sedangkan monitoring dan evaluasi eksternal, lanjut Bapak Rujito Dw, bahwa:

"Evaluasi dan monitoring lebih pada pengawasan dan penilaian yang dilakukan oleh pihak-pihak tertentu diluar sekolah. Misalnya

${ }^{111}$ Wawancara Kepala Sekolah Bapak Rujito Dw, 16-11-2017

${ }^{112}$ Wawancara Waka Humas Bapak Gunawan Priyono, 22-16-2017 
dilakukan oleh Kandepag Kabupaten Pemalang, dan Dinas Pendidikan Kabupaten Pemalang". 113

Dari paparan data diatas dapat dipahami bahwa monitoring dan evaluasi di SMK, bertujuan bukan untuk menekan kreatifitas semua komponen warga sekolah tetapi diupayakan agar semua komponen warga sekolah dan warga masyarakat didorong untuk terlibat secara langsung dalam penyelaenggaraan pendidikan, khususnya evaluasi pendidikan yang diharapkan dapat meningkatkan mutu pendidikan. Hal ini perlu agar tercipta peningkatan rasa memiliki, dan peningkatan rasa memiliki ini akan meningkat pula dedikasi warga sekolah dan masyarakat terhadap pengembangan mutu SMK Al-Falah Moga.

\section{Temuan Penelitian}

Berdasarkan hasil penelitian dan berbagai wawancara yang telah dilakukan oleh peneliti dari semua sumber informasi perencanaan/penyusunan strategi, pelaksanaan rencana strategi dalam meningkatkan mutu, serta evaluasi dan monitoring, temuan yang dikemukakan pada bagian ini berdasarkan paparan data yang diperoleh di lapangan yang dirumuskan berdasarkan interpretasi data.

Penyajian temuan tersebut bertujuan untu menjawab permasalahan penelitian yang telah dikemukakan pada bab pendahuluan. Atas dasar fokuspenelitian dan paparan data yang telah disajikan sebelumnya, akhirnya dihasilkan temuan-temuan sebagai berikut:

\footnotetext{
${ }^{113}$ Wawancara Kepala Sekolah Bapak Rujito Dw, 16-11-2017
} 
1. Penyusunan perencanaan strategis dalam meningkatkan mutu pendidikan di SMK Al-Falah Moga Pemalang.

Penyusunan perencanaan strategis di SMK Al-Falah Moga Pemalang dengan melalui langkah-langkah sebagai berikut:

a. Merumuskan visi, misi dan tujuan sekolah

b. Membentuk satgas penyusunan perencanaan strategis

c. Proses perumusan

d. Penetapan perencanaan strategis

2. Strategi implementasi perencanaan strategis untuk meningkatkan mutu pendidikan di SMK Al-Falah Moga Pemalang.

Strategi implementasi perencanaan strategis di SMK Al-Falah dalam meningkatkan mutu pendidikan dengan:

a. Melibatkan stakeholders dengan memberikan wewenang dalam mengelola program yang akan dilaksanakan kepada staff-staff, dan memberikan tugas sesuai dengan bidangnya.

b. Memaksimalkan sumberdaya yang ada dengan menganggarkan biaya pelaksanaan program, dan menggunakan sarana dan prasarana yang ada.

3. Evaluasi perencanaan strategis terhadap mutu pendidikan di SMK AlFalah Moga Pemalang.

Teknik evaluasi perencanaan strategis yang dilakukan dalam peningkatan mutu pendidikan SMK Al-Falah Moga Pemalang yaitu dengan evaluasi internal dan eksternal yang dilakukan setiap semester 
dan akhir tahun serta melibatkan stakeholders serta akreditasi yang dilakukan oleh badan akreditasi nasional sekolah (BAN-S) Evaluasi program dilakukan secara sistematis pada akhir tahun ajaran dan akhir semester, yang secara keseluruhan evaluasi program menggunakan model CIPP (context, input, process, dan product). 
Table 4 Hasil Temuan Penelitian SMK Al-Falah Moga Pemalang

\begin{tabular}{|c|c|c|c|}
\hline No & Fokus & Proses & Temuan \\
\hline \multirow[t]{4}{*}{1} & \multirow{4}{*}{$\begin{array}{l}\text { Langkah-langkah } \\
\text { penyusunan } \\
\text { perencanaan strategis } \\
\text { dalam meningkatkan } \\
\text { mutu pendidikan } \\
\text { SMK Al-Falah Moga } \\
\text { Pemalang }\end{array}$} & $\begin{array}{l}\text { Merumuskan visi, misi, dan } \\
\text { tujuan sekolah }\end{array}$ & $\begin{array}{l}\text { 1) Visi, misi, dan tujuan SMK Al- } \\
\text { Falah Moga Pemalang } \\
\text { ditentukan dan ditetapkan } \\
\text { dalam rapat koordinasi } \\
\text { 2) Melibatkan yayasan, kepala } \\
\text { sekolah, dewan guru, komite } \\
\text { 3) Disusun dengan memperhatikan } \\
\text { kebutuhan dan harapan } \\
\text { stakeholders } \\
\text { 4) Sosialisasi dan internalisasi visi, } \\
\text { isi, dan tujuan dengan berbagai } \\
\text { cara. Seperti pemasangan papan } \\
\text { di tempat strategis }\end{array}$ \\
\hline & & $\begin{array}{l}\text { Membentuk satgas } \\
\text { penyusun rencana strategis }\end{array}$ & $\begin{array}{l}\text { 1) membentuk tim berjumlah } 9 \\
\text { orang, terdiri dari waka dan } \\
\text { kaprog } \\
\text { 2) Tim menggali masukan dan } \\
\text { aspirasi dari masing-masing } \\
\text { bagian sesuai dengan tugasnya }\end{array}$ \\
\hline & & Proses perumusan & $\begin{array}{l}\text { 1) mengkaji program-program } \\
\text { yang diusulkan } \\
\text { memilah dan memilih program } \\
\text { yang sesuai visi, misi dan } \\
\text { tujuan sekolah }\end{array}$ \\
\hline & & $\begin{array}{c}\text { Penetapan perencanaan } \\
\text { strategis }\end{array}$ & $\begin{array}{l}\text { 1) rumusan perencanaan strategis } \\
\text { dikaji ulang oleh kepala sekolah } \\
\text { 2) Kepala sekolah mengesahkan } \\
\text { 3) Sosialisasi program renstra }\end{array}$ \\
\hline \multirow[t]{2}{*}{2} & \multirow{2}{*}{$\begin{array}{c}\text { Strategi } \\
\text { implementasi } \\
\text { perencanaan strategi } \\
\text { di SMK Al-Falah } \\
\text { Moga Pemalang } \\
\text { dalam meningkatkan } \\
\text { mutu pendidikan }\end{array}$} & Melibatkan stakeholders & $\begin{array}{l}\text { 1) Pimpinan memberikan } \\
\text { wewenang untuk mengolah } \\
\text { progam yang akan dilaksanakan } \\
\text { kepada staff-staff } \\
\text { 2) Memberikan tugas sesuai } \\
\text { dengan bidangnya }\end{array}$ \\
\hline & & $\begin{array}{c}\text { Memaksimalkan } \\
\text { sumberdaya yang ada }\end{array}$ & $\begin{array}{l}\text { Menganggarkan } \\
\text { pelaksanaan program } \\
\text { 2) } \\
\text { Menggunakan sarana dan } \\
\text { prasarana yang ada }\end{array}$ \\
\hline
\end{tabular}




\begin{tabular}{|c|c|c|c|}
\hline 3 & $\begin{array}{c}\text { Evaluasi } \\
\text { perencanaan strategis } \\
\text { terhadap mutu } \\
\text { pendidikan di SMK } \\
\text { Al-Falah Moga } \\
\text { Pemalang }\end{array}$ & $\begin{array}{l}\text { Evaluasi internal dan } \\
\text { eksternal dengan model } \\
\text { CIPP }\end{array}$ & $\begin{array}{l}\text { 1) Internal, mengevaluasi seluruh } \\
\text { program yang dilakukan oleh } \\
\text { kepala sekolah. } \\
\text { 2) Eksternal, monitoring yang } \\
\text { dilakukan oleh pengawas } \\
\text { pendidikan serta akreditasi dari } \\
\text { BAN S/M. } \\
\text { 3) Evaluasi program dilakukan } \\
\text { menggunakan model CIPP } \\
\text { (context, input, process, dan } \\
\text { product) }\end{array}$ \\
\hline
\end{tabular}




\section{BAB V}

\section{PEMBAHASAN HASIL PENELITIAN}

Pada bab ini peneliti akan menyajikan sejumlah temuan dilapangan yang dipaparkan melalui pembahasan singkat. Pembahasan ini bertujuan untuk mensignifikasikan fokus-fokus penelitian dengan temuan-temuan yang diperoleh berdasarkan sejumlah teori yang ada, sehingga dapat diperoleh temuan teori subtantif. Adapun fokus yang akan dibahas adalah sebagai berikut:

\section{A. Proses Penyusunan Perencanaan Strategis Dalam Meningkatkan Mutu}

\section{Pendidikan SMK Al-Falah Moga Pemalang}

Proses perencanaan strategis sperti yang dimaksud dalam penelitian ini diartikan sebagai langkah-langkah atau cara-cara yang ditempuh sekolah dalam menyusun perencanaan strategis di sekolah. Di SMK Al-Falah Moga Pemalang berdasarkan hasil temuan penelitian, cara atau langkah-langkah yang ditempuh dalam menyusun perencanaan strategis adalah dengan melalui beberapa tahap, yaitu: pertama, tahap perumusan visi, misi dan tujuan sekolah; kedua, tahap pembentukan satgas penyusun perencanaan strategis; ketiga, proses perumusan; dan keempat, penetapan perencanaan strategis tersebut.

Sebagaimana disebutkan oleh Djunaedi bahwa perencanaan strategis tidak mengenal standar baku, dan prosesnya mempunyai variasi yang tidak terbatas. Tiap penerapan perlu merancang variasinya sendiri sesuai kebutuhan, situasi dan kondisi setempat. Meskipun demikian, dikatakannya secara umum proses perencanaan strategis memuat unsur-unsur:(1) 
perumusan visi dan misi, (2) pengkajian lingkungan eksternal, (3) pengkajian lingkungan internal, (4) perumusan isu-isu strategis, dan (5) penyusunan strategi pengembangan (yang dapat ditambah dengan tujuan dan sasaran). Proses perencanaan strategis tidak bersifat sekuensial penuh, tapi dapat dimulai dari salah satu dari langkah ke (1), (2), atau (3). Ketiga langkah tersebut saling mengisi.Setelah ketiga langkah pertama ini selesai, barulah dilakukan langkah ke (4), yang disusul dengan langkah ke (5).Setelah rencana strategis (renstra) selesai disusun, maka diimplementasikan dengan terlebih dahulu menyusun rencana-rencana kerja (aksi/tindakan). ${ }^{114}$

Sebagaimana juga dikatakan Umar, untuk membahas suatu perencanaan strategis hendaknya kita mengacu pada model Manajemen strategis agar pembahasannya terfokus. Ketika ia melihat tiga modelmodeldari Wheelen-Hunger, model dari Fred R. David, dan model dari Glenn Baseman-Arvin Platak--, dijelaskannya bahwa ada beberapa elemen utama dari manajemen strategis, yaitu: pertama, visi, misi, dan falsafah (kredo/nilainilai); kedua, analisis lingkungan eksternal dan internal; ketiga, analisis pilihan strategis; keempat, sasaran jangka panjang; kelima, strategi fungsional; keenam, program, pelaksanaan, pengendalian, dan evaluasi. ${ }^{115}$

Di SMK Al-Falah Moga Pemalang setidaknya sudah memenuhi beberapa unsur utama yang ada dengan proses pertama merumuskan visi,

\footnotetext{
${ }^{114}$ Achmad Djunaedi, “Keragaman Pilihan Corak Perencanaan (Planning Styles) untuk Mendukung Kebijakan Otonomi Daerah", Makalah dipresentasikan dalam Seminar \& Temu Alumni MPKD 2000, di Werdhapura,Sanur, Bali, 27-30 Agustus 2000.hlm. 4

${ }^{115}$ Husein Umar, Strategic Managemen in Action, Konsep, Teori, dan Teknik Mneganalisis manajemen Strategis Strategic Business Unit Berdasarkan Konsep Michael R. Porter, Fred R. David, dan Wheelen-Hunger (Jakarta: Gramedia Pustaka Utama, 2001), hlm. 19-27
} 
misi dan tujuan sekolah oleh stakeholders, kemudian langkah kedua dengan melakukan analisis lingkungan strategis diikuti langkah ketiga merumuskan isu-isu strategis menjadi program-program strategis oleh satgas penyusun renstra, langkah keempat menyusun rencana program operasional berupa program kerja sekolah dan rencana anggaran pendapatan dan belanja sekolah.

Dalam merumuskan visi, misi dan tujuan SMK Al-Falah Moga Pemalang adalah dengan melibatkan seluruh komponen yang ada di sekolah tersebut, meliputi dewan guru, dewan komite, staff.Hal ini menunjukkan bahwa kepala sekolah sebagai pimpinan sekaligus manajer di sekolah tersebut telah memahami arti penting dari partisipasi dalam perencanaan strategis, dalam hal ini pada penyusunan visi, misi dan tujuan organisasi.

Sebagaimana dikatakan oleh Juran dalam Gasperz, perencanaan mutu (quality planning) seharusnya melibatkan partisipasi mereka yang akan dipengaruhi oleh rencana. Juga mereka yang merencanakan kualitas seharusnya dilatih dalam menggunakan metode-metode modern dan alat-alat perencanaan kualitas. ${ }^{116}$

Sebagaimana dikemukakan juga oleh Sagala mengutip Broocover (1982), proses merancang suatu perencanaan harus memberikan kesempatan yang cukup untuk berdiskusi "brainstorming", mengutarakan perasaan dan sikap, mengidentifikasi kebutuhan dan harapan, menyiapkan informasi, dan memecahkan selisih pendapat. Kegiatan tersebut penting artinya untuk mendapatkan masukan yang berharga selama proses perencanaan

${ }^{116}$ Vincent Gasperz,Total Quality Management (Jakarta: Gramedia Pustaka Utama, 2001), hlm.7-8 
berlangsung. Keefektifan perencanaan sekolah menghasilkan programprogram yang luwes dan berpusat pada keberhasilan belajar peserta didik, yang mencakup programpelajaran, pengajaran, pengembangan kurikuler, bahan pengajaran, kegiatan siswa, keuangan, gedung sekolah, dan hubungan masyarakat. Dengan demikian proses perencanaan yang efektif adalah kepala sekolah melibatkan guru untuk bekerja sama dalam upaya mengefektifkan program sekolah, dan memprakarsai program perubahan melalui usaha kolektif bersama guru dengan garis besar tujuan yang telah ditentukan. ${ }^{117}$

Tujuan rencana sekolah adalah membantu sekolah menjelaskan pengelolaan sekolah sekarang dan masa mendatang.Mendorong dan mendukung partisipasi masyarakat. Mendorong adanya keputusan-keputusan tingkat sekolah, dan mendorong terciptanya ketentuan dalam perencanaan dan pelaksanaannya.Upaya mendorong ini sebagai bagian dari demokrasi pendidikan yang sudah menjadi tekad seluruh lapisan masyarakat dalam berbangsa dan bernegara.

Visi, misi dan tujuan SMK Al-Falah Moga Pemalang yang dirumuskan secara terbuka dan memberikan kesempatan bagi stakeholders untuk memberikan usulan dan masukan secara bebas juga merupakan hal penting dalam proses penyatuan arah organisasi/sekolah. Dengan proses yang demikian secara otomatis visi, misi dan tujuan sekolah merupakan hasil rumusan bersama, milik bersama, untuk diusahakan dan diraih bersama.

${ }^{117}$ Syaiful Sagala, Manajemen Strategik Dalam Peningkatan Mutu Pendidikan (Bandung: Alfabeta, 2007), hlm. 58. 
Apabila visi sekolah belummenjadi acuan bersama, maka sekolah akan kesulitan atau lambat dalam perkembangannya.

Sebagaimana dikatakan Sugeng bahwa kepala sekolah dengan kemampuan kepemimpinannya harus menyamakan visi setiap komponen sekolah. Sekolah yang tidak memiliki visi atau memiliki visi yang belum menjadi acuan kerja, maka setiap komponen sekolah tersebut akan bergerak ke arah yang menjadi visinya sendiri-sendiri, sehingga sekolah tersebut tidak punya arah karena setiap komponen menentukan arahnya sendiri. Visi harus dikembangkan dengan memperhatikan kebutuhan dan harapan stakeholderspotensial dan kegiatan utama lembaga. Visi dirumuskan dalam kalimat yang mudah dipahami dan menunjukkan suatu keadaan sekolah dalam jangka panjang (bisa berkisar 5-10 tahun).

Ditegaskan Sugeng bahwa kepala sekolah dengan kemampuan kepemimpinannya harus menyamakan visi setiap komponen tersebut. Proses menyamakan visi bukanlah hal yang mudah dan dapat dilakukan secara serta merta, namun membutuhkan proses yang bertahap. Jika hampir seluruh komponen sekolah sudah mulai memiliki kesamaan visi maka lembaga mulai memasuki tahap berkembang sampai akhirnya seluruh komponen menuju arah yang sama. Pada kondisi inilah sekolah sudah memiliki daya saing yang baik, atau mungkin sudah memiliki daya saing unggul.

Usaha kepala SMK Al-Falah Moga Pemalang agar visi, misi dan tujuan sekolah dapat dipahami dan dilaksanakan oleh seluruh komponen sekolah, dilakukan sosialisasi sekaligus internalisasi visi, misi dan tujuan 
sekolah dengan berbagai cara, diantaranya dibacakan pada saat upacara, kemudian dipasang di tempat-tempat strategis, hampir di semua ruang terdapat visi, misi dan tujuan sekolah. Selain itu, di depan pintu masuk ditulis pada papan yang besar semacam baliho agar semua orang yang masuk SMK ini bisa membacanya dengan mudah. Hal ini menunjukkan bahwa tahapan yang sedang terjadi pada SMK Al-Falah Moga Pemalang berkaitan dengan menyamakan visi termasuk pada tahap lembaga berkembang.

Kebijakan kepala sekolah membentuk satgas penyusun renstra merupakan langkah yang bijaksana.Tim yang terdiri dari semua wakil kepala sekolah dan ketua program studi setidaknya sudah mencakup semua komponen atau bidang garap dari keseluruhan manajemen di SMK Al-Falah Moga Pemalang. Lebih dari itu dalam temuan penelitian disebutkan bahwa tim atau satgas ini melakukan proses turun kebawah sesuai dengan bagiannya masing-masing untuk menjaring masukan dan aspirasi. Hal ini melahirkan metode yang cukup menarik bagi peneliti. Jadi tim ini oleh kepala sekolah diberi wewenang penuh dalam proses perumusan, bisa dikatakan sebagai tim formatur, namun tidak boleh meninggalkan prinsip demokrasi yaitu dengan mengedepankan aspirasi dari bawah.

Menurut pengalaman banyak kasus, setiap upaya perencanaan strategis umumnya selalu melibatkan sebuah tim perencana strategis. Sebuah tim diperlukan karena beberapa alasan. Sebuah tim perencanaan strategis yang berfokus organisasi perlu mempunyai dampak lintas organisasi. Tim tersebut akan dapat menghimpun informasi yang diperlukan dan solusi yang 
diusulkan, secara organisatoris, lebih mempunyai legitimasi(Galbraith, 1977). Juga, sebuah tim diperlukan hanya karena pekerjaan perencanaan tersebut diinginkan untuk selesai secepat mungkin. Demikian juga alasannya dalam perencanaan strategis yang berfokus pada komunitas, maka sebuah tim (yang terdiri dari satu satgas/komisi atau lebih) diperlukan dan melibatkan juga partisipasi masyarakat secara luas dan mungkin juga dengan mengundang konsultan.

B. Strategi Implementasi Perencanaan Strategis Dalam Meningkatkan Mutu Pendidikan SMK Al-Falah Moga Pemalang

J. David Hunger dan Thomas L. Wheelen, menyebutkan bahwa implementasi strategi adalah proses dimana manajemen mewujudkan strategi dan kebijakannya dalam tindakan melalui pengembangan program, anggaran dan prosedur. $^{118}$

Sondang P. Siagian berpendapat bahwa dalam implementasi suatu strategi, diperlukan keberadaan para menejer bawahan yang tepat pada kedudukan manajerial yang tepat pula. ${ }^{119}$

Definisi tersebut menunjukan pentingnya kebersamaan atau jalinan kerjasama antara atasan dan bawahan bahkan semua anggota organisasi dalam melaksanakan suatu program guna tercapainya tujuan yang telah ditentukan.

Hasil temuan di SMK Al-Falah Moga dalam implementasi perencanaan strategis yaitu sekolah melibatkan beberapa pihak. Hal ini

\footnotetext{
${ }^{118}$ J. David Hunger dan Thomas 1. Wheelen, Manajemen Strategis..., hlm. 17
}

${ }^{119}$ Sondang P. Siagian, Manajemen Strategik (Jakarta: PT. Bumi Aksara, 2005) hlm. 242. 
dilakukan oleh kepala sekolah dengan memberikan kebijakan atau tugas kepada penanggung jawab program sesuai dengan keahlian dibidangnya. Selain itu, lembaga dalam implementasi program meamaksimalkan sumberdaya yang ada dengan mencakup anggaran biaya pelaksanaan program. Dalam penganggaran ini, sekolah merasakan bahwa pembiayaan merupakan sebuah hambatan karena sekolah ini berstatus swasta yang dalam pembiayaannya mandiri.

Dengan keterlibatan berbagai pihak, diharapkan semua stakeholders selain terlibat dalam memberikan gagasan dalam perumusan juga mampu mendampingi proses implementasi program strategis tersebut sehingga menghasilkan atau berdampak positif terhadap mutu pendidikan. Selain itu, dalam proses implementasi penting untuk selalu dilakukan monitoring sebagai evalusi. Hal ini diungkapkan oleh Rohiat bahwa untuk menghindari berbagai penyimpangan, kepala sekolah perlu melakukan supervisi dan monitoring terhadap kegiatan-kegiatan peningkatan mutu yang dilakukan oleh sekolah. ${ }^{120}$

C. Evaluasi Rencana Strategis Dalam Meningkatkan Mutu Pendidikan SMK Al-Falah Moga Pemalang

Evaluasi program adalah suatu rangkaian kegiatan yang dilakukan dengan sengaja untuk melihat tingkat keberhasilan program. $^{121}$ Dalam evaluasi ini yang menjadi terget evaluasi adalah kegiatan dari implementasi

\footnotetext{
${ }^{120}$ Rohiat, Manajemen Sekolah; Teori Dasar dan Praktik Dilengkapi Dengan Contoh Rencana Strategis dan Rencana Operasional (Bandung: Refika Aditama, 2009), hlm. 76

${ }^{121}$ Suharsimi Arikunto, Dasar-Dasar Evaluasi Pendidikan Edisi Revisi (Jakarta: Bumi Aksara, 2005), hlm. 290.
} 
program strategis apakah sudah tercapai atau belum. Ralph Tyler berpendapat bahwa evaluasi pendidikan ialah proses yang menentukan sampai sejauh mana tujuan pendidikan dapat dicapai. ${ }^{122}$

Dari uraian diatas dapat diambil kesimpulan bahwa evaluasi program pada dasarnya ialah proses mengumpulkan data atau informasi terkait sejauh mana tingkat ketercapaian dari suatu kegiatan dilaksanakan. Kemudian data tersebut digunakan sebagai bahan pertimbangan pengambilan kebijakan atau keputusan dalam perencanaan, serta sebagai pengontrol penerapan program.

Evaluasi yang dilakukan oleh SMK Al-Falah Moga, tidak untuk mengetahui akhir kegiatan semata, akan tetapi sebagai bahan pertimbangan dalam memperbaiki program kedepannya. Evaluasi program peningkatan mutu dari sekolah ini mirip dengan model CIPP. CIPP merupakanmodelpenilaianprogram yang dikembangkan oleh Daniel L. Stufflebeam, model ini terdiri dari: ${ }^{123}$

1. Context Evaluation(penilaian konteks evaluasi) yang meliputi analisis masalah yang berhubungan dengan lingkungan pendidikan yang khusus. Secara singkat dapat dikatakan bahwa penilaian konteks adalah penilaian terhadap kebutuhan, tujuan pemenuhan kebutuhan, karakter individu.

2. Input Evaluation(penilaian tentang masukan) meliputi pertimbangan tentang sumber dan strategi yang diperlukan untuk mencapai tujuan umum dan khusus suatu program.

${ }^{122}$ Farida Yusuf, Evaluasi Program (Jakarta: Rineka Cipta, 2003), hlm. 3.

${ }^{123}$ Farida Yusuf , Evaluasi Program ( Jakarta: Rineka Cipta, 2003), hlm. 14. 
3. Process Evaluation(penilaian tentang proses) meliputi koleksi data penilaian yang telah ditentukan (dirancang) dan ditetapkan dalam praktik.

4. Product Evaluation(penilaian tentang product/hasil) penilaian evaluasi yang dilaksanakan oleh penilai dalam mengukur keberhasilan pencapaian tujuan yang diterapkan.

SMK Al-Falah Moga melakukan evaluasi dengan model tersebut:

1. Context Evaluation (penilaian konteks evaluasi)

SMK Al-Falah Moga Pemalang terus melakukan pengawasan dan monitoring terhadap program yang direncanakan, itu dilakukan untuk mengetahui potensi yang dimiliki sekolah dan program sesuai dengan harapan stakeholders. Serta dengan melakukan evaluasi sekolah akan mengetahui apa saja kegiatan yang mampu meningkatkan mutu pendidikan itu akan di pakai lagi untuk program tahun depannya lagi.

2. Input Evaluation (penilaian tentang masukan)

SMK Al-Falah Moga dalam mengavaluasi program peningkatan mutu pendidikan dengan melihat potensi yang dimilikinya, dengan harapan antara program yang direncanakan dapat sesuai dengan kondisi sekolah. Dalam hal ini sekolah mencari informasi dari beberapa pengguna sekolah, seperti dewan guru, staff, dewan yayasan dan komite dengan menyelenggarakan musyawarah.

3. Process Evaluation (penilaian tentang proses)

Penilaian ini dengan menggali informasi dan mengumpulkan data terkait dengan faktor-faktor pendukung dan penghambat terealisasinya program 
strategi. Yang selanjutnya dapat dijadikan bahan pertimbangan dalam menjalankan program di periode berikutnya.

\section{Product Evaluation (penilaian tentang produk/hasil)}

Penilain ini dikhususkan terhadap hasil akhir dari program yang dilaksanakan, seperti keberhasilan prestasi yang diraih danlulusan yang dapat diterima di perguruan tinggi.

Dari uraian diatas dapat diambil sebuah kesimpulan bahwa SMK AlFalah Moga merancang program dengan mempertimbangkan sesuai kebutuhan stakeholders. Evaluasi program yang dilakukan ialah dengan evaluasi internal dan eksternal. Evaluasi internal terkait dengan programprogram yang dilakukan oleh kepala sekolah. Sedangkan evaluasi eksternal dilakukan oleh pengawas pendidikan dari kementrian pendidikan dan budaya serta akreditasi yang dilakukan oleh Badan Akreditasi Nasional Sekolah/Madrasah.

Setalah melakukan perencanaan, penerapan dan evaluasi perencanaan strategis di sekolah, tentunya memiliki dampak terkait dengan mutu pendidikan. Mutu adalah sebuah hal yang dapat mengagambarkan tentang sesuatu. Peter dan Austin dalam Zazin mengungkapkan bahwa mutu adalah sebuah hal yang berhubungan dengan gairah dan harga diri. ${ }^{124}$

Dari urain tersebut menunjukkan bahwa mutu adalah sifat yang melekat pada sesuatu benda yang menunjukkan kualitas. Lembaga pendidikan

${ }^{124}$ Nur Zazin, Gerakan Menata Mutu Pendidikan; Teori \& Aplikasi (Jakarta: Ar-Ruzz Media, 2011), hlm. 54 
seperti sekolah juga pasti memiliki kriteria apakah sekolah tersebut bermutu atau tidak.

Ridwan Abdullah Sani, dkk. menyebutkan standar sekolah yang bermutu dapat dilihat dari dua sudut yaitu:

Pertama, ukuran sekolah yang bermutu dari kacamata pengguna/penerima manfaat, pada umumnya ialah:

1. Sekolah memiliki nilai akreditasi A

2. Lulusan dapat diterima oleh jenjang pendidikan diatasnya yang merupakan sekolah terbaik

3. Memiliki guru yang profesional, ditunjukkan dengan hasil uji kompetensi guru (UKG) dan kinerja yang baik

4. Hasil Ujian Nasional (UN) baik

5. Peserta didik memiliki prestasi dalam berbagai kompetisi baik akademik maupun non akademik, dan

6. Peserta didik memiliki karakter yang baik.

Kedua, sekolah bermutu menurut kacamata pemerintah: yaitu sekolah yang memenuhi Standar Nasional Pendidikan (SNP). Menurut Peraturan Pemerintah Republik Indonesia nomor 19 tahun 2005 tentang Standar Nasional Pendidikan pasal 1 ayat (1) memberikan pengertian bahwa, Standar Nasional Pendidikan (SNP) adalah kriteria minimal tentang sistem pendidikan diseluruh wilayah hukum negara kesatuan republik indonesia. Standar Nasional Pendidikan tersebut meliputi:

1. Lulusan yang cerdas komprehensif. Kualifikasi kemampuan lulusan yang mencakup sikap, pengetahuan dan ketrampilan.

2. Kurikulum yang dinamis sesuai kebutuhan zaman. Ruang lingkup materi dan kompetensi yang dituangkan dalam kriteria tentang kompetensi tamatan, kompetensi bahan kajian, kompetensi mata pelajaran, dan 
silabus pembelajaran yang harus dipahami oleh peserta didik pada jenjang dan jenis pendidikan tertentu.

3. Proses pembelajaran yang berorientasi pada siswa dan mengembangkan kreativitas siswa.

4. Proses pembelajaran yang dilengkapi dengan sistem penilaian dan evaluasi pendidikan yang andal, sahih, dan memenuhi prinsip-prinsip penilaian.

5. Guru dan tenaga kependidikan yang profesional, berpengalaman, dan dapat menjadi teladan

6. Sarana dan prasarana yang digunakan lengkap dan sesuai dengan kearifan lokal.

7. Sistem manajemen yang akurat dan andal.

8. Pembiayaan pendidikan yang efektif dan efisien.

Hasil temuan yang diperoleh dari SMK Al-Falah Moga Pemalang, sekolah ini memiliki kriteria yang hampir sama dengan standar sekolah yang bermutu menurut Ridwan Abdullah Sani, dkk. sekolah ini mengalami peningkatan jumlah peserta didik, peningkatan nilai hasil UN, lulusan dapat diterima di perguruang tinggi, diterima di perusahaan-perusahaan., mengalami peningkatan prestasi akademik maupun non akademik, terpenuhinya sarana penunjang proses pembelajaran, serta sekolah ini memiliki akreditasi "A". 


\section{BAB VI \\ PENUTUP}

\section{A. Kesimpulan}

Berdasarkan rumusan masalah dan hasil pembahasan mengenai implementasi perencanaan strategis dalam meningkatkan mutu pendidikan di SMK Al-Falah Moga Kabupaten Pemalang, maka penulis menyimpulkan beberapa hal sebagai berikut:

1. Proses penyusunan perencanaan strategis dalam meningkatkan mutu pendidikan di SMK Al-Falah Moga Pemalang menerapkan beberapa langkah yaitu; pertama, merumuskan visi, misi, dan tujuan sekolah; kedua, membentuk satgas penyusun perencanaan strategis; ketiga, proses perumusan; dan keempat, penetapan perencanaan strategis tersebut.

2. Strategi implementasi perencanaan strategis dalam meningkatkan mutu pendidikan di SMK Al-Falah Moga Kabupaten Pemalang, yaitu: a) melibatkan stakeholders dengan memberikan wewenang terhadap staffstaff, melakukan pengumuman program diawal tahun, mengadakan rapat koordinasi setiap bulan, dan memberikan tugas sesuai dengan bidangnya. dan b) memaksimalkan sumberdaya yang dimiliki dengan menganggarkan biaya implementasi program, memberikan pelatihan kepada guru, dan menggunakan sarana dan prasarana yang ada.

3. Evaluasi perencanaan strategis terhadap mutu pendidikan di SMK AlFalah Moga Kabupaten Pemalang, yaitu evaluasi internal dan eksternal. Internal dilakukan oleh kepala sekolah, sedangkan eksternal adalah 
monitoring yang dilakukan oleh pengawas pendidikan serta akreditasi dari Badan Akreditasi Nasional Sekolah/Madrasah. Evaluasi program dilakukan secara sistematis pada akhir tahun ajaran dan akhir semester, yang secara keseluruhan evaluasi program menggunakan model CIPP (context, input, process, dan product);

\section{B. Saran}

Berdasarkan hasil temuan penelitian, maka disampaikan saran terhadap penelitian lanjut sebagai berikut:

1. Penelitian ini hanya dilaksanakan pada satu lokasi, yaitu SMK Al-Falah Moga Pemalang dengan pendekatan studi kasus. Untuk eningkatkan kualitas penelitian tetang impleentasi perencanaan strategis di sekolah, maka perlu dilakukan penelitian lanjutan dengan melibatkan objek yang berbeda dan lebih luas jangkauannya serta bersifat multi kasus maupun multi situs.

2. Dalam rangka memperluas wacana keilmuan, khususnya mengenai implementasi perencanaan strategis di sekolah, maka perlu diadakan penelitian secara lebih mendalam, dengan fokus penelitian yang lebih tajam karena banyaknya dimensi perencanaan strategis yang belum tersentuh. 


\section{DAFTAR PUSTAKA}

Arikunto, Suharsimi. 2006. Prosedur Penelitian: Suatu Pendekatan Praktek Edisi Revisi IV. Jakarta: PT. Rineka Cipta.

Bogdan, Robert S \& Sari Knope Biklan. 1982. Qualitative Research for Education an Introduction to Theory and Methods. Boston: Allynan Bacon.

Bryson, John M. 2001. Perencanaan Strategis bagi Organisasi Sosial. Yogyakarta: Pustaka Pelajar.

David, Fred R.. 2006. Manajemen Strategis, Edisi Sepuluh. Jakarta: Salemba Empat.

Danim, Sudarwan. 2006. Visi Baru Manajemen Sekolah. Jakarta: Bumi Aksara.

Departemen Pendidikan Nasional. 2002. Manajemen Peningkatan Mutu Berbasis Sekolah. Jakarta: Direktorat Jenderal Pendidikan Dasar dan Menengah Direktorat Sekolah Lanjutan Tingkat Pertama.

Depdikbud. 1994. Pengembangan Sekolah Unggul. Jakarta: Dirjen Disdasmen.

Depdiknas. 2002. Manajemen Peningkatan Mutu Berbasis Madrasah: Konsep Dasar. Jakarta: Ditjen Dikdanmen.

Gasperz. 2002. Jurnal "Penerapan Total Management in Education (TQME) pada Pergruan Tinggi di Indonesia”. Jjilid 6.

Glueck, William F. dan Lawrence R. Jauch. 1994. Manajemen Strategis dan Kebijakan Perusahaan. Jakarta: Penerbit Erlangga.

Hadi, Sutrisno. 1994. Metodologi Research II. Yogyakarta : Andi Offset.

HB, Sutopo. 1996. Metode Penelitian Kualitatif, Metode Penelitian Untuk Ilmu-ilmu Sosial dan Budaya. Surakarta: UNS.

Hunger, J. David \& Thomas L. Wheelen. 2012. Manajemen Strategis. Yogyakarta: Penerbit Andi.

James A.F. Stoner et.all. 1996. Manajemen. Jakarta: Buana Ilmu Populer. 
Junaedi, Achmad. 2000. "Keragaman Pilihan Corak Perencanaan (Planning Styles) untuk Mendukung Kebijakan Otonomi Daerah”, dalam Seminar \& Temu Alumni MPKD 2000.

Kartini Kartono. 1990. Pengantar Metodologi Research Sosial. Bandung : CV. Mandar Maju.

Lukas. 1992. Masalah Wawancara dengan Informan Pelaku Sejarah di Jawa. Aspek Manusia dalam Penelitian Masyarakat. Jakarta: Gramedia.

Michael R. Porter, Fred R. David, dan Wheelen-Hunger. Jakarta: Gramedia Pustaka Utama.

Miles, Mattew B. dan A. Michele Haberman. 1992. An Expanded Sourcebook Qualitative Data Analysis, Second Edition, terj. Tjetjep R. Rohidi,, Analisis Data Kualitatif. Jakarta : UI-Press.

Moeloeng, Lexi J.. 2006. Metodologi Penelitian Kualitatif. Bandung: Remaja Rosdakarya.

Muhaimin. 2009. Manajemen Pendidikan: Aplikasi dan Penyusunan Rencana Pengembangan Madrasah. Jakarta: Prenada Media Group, 2009.

Muhaimin, Sutiah dan Sugeng Listyo. 2012. Manajemen Pendidikan. Jakarta: Prenadamedia Group.

Muhadjir, Noeng. 1989. Metodologi Penelitian Kualitatif. Yogyakarta: Raka Sarasin.

Mulyasa, E. 2012. Manajemen dan Kepemimpinan Kepala Sekolah. Jakarta: Bumi Aksara.

Murni, Wahid. 2008. Menulis Proposal dan Laporan Penelitian Lapangan, Pendekatan Kualitatif dan Kuantitatif. Malang: PPs UIN Malang.

Nasution. 1996. Metodologi Penelitian Naturalistik Kualitatif. Bandung: Tarsito.

Pearce, John A. II dan Richard B. Robinson, Jr.. 2008. Manajemen StrategisFormulasi, Implementasi dan Pengendalian. Jakarta: Salemba Empat.

Petros Pashiardis,Andreas Tsiakkiros. Strategis Planning and Education: The case of Cyprus, International Journal of Educational Management. Vol. 16 Issue: 1 August 2002. 
Permendikbud. 2005. Standar Nasional Pendidikan untuk Pendidikan Dasar dan Menengah Nomor 19 Tahun 2005.

Permendiknas 19 Tahun 2007 Tentang Standar Pengelolaan Pendidikan oleh Satuan Pendidikan Dasar dan Menengah.

Rohiat. 2009. Manajemen Sekolah; Teori Dasar dan Peraktik Dilengkapi Dengan Contoh Rencana Strategis dan Rencana Operasional. Bandung: Refika Aditama.

Rusman, 2009. Manejemen Kurikulum. Jakarta:PT Raja Grafindo Persada.

Sagala, Syaeful. 2009. Manajemen Strategik Dalam Peningkatan Mutu Pendidikan. Bandung: Alfabeta.

Sallis, Edward. 2012. Total Quality Management in Education: Manajemen Mutu Pendidikan. Jogjakarta: IRCiSoD.

Salusu, J. 2006. Pengambilan Keputusan Strategik Untuk Organisasi Publik dan Organisasi Non Profit. Jakarta: Grasindo, 2006.

Sani,Ridwan Abdullah, Isda Pramuniti, dan Anies Mucktiany. 2015. Penjamin Mutu Sekolah. Jakarta: Bumi Aksara.

Siagian, Sondang P. 2005. Manajemen Strategik. Jakarta: PT. Bumi Aksara

Singarimbun, Masri dan Sofyan Effendi. 1994. Metode Penelitian Survey. Jakarta: LP3ES.

Stoner, James A.F. \& Charles Wankel. 1996. Perencanaan dan Pengambilan Keputusan dalam Manajemen. Alih bahasa oleh Sahat Simamora. Jakarta: Rineka Cipta.

Sugiono. 2008. Metode Penelitian Kuantitatif, Kualitatif, dan R\&D. Bandung: Alfabeta.

Sukmadinata, Nana Syaudih. 2009. Metode Penelitian Pendidikan. Bandung: Remaja Rosdakarya.

Syafaruddin. 2002. Manajemen Mutu Terpadu dalam Pendidikan: Konsep, Strategi, dan Aplikasi. Jakarta: PT. Gramedia Widiasarana Indonesia. Syaifuddin, Muhammad. 2007. Manajemen Berbasis Sekolah. Jakarta: Dirjen Dikti Depdiknas. 
Tjiptono, Fandy dan Anastasia Diana. 2003. Total Quality Management. Yogyakarta: Penerbit Andi.

Umar, Husein. 2001.Strategic Management in Action, Konsep, Teori, dan Teknik Menganalisis Manajemen Strategic Business Unit Berdasarkan Konsep Michael R. Porter, Fred R. David, dan Wheelen-Hunger. Jakarta: Gramedia Pustaka Utama.

Widdah, Minnah El dkk. 2012. Kepemimpinan Berbasis Nilai dan Pengembangan Mutu Madrasah. Bandung: Alfabeta.

Yusuf, Farida. 2003. Evaluasi Program. Jakarta: Rineka Cipta Zamroni. 2007. Meningkatkan Mutu Sekolah. Jakarta: PSAP Muhammadiyah.

Zazin, Nur. 2011. Gerakan Menata Mutu: Teori \& Aplikasinya. Jogjakarta: Ar-Ruzz media.

http://subagio-subagio.blogspot.co.id/2011/01/mengukur-mutu-sekolah1.html, diakses pada tanggal 5 september 2017 pukul 21.45

Gunawan Imam, http://duniainformatikaindonesia.blogspot.com/2013/03/ciriciri-mutu-pendidikan.html

http://erfiilyas.blogspot.com/2013/11/kebijakan-mutu-persyaratan-dan.html., diakses pada tanggal 6 September 2017 pukul 22.00 


\section{Kepala Sekolah}

\section{INSTRUMEN PENELITIAN}

Bahasan :Penyusunan, Implementasi dan Evaluasi perencanaan strategis terhadap mutu pendidikan.

a. Bagaimana menurut bapak mengenai perencanaan strategic di sekolah ini?

Perencanaan strategis menurut saya, bagaimana cara sekolah ini mencapai sebuah tujuan. Cara pencapaiannya dilakukan melalui berbagai perencanaan dan program kegiatan yang dituangkan dalam Program Kerja Sekolah.

b. Apa saja yang dilakukan sebelum menyusun perencanaan strategis?

Untuk melakukan proses penyusunan, yakni saya melakukan musyawarah stakeholders terlebih dahulu, seperti orang yayasan, komite dan beberapa guru. Setelah itu saya akan memastikan apa saja yang harus disiapkan. Menganalisis eksternal sekolah dan tentunya internal sekolah.

c. Bagaimana langkah-langkah penyusunan perencanaan strategis yang dilakukan terkait dengan meningkatkan mutu pendidikan?

Untuk Langkah-langkah penyusunan perencanaan strategik yang pertama dilakukan adalah merumuskan visi, misi dan tujuan sekolah terlebih dahulu, di dalamnya ada analisis lingkungan baik internal ataupun eksternal, mengumpulkan data kondisi sekolah. Selanjutnya membentuk tim/ mengumpulkan tim untuk mengagendakan mana strategi-strategi yang akan direncanakan kemudian rencana dari tahun yang sebelumnya yang terlaksana dan yang tidak terlaksana, serta dari yang terlaksana sudah cukupkan untuk kegiatan itu dilaksanakan lagi ditahun yang akan datang.

Untuk langkah selajutnya adalah membentuk satgas/tim atau mengumpulkan tim untuk mengagendakan mana strategi-strategi yang akan direncanakan kemudian rencana dari tahun yang sebelumnya yang terlaksana dan yang tidak terlaksana, serta dari yang terlaksana sudah cukupkan untu kegiatan itu dilaksanakan lagi di tahun yang akan dating. Jadi semua waka dan kaprog saya libatkan dalam tim tersebut.

Setelah semua tim penyusun rencana strategis selesai, maka setelah itu mereka wajib melaporkan kepada saya selaku kepala sekolah. Kemudian setelah saya menganggap sudah sesuai dengan visi, misi, dan tujuan sekolah baru ditetapkanlahnya SK Kepala Sekolah. Setelah itu disosialisasikan kepada semua komponen sekolah baik secara formal maupun informal. 
d. Bagaimana proses perumusan visi, misi, dan tujuan sekolah di SMK Al-Falah Moga Pemalang?

Mengenai penyusunan visi, misi dan tujuan sekolah di SMK AlFalah ditentukan dan ditetapkan dalam rapat koordinasi yang melibatkan yayasan, dewan guru, komite. Jadi visi, misi dan tujuan merupakan hasil dari kontribusi mereka semua. Berhubung SMK ini berdiri di naungan pondok pesantren, beberapa pengasuh pondok pesantren Al-Falah pun ikut andil.

Untuk sosialisasi visi, misi dan tujuan sekolah, kita melakukan berbagai cara diantaranya kita bacakan pada waktu masa orientasi siswa baru, upacara, dipasang di tempat-tempat strategis. Contoh di depan pintu masuk sekolah dengan tujuan agar orang bisa membacanya.

e. Siapa saja yang terlibat dalam penyusunan perencanaan strategis di sekolah ini?

Penyusunan perencanaan strategis disusunan sebelum tahun ajaran baru dimulai, sekitar bulan mei-juli menjelang tahun berikutnya. Dalam penyusunannya kita melibatkan stakeholder/ keterlibatan unsur sekolah dalam tim penyusunan meliputi kepala sekolah, waka-waka, ketua tata usaha, bapak ibu guru, dan komite sekolah.

f. Program apa saja yang ditawarkan sebagai upaya peningkatan mutu pendidikan?

Pastinya untuk SMK Al-Flah sendiri sangatlah mengedapankan proses peningkatan mutu. Yang terpenting dari semuanya, SMK ini sangat mengedepankan budi pekerti, dan prinsip dari SMK ini yakni berfikir pekerjaan apa yang ada sekarang, apa yang belum ada, teknologi yang belum ada. Dengan kata lain, siswa dianjurkan untuk berimajinasi dan berinovasi. Jadi beberapa program yang sudah ada di rencana kerja sekolah disusun atas dasar itu. Harus sesuai dengan visi, misi dan tujuan.

Contohnya saja dalam bidang kurikulum, berhubung SMK Al-Falah adalah sekolah kejuruan yang berbasis Ahlussunah Waljamaah, maka diwajibkan adanya pengintegrasian nilai-nilai keagamaan dalam setiap aktivitas pembelajaran intrakurikulr maupun ekstrakurikuler.

g. Apa saja faktor pendukung dan penghambat ter-realisasinya perencanaan strategis?

Pertama saya akan menjelaskan penghambatnya terlebih dahulu, ratarata dari semua bidang, yakni belum memaksimalkan tanggung jawab yang harusnya dilaksanakan, program yang sudah terencana tidak dilaksanakan dengan maksimalkan. Maka dari itu saya sering mengarahkan bahwa untuk bekerja itu harus loyal dengan tanggung 
jawab bukan loyal dengan pimpinan. Kalau sudah menggunakan persepsi loyal dengan pimpinan, aka besar kemungkinan tidak akan maksimal tanggung jawab yang dipegangnya.

Untuk kedua, pendukung ter-realisasi nya perencanaan strategis yakni seluruh stakeholders saling mendukung, terbuka seperti masyarakat, kyai-kyai di lingkungan SMK Al-Falah, dan pondok pesantren di lingkungan sekolah ini.

h. Apakah ada kerjasama dengan pihak ekstenal sekolah dalam upaya meningkatkan mutu pendidikan?

Untuk kerjasama dengan pihak eksternal sekolah ada banyak perusahaan yang sudah bekerjasama dengan sekolah kami. Lulusan SMK Al-Falah dipastikan bisa meneruskan ke beberapa perusahaan yang sudah bekerjasama, ada sekitar 70 perusahaan.

i. Bagaimana ealuasi terhadap pelaksanaan perencanaan stratgeis di sekolah ini?

Evaluasi rencana strategis sekolah ini melibatkan seluruh stakeholders, seperti komite sebagai wadah perwakilan dari orang tua memiliki fungsi sebagai mitra sekolah dalam hal melakukan evaluasi dan pengawasan terhadap kebijakan program penyelenggaraan pendidikan di SMK AlFalah, karena hamper 75\% siswa siswi SMK disini tinggal dipondok, jadi diwakili oleh komute, dan walimurid biasanya hanya diberikan pengumuman setelahnya terkait program sekolah.

Melalui monitoring dan evaluasi, kita mendapatkan banyak feedback untuk perbaikan program kedepannya. Siklus ini dilakukan terus menerus. proses pembelajaran di kelas, kepala sekolah sebagai penanggungjawab, melakukan monitoring sebulan sekali di tiap-tiap kelas, dan kadang kepala sekolah bersama-sama dengan guru senior yang memiliki kompeten di bidang mata pelajaran tertentu. Hal ini dilakukan untuk mengetahui apakah maksimal atau tidak dalam pelaksanaannya.

Evaluasi dan monitoring lebih pada pengawasan dan penilaian yang dilakukan oleh pihak-pihak tertentu diluar sekolah. Misalnya dilakukan oleh Kandepag Kabupaten Pemalang, dan Dinas Pendidikan Kabupaten Pemalang.

j. Menurut bapak, bagaimana keadaan mutu sekolah pada saat ini dan masa yang akan dating, setelah adanya perencanaan strategis? Untuk saat ini, Alhamdulillah mutu SMK Al-Falah semakin meningkat dan diakui oleh masyarakat sekitar. Dengan bukti peningkatan siswa yang semakin meningkat, maka pastinya pembangunan sekolah pun 
semakin luas. Dan ada lagi, SMK Al-Falah mendapatkan The Best Leading Vacational School Quality .

\section{Wakil Kepala Sekolah}

\section{(Waka Kurikulum, Waka Kesiswaan, Waka Humas, Waka Sarpras)}

a. Bagaimana menurut bapak mengenai perencanaan strategis di sekolah ini?

1) Waka Kurikulum

Perencanaa strategis, untuk di SMK Al-Falah ini yang tertulis yakni Program Kerja Sekolah, itu adalah rencana satu tahun apa saja yang dilakukan. Menurut saya sangat penting adanya perencanaan tersebut, karena pastinya dengan adanya sebuah perencanaan, tujuan yang kita ingin capai, akan berjalan, ya walaupun terkadang pelaksanaannya ada hambatan.

2) Waka Humas

Perencanaan strategis di sekolah sangat diperlukan. Kalau memang ingin sekolah bagus, bermutu, maka pasti harus merencanakan program yang mendukung meningkatnya mutu sekolah.

3) Waka Kesiswaan

Penyusunan perencanaan strategis menurut saya sangat penting sekali, apalagi untuk bidang kesiswaan sendiri. Contohnya saja, pertama tentang penerimaan siswa baru, program kegiatan di sekolah untuk siswa, dan masih banyak lagi hal-hal untuk pengembangan program kerja bidang kesiswaan.

b. Bagaimana langkah atau proses dalam menyusun perencanaan strategis?

1) Waka Kurikulum

Penyusunan perencanaan strategis disusunan sebelum tahun ajaran baru dimulai, sekitar bulan mei-juli menjelang tahun berikutnya. Dalam penyusunannya kita melibatkan stakeholder/ keterlibatan unsur sekolah dalam tim penyusunan meliputi kepala sekolah, waka, ketua tata usaha, bapak ibu guru, dan komite sekolah.

Contohnya saja saya dalam bidang kurikulum, saya akan menanyakan kepada masing-masing guru bidang studi kritik dan saran untuk program apa yang ingin dilaksanakan untuk satu tahun kedepan terkait dengan pengembangan kurikulum atau kegiatan belajar mengajar

2) Waka Humas 
Penyusunan rencana strategis, dalam hal ini program kerja sekolah, dilakukan pada akhir tahun akademik menuju awal tahun akademik. Khususnya dalam bidang humas, saya membuat program kerja berdasarkan hasil evaluasi rencana tahun sebelumnya. Apa yang belum terlaksana dan apakah ada program yang ingin ditambah, tentunya dengan jalan musyawarah. Lalu setelah itu saya berikan kepada kepala sekolah untuh di koreksi, tentunya di sahkan juga.

3) Waka Kesiswaan

Untuk penyusunan rencana strategis, tentunya arahan dari pimpinan untuk membuat kepanitiaan atau tim. Setelah itu, pimpinan membebaskan tim untuk membuat rencana atau program apa saja yang akan dilaksanakan untuk setahun kedepan. Tentunya dengan melihat catatan evaluasi rencana tahun lalu. Setelah itu, setelah tim merumuskan, akan dikoreksi oleh pimpinan.

c. Bagaimana bapak melaksanakan perencanaan strategis, adakah faktor penghambat dan pendukung?

1) Waka Kurikulum

Untuk pelaksanaannya sendiri, tentunya tidak jauh dari apa yang sudah direncanakan. Jika tahun lalu, ada program yang masih belum maksimal pelaksanaannya, tentunya kita perbaiki. Jika ada program baru yang direncanakan, tentunya kita akan memaksimalkan.

Tapi tetap saja, banyak faktor penghambat yang terjadi dalam pelaksanaanya, salah satu contoh, terkait dengan pembelajaran, siswa disini dilihat dari segi kualitas, bisa bersaing dengan sekolah lain khususnya di wilayah Pemalang, namun karena kurangnya motivasi siswa disini, maka hasilnya terkadang kurang maksimal.

2) Waka Humas

Implementasi rencana strategis di sekolah ini, sangatlah terbuka. Contohnya program untuk meningkatkan kualitas guru disini saya selalu mengikutkan guru-guru untuk diklat, workshop, dan seminar. Serta biasanya setelah saya ada workshop atau seminar yang saya ikuti, saya akan share kepada semua warga sekolah terutama guru-guru dan tenaga kependidikan yang lainnya. 
Namun kendala tetap pada keuangan. Harus pintar menggunakan sumberdaya yang ada di sekolah ini.

\section{3) Waka Kesiswaan}

Pelaksanaan program yang sudah direncanakan, khususnya di SMK Al-Falah ini sangatlah bebas, kepala sekolah memberikan kebebasan kepada kami selaku waka kesiswaan.

Untuk mencapai mutu sekolah, seolah ini sangat terbuka, contohnya saja dalam bidang kegiatan lomba-lomba atau ekstrakurikuler. Kepala sekolah memberikan wewenang kepada guru, dan siswa. Kendala terbesar salah satunya adalah keuangan. Karna sekolah ini swasta jadi harus pintar untuk mencari dana sendiri.

d. Apakah ada evaluasi terhadap program strategis yang telah bapak laksanakan?

1) Waka Kurikulum

Evaluasi untuk kurikulum sendiri tentu adanya, salah satu komponen yang wajib dievaluasi adalah berkenaan dengan proses dan hasil belajar siswa. Hasil-hasil evaluasi sendiri nantinya bisa digunakan oleh para pemegang kebijakan pendidikan dan para pengembang kurikulum dalam menetapkan sistem pendidikan. Dan jga dapat digunakan oleh guru-guru, kepala sekolah, dan para pelaksana pendidikan lainnya dalam memahami dan membantu perkembangan peserta didik, memilih bahan pelajaran, memilih metode, dan alat bantu pelajaran, cara penilaian serta dasilitas pendidikan lainnya.

2) Waka Humas

Untuk evaluasi, pasti diadakan, sebulan sekali ada, dan akhir dari evaluasi dilaksanakan pada akhir tahun ajaran. namun teguran dan masukan dari kepala sekolah ataupun dari sesama guru, disini juga ada, itu kita anggap evaluasi.

3) Waka Kesiswaan

Evaluasi program kerja di skolah ini dilakukan satu tahun diakhir tahun, biasanya seperti itu, dan bisa saja tiba-tiba diadakan rapat terkait program sekolah, seperti rapat koordinasi

e. Menurut bapak, bagaimana keadaan mutu sekolah pada saat ini dan masa yang akan datang, setelah adanya perencanaan strategis?

1) Waka kurikulum

Untuk saat ini, sekolah kami dari segi akreditasi, sekolah kami mendapatkan nilai A. untuk saat ini sekolah kami sedang merencanakan untuk kedepannya, yakni terpenuhinya sarana 
dan prasarana untuk kegiatan belajar mengajar, mengingat jumlah siswa yang meningkat pertahunnya. Dan terpenuhinya guru yang berkualitas dengan linear dengan mata pelajaran yang diajarkan.

\section{2) Waka Humas}

Dalam bidang humas, tentunya sekolah kami sudah merencanakan kedepannya, agar mutu sekolah kami semakin meningkat, yakni penambahan guru produktif dan normative, penambahan tenaga kependidikan. Karena kita mengharapkan sekolah kami memenuhi 8 standar nasional pendidikan.

\section{3) Waka Kesiswaan}

Untuk meningkatkan mutu pendidikan, salah satu yang berpengaruh yaitu bagaimana kondisi siswa, oleh sebab itu perlu adanya penerimaan calon siswa baru yang selektif dengan menerapkan sistem penyaringan antara penelusuran minat dan motivasi, potensi kecerdasan, akademik dan non akademik, dan terutama untuk di SMK Al-Falah adalah siswa yang memiliki minat untuk mendalami agama, berakhlak mulia, dan disiplina, contohnya saja kepala sekolah memberikan wewenang kepada guru, jika ada siswa yang melanggar beliau serahkan kepada kami. Tapi tetap saja semua masih dalam pengawasan bapak kepala sekolah. 


\section{PROGRAM KERJA SEKOLAH TAHUN PELAJARAN 2016/2017}

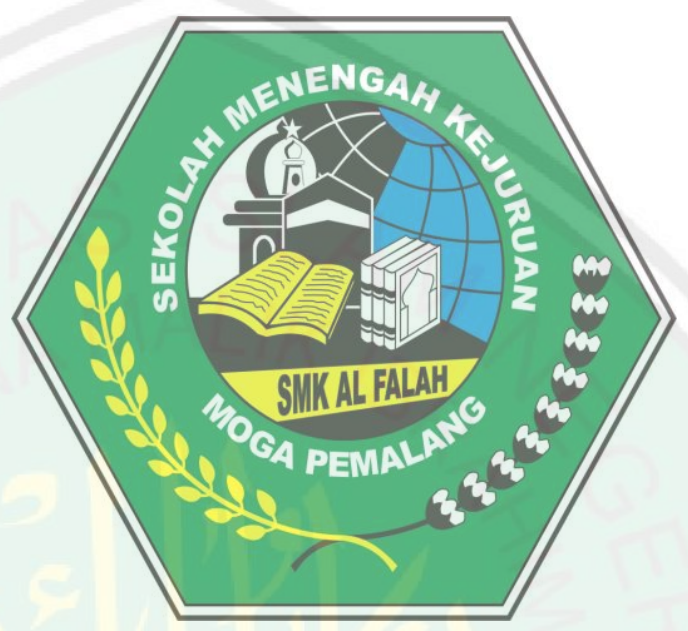

DISUSUN OLEH:

SMK AL FALAH MOGA

Alamat:

Jl. Raya Moga Guci Km 0,5 Banyumudal - Moga 52354 Telp ( 0284 ) 583371 / HP 081911530012 


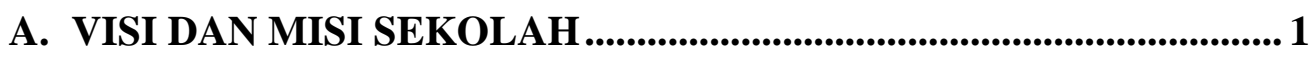

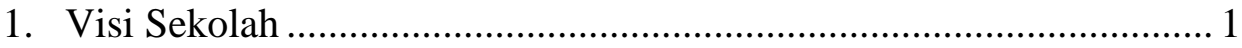

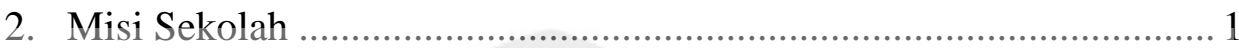

B. TUJUAN SEKOLAH......................................................................... 1

C. PROGRAM KERJA SMK AL FALAH ................................................... 1

1. Program Unggulan Lokal ................................................................. 1

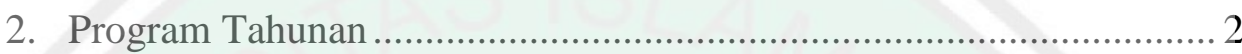

4.1 Peningkatan Manajemen Sekolah ............................................ 2

4.2 Pengembangan Kurikulum...................................................... 2

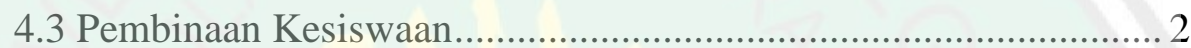

4.4 Pengembangan fasilitas/ Sarana prasaran ................................... 2

4.5 Pengembangan Ketenagaan/Personalia......................................... 3

3. PERINCIAN PROGRAM KERJA

A. Program Unggulan Lokal ............................................................ 3

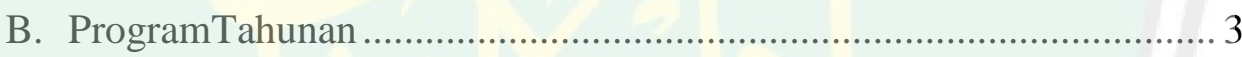

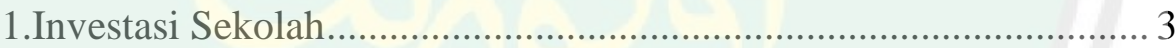

2.Pengadaan Perabot/Mebeler ............................................................. 3

3.Pengadaan Peralatan dan bahan Praktek ........................................... 4

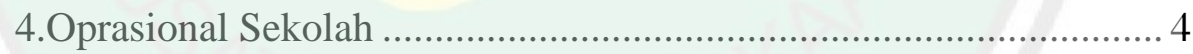

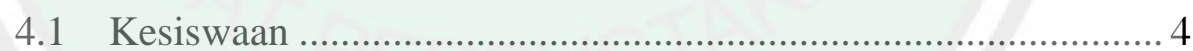

4.2 Pengembangan Kurikulum................................................... 5

4.3 Kepegawaian .............................................................. 5

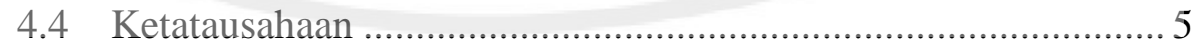

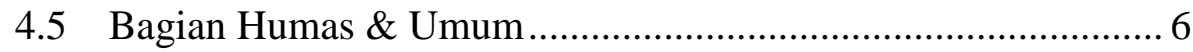

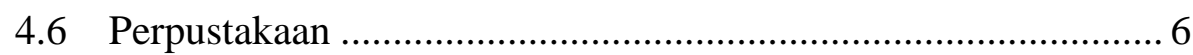

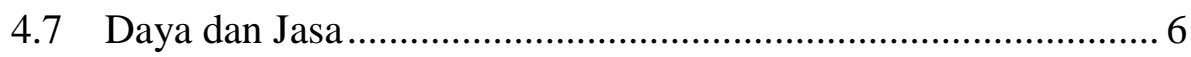




\section{PROGRAM KERJA \\ SMK AL FALAH MOGA \\ TAHUN PELAJARN 2016/2017}

\section{A. Visi dan Misi Sekolah}

\section{Visi Sekolah:}

Membangun Sumberdaya Manusia yang beriman, bertaqwa trampil mandiri dan profesional

2. Misi Sekolah :

2.1 Meningkatkan keimanan dan ketaqwaan kepada Allah Swt bagi sivitas smk Al Falah Moga.

2.2 Terjalin hubungan yang harmonis, Seimbang dan Kesinambungan dalam hubungan manusia dengan manusia, manusia dengan tuhannya, dan manusian dengan alam sekitarnya.

2.3 Membekali pengetahuan, sikap dan ketrampilan pada siswa untuk hidup mandiri dan profesional.

2.4 Menumbuhkembangkan sikap dan prilaku kompetatif dikalangan siswa agar hidup sehat dan berkualitas

B. Tujuan Sekolah

1. Mewujudkan SMK AL-Falah sebagai lembaga pendidikan dan kepelatihan yangmampu mengoptimalkan sumber daya manusia dan sumber daya alam

2. Membekali peserta didik yang mempunyai etos kerja dengan standar Nasional

3. Memanfaatkan sumber daya manusia sumber daya alam, dan sumber daya modal yang ada untuk mengoptimalkan penyelenggaraan pendidikan

4. Terwujud penyelenggaraan pendidikan Pondok Pesantren dengan pendidikan Formal sebagai model dalam mempersiapkan peserta didik menjadi sumber daya manusia yang berkualitas.

C. Program Kerja SMK Al Falah Moga

1. Program Unggulan Lokal ( Pertanian Dan Peternakan )

Wilayah kecamatan Moga menjadi salah satu kecamatan sentral Agropolitan di Kab. Pemalang. Agropolitan WALIKSARIMADU merupakan program pemerintah kabupaten Pemalang dalam mengembangkan pertanian, peternakan dan perikanan. Potensi ini menjadikan dasar SMK Al Falah memilih program unggulan dibidang pertanian dan peternakan.

\section{Program Tahunan}

\subsection{Peningkatan Manejemen Sekolah}

a. Pembagian tugas dan fungsi Guru dan Tenaga kependidikan

b. Menyusun program kerja tahunan 
c. Akriditasi JurusanTata Busana dan Budidaya tanaman

d. Rapat rutin untuk pembinaan guru dan tenaga kependidikan

e. Monitoring kegiatan KBM

f. Evaluasi secara berkala kegiatan KBM

g. Menjalin kerja sama dengan DU/DI

\subsection{Pengembangan kurikulum}

a. Penyusunan Kurikulum KTSP Spektrum

b. Rencana Pembelajaran

c. Penyusunan RPP bagi guru mapel

d. Penjadwalan KBM

e. Pelaksanaan Ulangan bersama, tengah semester, dan semester

f. Analisis hasil evaluasi pelaksanaan KBM

\subsection{Pembinaan Kesiswaan}

a. Pembentukan pengurus OSIS

b. Pembinaan kegiatan OSIS

c. Pelaksanaan kegiatan Upacara hari Senin, Hari- hari besar Nasional

d. Bakti sosial OSIS

e. Kegiatan ektra kurikuler ( Pramuka, olah raga, dan kesenian )

f. Kegiatan Lomba- lomba ( mapel, Olah raga, seni, Agama, LKS )

2.4 Pengembangan fasilitas / Sarana prasarana

a. Penambahan ruang kelas baru

b. Penambahan MCK/ WC

c. Pengadaan peralatan praktek ( Tata Busana, Budidaya Tanaman, dan TMO)

d. Pengadaan bahan praktek

f. Pengadaan laboraterium komputer

g. Pengadaan buku mapel Normatif, adaftif, dan produktif

h. Penataan halaman sekolah

i. Kegiatan K3 di lingkungan Sekolah

j. Pembangunan sarana ibadah ( musholah)

2.5 Pengembangan Ketenagaan / Personalia

a. Penambahan guru produktif dan normati

b. Penambahan tenaga kependidikan

c. Pengiriman guru dalam kegiatan MGMP

d.Pengiriman Diklat peningkatan kompetensi bagi guru dan tenaga kependidikan 


\section{PERINCIAN PROGRAM \\ TAHUN PELAJARAN 2016/2017}

A. Program Unggulan

1. Budidaya Jamur Tiram

2. Peternakan sapi Potong

3. Pengolahan Bio gas

4. Pengolahan Pupuk Bogasi

B. Program Tahunan

1. Investasi Sekolah

2.1 Ruang kelas Barul

2.2 Pembuatan MCK/WC

2.3 Penataan halaman

2.4 Pengadaan computer

2.5 Pengadaan Peralatan Praktek

2.6 Pembangunan Mushola THP 1

2.7 Pengadaan mesin Potong Rumput

2. Pengadaan Perabot/ Mebeler

$2.1 \mathrm{Meja} /$ kursi Siswa 1

2.2 Meja/kursi Siswa 2

2.3 Meja kursi Guru

2.4 Pengadaan Papan Tulis

2.5 Almari dan Rak Arsip

3. Pengadaan Alat Dan Bahan Praktek.

1. Program Tata Busana

1.1. Penambahan alat praktek ( Mesin Jahit )

1.2. Perawatan Alat

1.3. Pengadaan Bahan Praktek

2. Program Budidaya Tanaman

2.1. Rumah Jamur Tiram

2.2. Gudang Penyimpan Alat Praktek

2.3. Penambahan alat Praktek

2.4. Pengadaan Bahan Praktek

3. Program Otomotif

3.1. Pembangunan Ruang Bengkel Otomotif

3.2. Penambahan Alat Praktek

3.3. Pengadaan Bahan Praktek 


\section{Oprasional Sekolah}

4. 1. Kesiswaan

egiatan Intrakurikuler

Kegiatan Ekstrakurikuler

a. Ketrampilan Bahasa Inggris

b.Ketrampilan Bahasa Korea

c. Ketrampilan Bahasa Mandarin

d. Pencak Silat

e. Kepramukaan

Kegiatan lomba

a. Lomba Mapel Normatif

b. Lomba Olah raga

c. Lomba MTQ \& Tartil

d. Lomba Mapel Produktif

Kegiatan pameran

Kegiatan PHBN/PHBI

Kegiatan perpisahan

Penghargaan Siswa berprestasi

4. 2. Pengembangan Kurikulu

1. Penyusunan KTSP Spektrum

2. Penyusunan RPP

3. Ujian Tengah Semester

4. Ujian Semester

5. PSG/PKL

6. Pengayaan kelas XII

7. Ujian Praktek

8. Ujian Nasional

9. Ujian Sekolah

10. Pencetakan raport

11. Tugas Akhir

12. Persiapan Akriditasi

13. Pelaksanaan akriditasi

14. MGMP Mapel 


\section{3. Kepegawaian}

1. Honor Guru

2. Honor tenaga kependidikan

3. Tunjangan masa kerja

4. Lembur

5. Transport Guru/karyawan

6. Insentif tugas tambahan

7. Peningkatan Kompetensi Guru

8. Pelatihan Guru Produktif

9, Pelatihan Guru Normatif

10, Pelatihan Guru adaftif

11. Seragam guru \& staff

12. THR

13. Home Visit

4.4.Ketatausahaan

1. ATK

2. Penggandaan/Fotocopy

4. Filling kabinet 4 laci

5. Papan data

6. Flas disck

4. 5. Bagian Humas \& Umum

1. Rapat wali murid

2. Rapat dewan guru

3. Rapat K3S

4. Rapat koordinasi Tk. Kab.

5. Rapat Tk. Propinsi

6. Rapat Tk. Nasional

7. Jamuan tamu

8. Sosial dan partisipasi

9. Iuran K3S

4. 6. Perpustakaan

1. Pengadaan buku

2. Pengadaan buku produktif

3. Rak buku

4. Administrasi perpustakaan

4.7. Daya dan Jasa

1. Listrik dan air

2. Telepon

3. Jasa

Moga, 13 Juli 2017

Kepala Sekolah

Drs. Rujito Dw 
PROGRAM KEGIATAN KESISWAAN

SMK ALFALAH MOGA

TAHUN PELAJARAN 2016/2017

\begin{tabular}{|c|c|c|c|c|}
\hline NO & \begin{tabular}{|c|} 
NAMA KEGIATAN \\
\end{tabular} & $\begin{array}{c}\text { WAKTU } \\
\text { PELAKSANAAN }\end{array}$ & $\begin{array}{r}\text { PELAKSANA } \\
\text { KEGIATAN }\end{array}$ & CATATAN \\
\hline 1. & $\begin{array}{l}\text { MOPD ( Masa Orientasi Siswa } \\
\text { Baru ) }\end{array}$ & Juli 2016 & $\begin{array}{ll}- & \text { Guru } \\
- & \text { OSIS } \\
- & \text { IPNU./IPPNU } \\
- & \text { PKS }\end{array}$ & U \\
\hline 2. & $\begin{array}{l}\text { PTA ( Penerimaan Tamu } \\
\text { Ambalan ) }\end{array}$ & Juli 2016 & $\begin{array}{ll}\text { - } & \text { Bantara } \\
\text { - } & \text { Laksana } \\
\text { - } & \text { Pembina Pramuka }\end{array}$ & 15 \\
\hline 3. & $\begin{array}{l}\text { Peringatan } 17 \text { Agustus 1945: } \\
-\quad \text { Lomba-lomba } \\
\text { - } \text { Upacara } \\
\text { - } \quad \text { Karnaval }\end{array}$ & Agustus 2016 & $\begin{array}{ll}\text { - } & \text { Semua Peserta Didik } \\
& \text { Smk Alfalah Moga } \\
\text { - } & \text { Guru }\end{array}$ & $\frac{2}{2}$ \\
\hline 4. & $\begin{array}{l}\text { Peringatan Hari Raya Idul Adha: } \\
\text { - } \quad \text { Pembagian Kambing } \\
\text { Kedesa-desa }\end{array}$ & September 2016 & $\begin{array}{ll}- & \text { OSIS } \\
- & \text { IPNU/IPPNU }\end{array}$ & 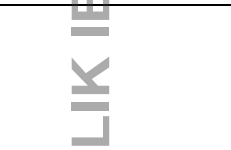 \\
\hline 5. & LKS tingkat Provinsi & September 2016 & $\begin{array}{l}\text { - Semua Program } \\
\text { Keahlian }\end{array}$ & 2 \\
\hline 6. & LDK & Oktober 2016 & - OSIS & 4 \\
\hline 7. & $\begin{array}{l}\text { Peringatan Tahun Baru Islam } \\
1437 \text { H : } \\
\text { - } \quad \text { Pawai Taaruf } \\
\text { - Pengajian }\end{array}$ & Oktober 2016 & $\begin{array}{ll}- & \text { OSIS } \\
- & \text { IPNU/IPPNU } \\
- & \text { PKS }\end{array}$ & 4 \\
\hline & & & & $\begin{array}{l}\geq \\
\frac{1}{2} \\
\frac{1}{2} \\
\frac{2}{2} \\
\frac{2}{2}\end{array}$ \\
\hline
\end{tabular}




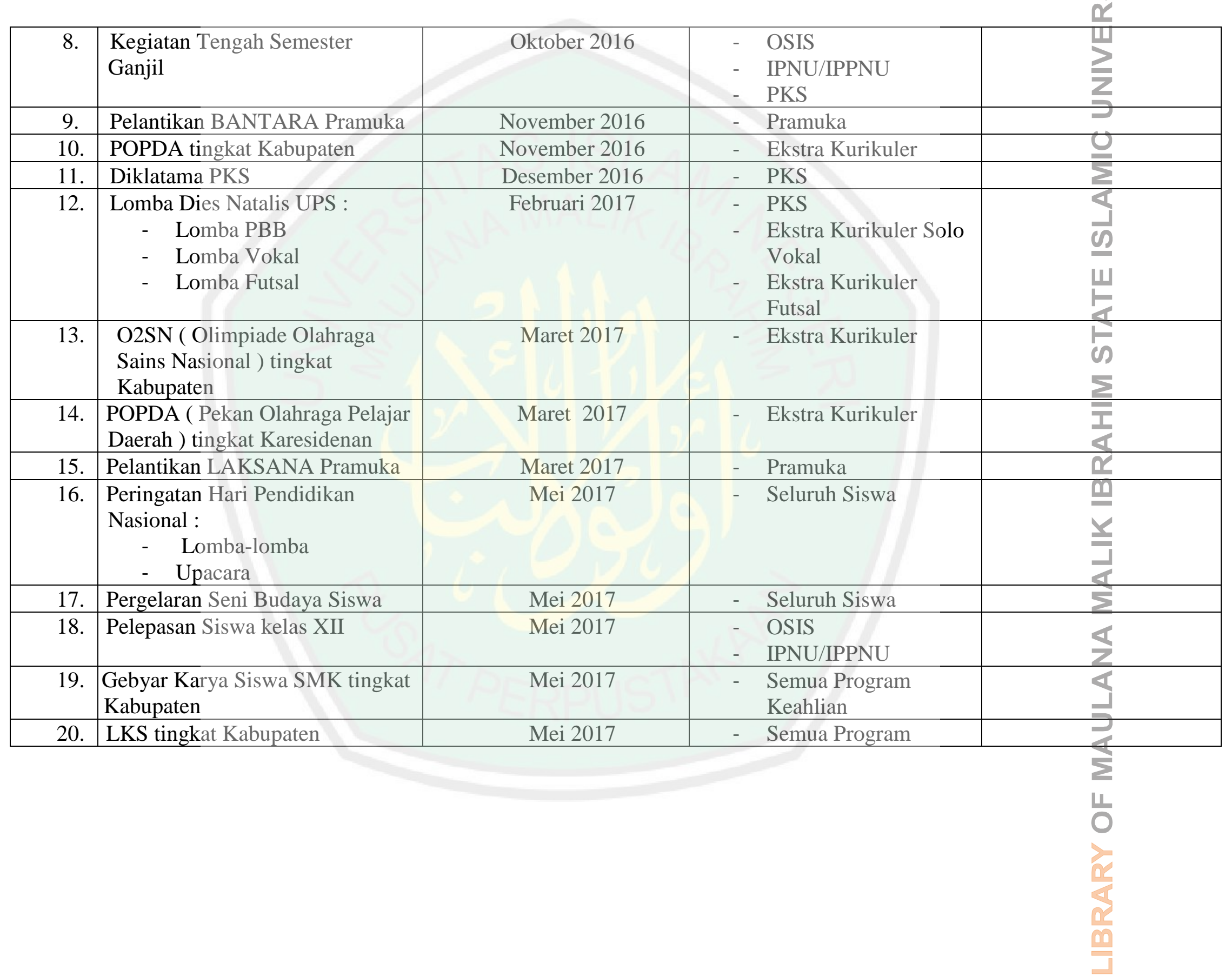




\section{Lampiran 1. Dokumen SMK Al-Falah Moga Pemalang}

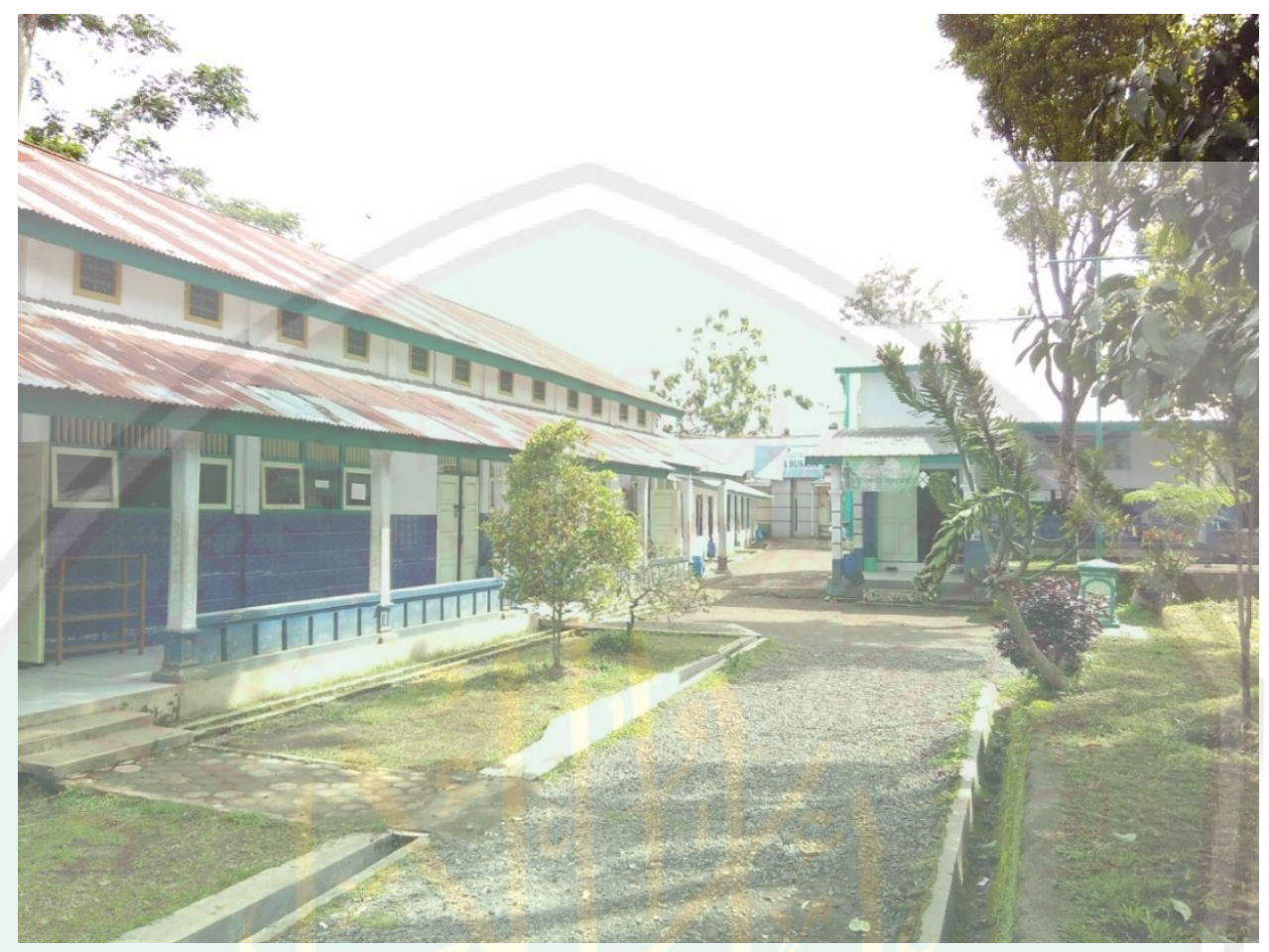

Foto Gedung SMK Al-Falah Moga Pemalang

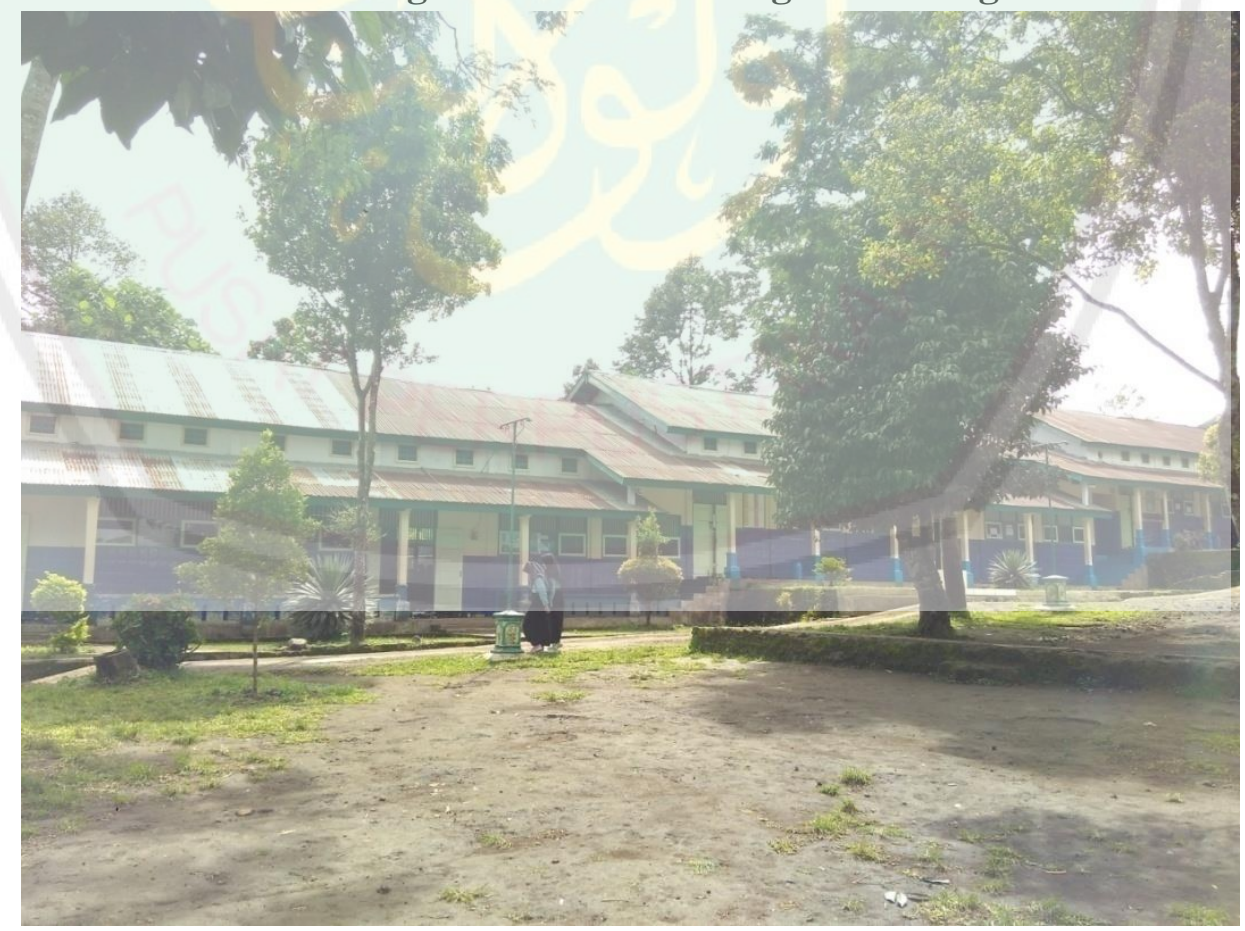


Foto kegiatan siswa SMK Al-Falah (Perpustakaan)

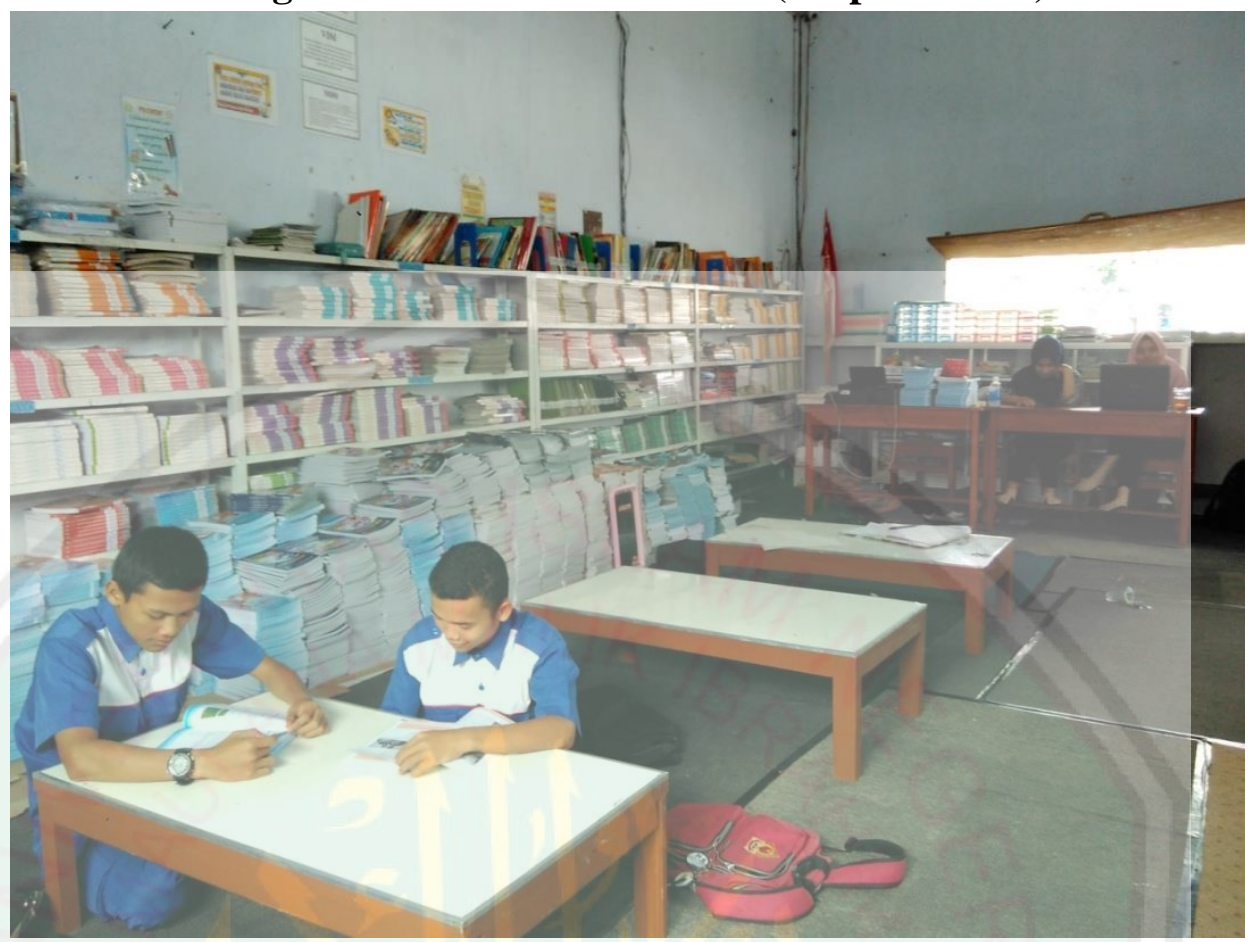

Foto beberapa prestasi yang pernah diraih SMK Al-Falah

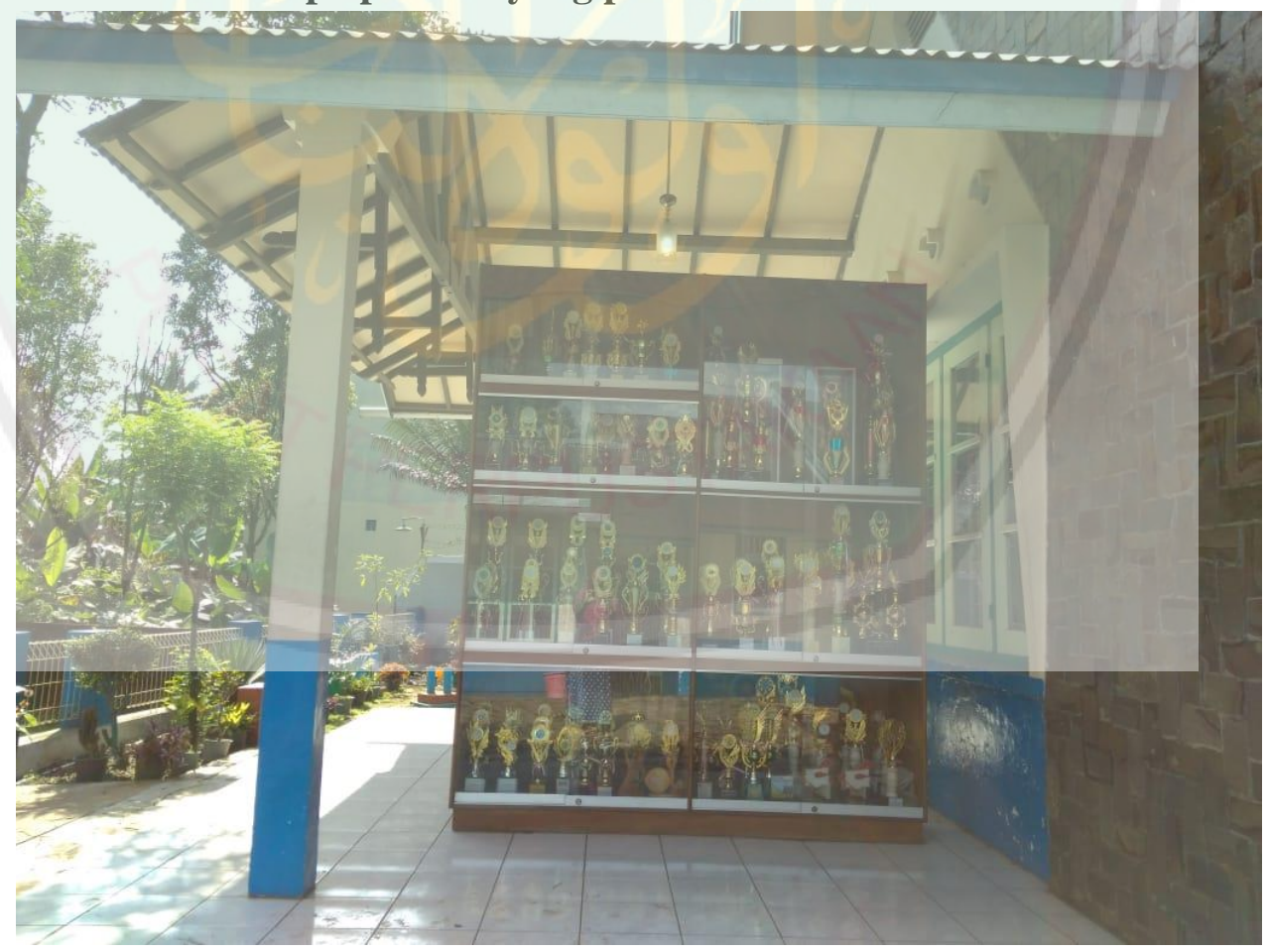


Foto Visi, Misi SMK Al-Falah Moga (Gerbang depan sekolah)

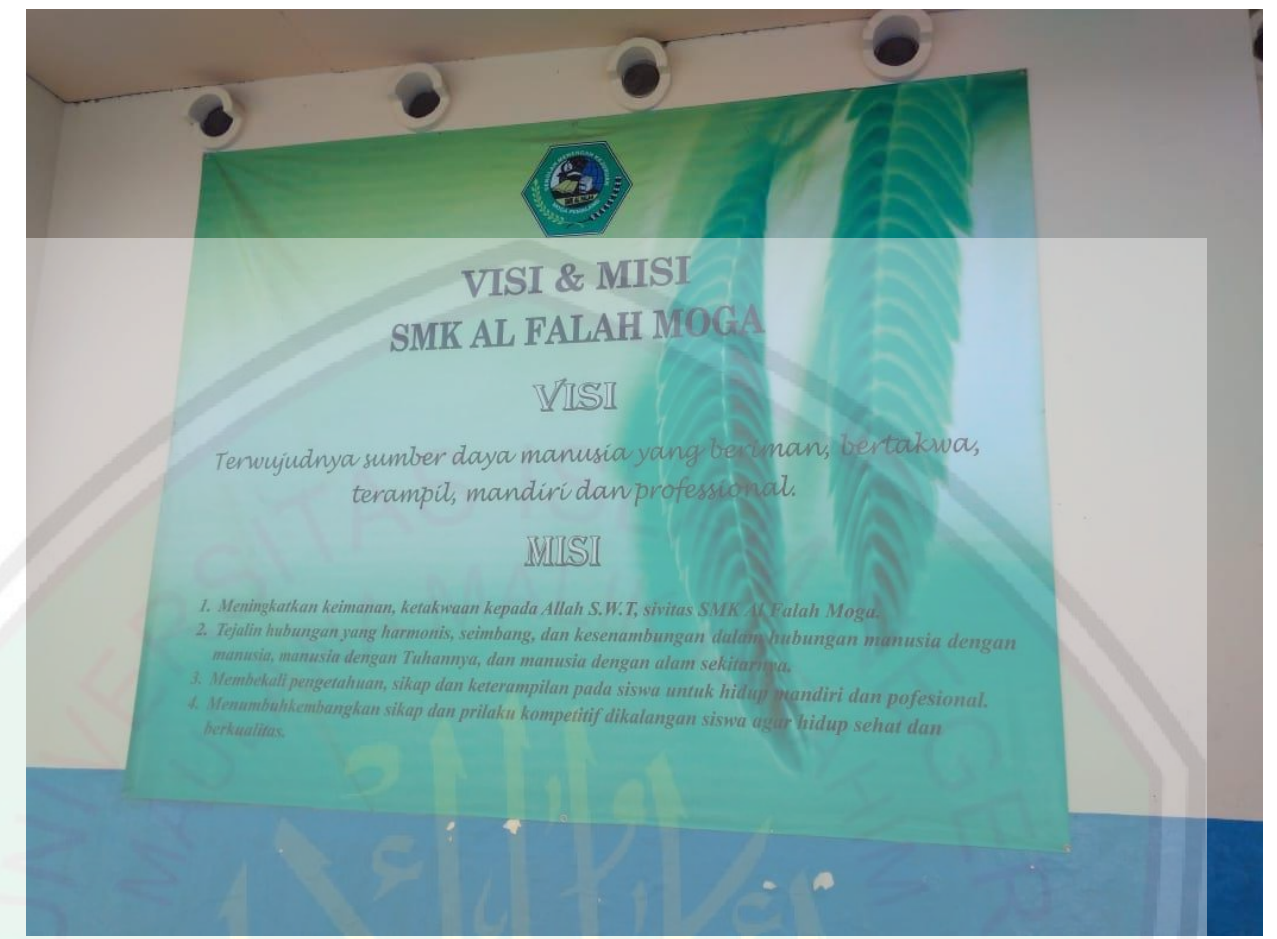

Foto Visi, Misi SMK Al-Falah

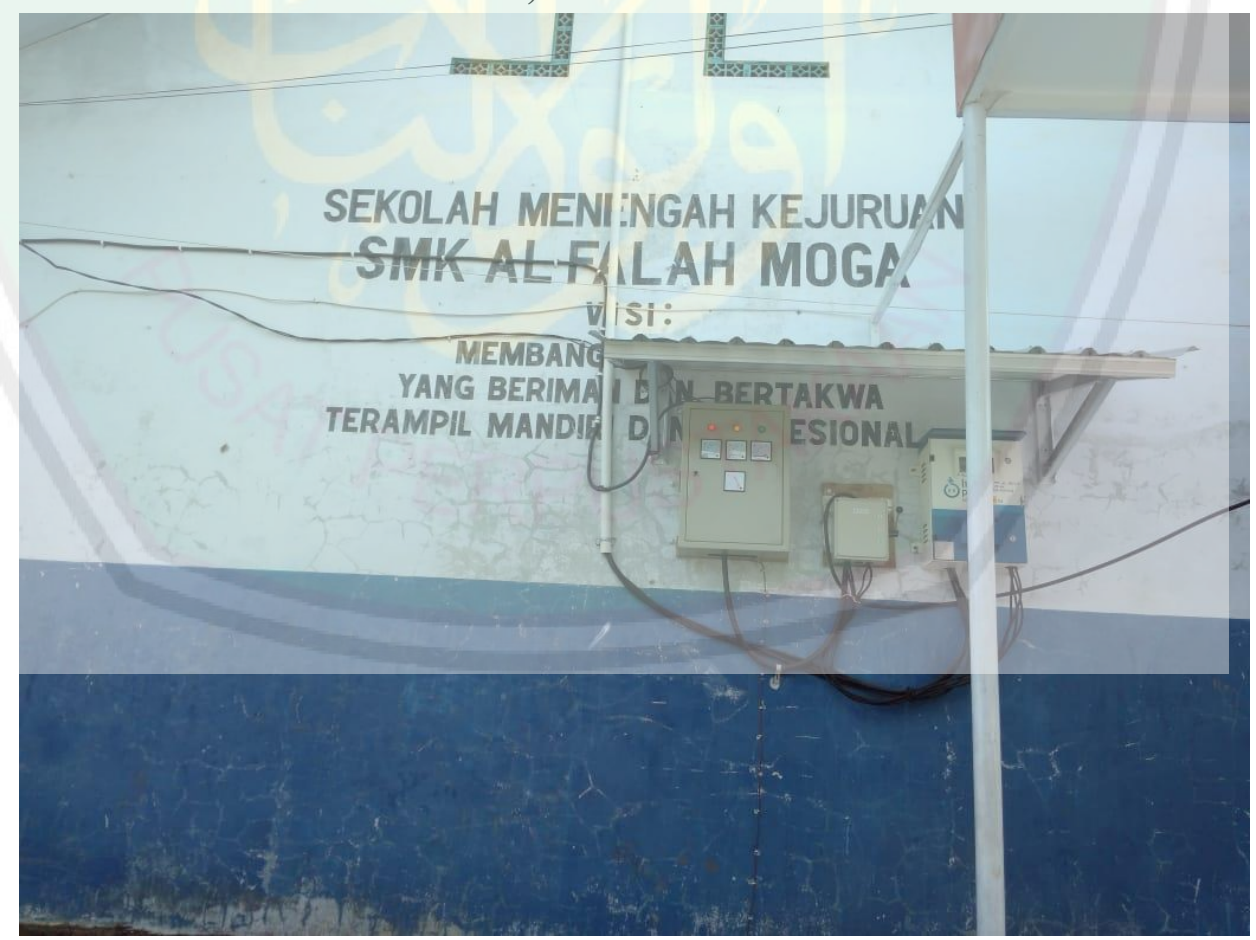

